\title{
The Cambridge/Bradford Boeotian Expedition: the First Four Years
}

\author{
J. L. Bintliff \\ Bradford University \\ Bradford, England
}

\author{
A. M. Snodgrass \\ Cambridge University \\ Cambridge, England
}

\begin{abstract}
This is a preliminary report (the first substantial publication to appear) on the first four seasons' work of an archaeological survey project in Boeotia, central Greece, reinforced by the results of a further study season. After a brief general consideration of survey strategies, the article concentrates on the specific conditions of the sample area chosen in western Boeotia. A full account is given of the field procedures adopted in the opening season (1979), with the changes introduced in subsequent years. The findings, based on the $21.5 \mathrm{sq} \mathrm{km}$ covered so far in this high-intensity survey, are then reported period by period, and a summary account of the nonarchaeological studies undertaken in collaboration with the expedition is appended. The article is supported by full tabulation of sites and periods.
\end{abstract}

\section{Introduction: the Crisis in Greek Archaeology}

To understand the true state of archaeology in Greece in the 1970s and 1980s is to understand the strength of the case for conducting archaeological survey there. One should not paint too sensational a picture of its plight, but it is nevertheless a serious one. Controlled excavations, conducted for research purposes and without pressure of time, have come to compose only a small minority of the operations in Greece: the steadily increasing pace of urban and rural development, coupled with stricter legislation about antiquities, has imposed ever greater burdens on the Greek Archaeological Service. In the city of Athens alone, there were 87 official excavations recorded in 1967. The same problems, on a smaller scale, are growing up in each of the modern towns of Greece that are located on the sites of ancient cities: Argos, Sparta, and Thebes are only the most conspicuous examples. The growth of multi-storey building, with its need for deep foundations, means that the bulldozer inevitably disturbs ancient remains. The resultant operations of the archaeologist are conducted, as a rule, within a cramped space, under great pressure, and at an inconvenient time. Each year will see the publication of scores of short reports on small, necessarily uncoordi- nated sites. Nor is the problem restricted to the cities: in the countryside, the building of highways and aqueducts, factories and holiday villas, and the laying of pipe-lines and power-cables give rise to many similar emergency excavations. Whether or not a final report can be produced, there are always the finds to accommodate; which observation brings us to the second great area of crisis, the overloading of the Greek museums. Exhibition-space

Note. The authors wish to express their warm thanks for the support that many have given to a project whose long-term value may not always have been immediately apparent. We are especially grateful to successive Ephors and Epimeletes of Antiquities at Thebes: Drs. O. Alexandri, A. Andreiomenou, and K. Dimakopoulou-Papantoniou; to Mr. D. Kollias, the Grammateus, and the other inhabitants of our base village of Mavrommati for much help and hospitality; to Dr. H. W. Catling and successive Assistant Directors of the British School at Athens for the handling of our official relations; and to our American and British colleagues conducting other surveys in Greece, notably the Ohio Boeotia Project, the Argolid Exploration Project, and the Megalopolis Survey. 
cannot possibly be enlarged at a rate that will keep pace with the new finds pouring in; even storage-space is near bursting-point in many places. The Foreign Schools do their best to help out with the first of these two great problems in their established site-areas, but in so doing they inevitably aggravate the second.

What is to be done? Clearly archaeologists in Greece must revise their priorities and strategies, as they have already had to do in other countries, such as Britain. The high premium on beautiful objects and sensational discoveries, which has been an unquestioned feature of Classical archaeology for more than a hundred years, must no longer take precedence. Field techniques must instead be designed, deliberately, to produce a higher ratio of new knowledge to new objects. The opportunity may also be taken to adjust the balance of field archaeology in other ways: e.g., to correct long-established biases of region and period, and the equally pronounced bias towards urban and away from rural settlement. Again, if there is a lesson to be drawn from the long and dispiriting controversies that have arisen over the stratification of past excavations in Greece, it is that the essentially destructive nature of all excavating activity carries great dangers with it. A nondestructive technique, whose results can, if necessary, be checked by re-examination of the same ground (rather than, at best, of another part of the same site), has an obvious advantage in this respect.

An intensive, all-period archaeological survey of a well-chosen region would seem, to us at least, to meet almost all of the aims listed above. It produces a body of finds, certainly, but in modest quantity, and of a quality that will not make great demands on museum exhibition-space. Yet these same finds can form the basis for a range of historical inference that is both broad and deep. It will inevitably throw at least as much light on rural as on urban settlement, and probably more, whereas today the essential urban bias of excavationwork is being greatly intensified by the increase in the kind of rescue work in the centers of ancient settlements, which was described above. Of course survey, too, has its "rescue" aspect in the Greek landscape of today. What it may save from extinction is not so much the physical fabric of ancient remains, as the actual evidence for settlements having existed in certain places. It is by now a common experience in modern survey-work to find that surface remains, not spectacular enough to demand a stay of execution and an emergency excavation, are being destroyed between one season and the next by construction works or quarrying, or by natural processes that have often been accelerated by such man-made initiatives.

One of the co-directors of our project, J. L. Bintliff, had conducted during the 1970s a series of individual regional studies in the Greek mainland and islands, concentrating especially on those aspects specified in the title of the work incorporating the results, Natural Environment and Human Settlement in Prehistoric Greece (1977). These operations both produced their own substantial results and pointed the way for an extension of their basis. In particular, if the chronological range were to be enlarged to cover the whole of antiquity, or even perhaps the whole human past, in a given region, then a team of some size was clearly going to be needed. The archaeological range alone would demand a combination of expertise not to be found in one person's competence. Several of the nonarchaeological aspects, such as vegetational history, involved specialists of their own; the study of settlement-patterns, if brought down to very recent times, would demand anthropological as well as historical experience; and the basic work of field-walking, if it was to be extended over an area of significant size without loss of intensity, would require many pairs of feet. Meanwhile, such lessons were in any case being learned and applied by others in different parts of the Greek landscape. The pioneering work of the University of Minnesota Messenia Expedition in the 1960s, though theirs was not an intensive survey, has served as a paradigm for all subsequent work of this kind in Greece. The full publication of their work $^{1}$ was followed a decade later by the next full-length survey publication from Greece, the British Melos survey. ${ }^{2}$ But there are major differences of approach between the two. The Minnesota project covered, by Aegean standards, a huge area (about $3,700 \mathrm{sq} \mathrm{km}$ ), but, as the title of the volume indicates, with a concentration on one period. The Melos project started with an area of less than $3 \%$ of that size and the staff then surveyed intensively a $20 \%$ sample, chosen on a "systematic random" basis; but it did so for all periods of the past. There are important issues of principle and method involved here, to which we must return. Meanwhile, briefer publications had been appearing, which showed that, at any rate, American and British archaeologists working in Greece were becoming converted to survey in its broad sense; both team and oneman projects were involved. Some of the surveys followed in a general way the aims of the Minnesota team, by carrying out extensive survey, usually concentrating on the earlier periods. Under this heading we may place

1. W. A. McDonald and G. R. Rapp, Jr., eds., The Minnesota Messenia Expedition: Reconstructing a Bronze Age Regional Environment (University of Minnesota Press: Minneapolis 1972).

2. C. Renfrew and M. Wagstaff, eds., An Island Polity: the Archaeology of Exploitation in Melos (Cambridge University Press: Cambridge 1982). 
the surveys in Euboea ${ }^{3}$ and in Crete,${ }^{4}$ all of these reported in the Annual of the British School at Athens. J. Wiseman's volume on the Corinthia ${ }^{5}$ covered a wider chronological range. Others were adopting an intensive approach more akin to that of the Melos project: these included the Ayiopharango valley survey (in which Bintliff was again involved), ${ }^{6}$ and L. V. Watrous' monograph on the Lassithi plain, ${ }^{7}$ both surveys again located in Crete. Three large current projects have also adopted the "intensive" strategy: the year 1981 saw the opening of the Megalopolis survey conducted by the University of Sheffield and University College, Swansea; it was also the third season of work for the Argolid Exploration Project, conducted from Stanford University with the help of other American institutions, and our third season in Boeotia. The same year was marked by another significant landmark: the first symposium on survey archaeology in Greece, held at the American School of Classical Studies and organized by D. W. Rupp and D. R. Keller. ${ }^{8}$

From all the above it will be clear that survey has gained a measure of acceptance among Anglo-Saxon archaeologists working in Greece. If Italy were to be included, the picture would be similar, but the stage of acceptance a more advanced one, commanding notably wide support among the Italians themselves. The second suggestion that emerges from this account is that intensive survey appears to have gained some ground in the last few years, by comparison with extensive. Whether or not it has, and more especially whether or not it should, are controversial questions. There are other issues, too, almost equally important, on which a wide range of choice (and consequently of debate) remains open to the survey archaeologist: period-selection, sampling technique, level of recording. We feel that it is

3. L. H. Sackett, V. Hankey, R. J. Howell, T. W. Jacobsen, and M. R. Popham, "Prehistoric Euboea: Contributions towards a Survey," BSA 61 (1966) 33-112.

4. S. Hood, P. Warren, and G. Cadogan, "Travels in Crete, 1962," BSA 60 (1965) 99-113; D. J. Blackman and K. Branigan, "An Archaeological Survey of the South Coast of Crete, between the Ayiofarango and Chrisostomos," BSA 70 (1975) 17-36.

5. James Wiseman, The Land of the Ancient Corinthians. StudMedArch 50 (Paul Åströms Förlag: Göteborg 1978).

6. D. Blackman, K. Branigan, et al., "An Archaeological Survey of the Lower Catchment of the Ayiofarango Valley," BSA 72 (1977) 17 84.

7. L. V. Watrous, Lasithi: a History of Settlement on a Highland Plain in Crete. Hesperia, Supplementary Volume 18 (American School of Classical Studies: Princeton, N.J. 1982).

8. D. R. Keller and D. W. Rupp, eds., Archaeological Survey in the Mediterranean. BAR, International Series 155 (Oxford 1983). unwise to be too programmatic here. The right solution in one context may lead to intolerable complication in another, and the individual survey director has the right to exercise and defend his own decision. In the long run, it will be by our results that we are judged.

\section{The Choice of Boeotia}

Most experienced fieldworkers in Greece today would agree that, of all the regions of the Greek mainland, Boeotia (FIG. 1) could claim one of the highest priorities for a field survey-provided that they did not have to carry it out themselves. This reluctance stems from a variety of causes: the absence of that kind of picturesque scenery that northern Europeans especially associate with Greece; the unattractive aspect of the towns and villages; the relative inaccessibility of the sea; and, strongest of all perhaps, the after-life of that unfavorable reputation under which Boeotia and its inhabitants labored throughout antiquity, mainly at the hands of their Athenian neighbors to the south, but with its earliest and most damaging form embodied in the disparaging words of the second-generation immigrant Hesiod, who described his adoptive home in Askra as "bad in winter, sultry in summer, good at no time" (Works and Days 640). All these critical opinions (including, no doubt, the ancient ones) have some force. It should be observed, however, that Hesiod's words, whether justified or not, have had an unwarrantably wide impact, because the climate of a site lying at over $1,500 \mathrm{ft}$ above sea level can never be taken as representative of a region, most of whose inhabited areas have always lain at less than half that altitude.

The advantages offered by Boeotia are, in any case, substantial enough to outweigh such objections. Those modern developments, whether in the form of urban sprawl, of industry, or of tourism, that have made most kinds of fieldwork generally difficult and locally impossible in other regions of central and southern Greece, have so far largely passed Boeotia by, although the recent rerouting of the main Athens-Thessaloniki highway through the ancient territory of Tanagra and the northern part of the Aonian Plain has generated a ribbondevelopment of new factories that line the road from the Attic border almost to the Thebes turning. Of the major ancient sites, only Thebes, Lebadeia, and Kopai have suffered heavily from the superposition of medieval and modern settlements. The settled agricultural population of ancient Boeotia, which was once the butt of sardonic Athenian comment, has not only survived to an unusual extent, even into the 1980 s, it also provides a near-ideal setting for the application of an archaeological technique like intensive survey, which excels in throwing light on rural rather than urban environments. 


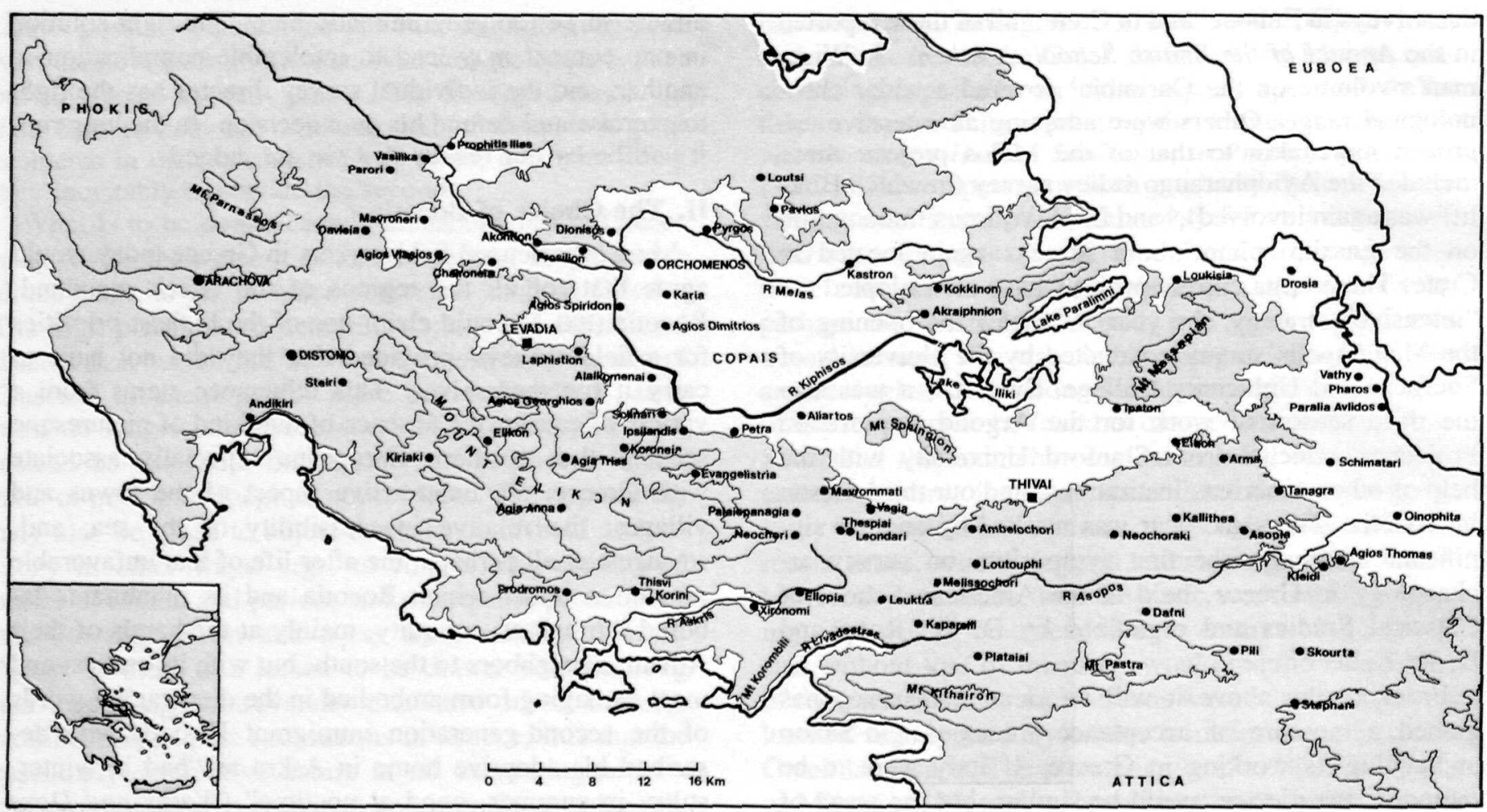

Figure 1. Location map of Boeotia.

Boeotia has the further claim that, in proportion to its historical contribution to Greek and indeed to Western civilization in general, the study of its past has been seriously neglected. In part, the shortcomings have been qualitative rather than quantitative. It could be argued that Boeotia has had something approaching its share of the intensive archaeological exploration of the past century in Greece, but it cannot be denied that the quality of the excavations, and above all of their publication, has been, with some honorable exceptions, conspicuously below the average standard. In a few cases where work on a final publication is still in hand, hope should not yet be abandoned, though the quality of the excavations themselves, particularly those of the early years, will necessarily impair that of some of the eventual publications. There is some compensation for this unhappy record in the tradition of distinguished topographical work in Boeotia. As in many parts of Greece, this can be said to have begun with the early travellers nearly two centuries ago. What is exceptional is the level and intensity with which, motivated perhaps by the failures of the excavators, it has been maintained into our own times. The decade of the 1970 s alone saw the appearance of a whole string of Boeotian topographical papers, from half a dozen different authors active in the field. ${ }^{9}$ Boeo-

9. See the periodical Teiresias: a Review and Continuing Bibliogra- tian epigraphy, too, continues to benefit from much expert work, particularly in France. ${ }^{10}$ Indeed, if this broadranging work could be matched by the publication of even one well-stratified Classical occupation-site, the cause of traditional archaeology in Boeotia could yet be redeemed. Unfortunately, even Eutresis, at present the nearest approximation to such a site, ${ }^{11}$ is vitiated by the apparent six-hundred-year interruption in its occupation, between the 12 th and the 6 th centuries B.C.

Even were this gap to be filled, however, a strong case would remain for employing less traditional techniques. Boeotia, besides being a predominantly agricultural region throughout its history, as already observed, was also for much of antiquity a federation of cities. This means that the excavation of a single urban center, which in the case of unitary city-states like Athens,

phy of Boiotian Studies (Department of Classics, McGill University: Montreal) 1- (1971-), passim.

10. Important recent publications with a primarily epigraphical content include R. Etienne and D. Knoepfler, Hyettos de Béotie. BCH, Supplément 3 (Paris 1976) and P. Roesch, Études béotiennes (de Boccard: Paris 1982).

11. Hetty Goldman, Excavations at Eutresis in Boeotia (Harvard University Press: Cambridge 1931); J. L. and E. G. Caskey, "The Earliest Settlements at Eutresis,” Hesperia 29 (1960) 126-167. 
Corinth, or Sparta would at least be likely to throw light on the central organization of government and cult, would have to be repeated many times over before any such picture could be obtained of the organization of Boeotia. Some more extended technique than excavation, embracing at least a part of the territory of several cities, is therefore more appropriate. Intensive survey seems a natural choice for the task, and, conversely, Boeotia seems to offer a good testing-ground for intensive survey. Most of the exponents and virtually all the critics of this approach maintain that, in order to be fully effective, it must depend on the presence of well-stratified excavation-sequences from nearby sites. If, as we believe, intensive survey can not only make substantial progress without recourse to excavated sources of information, but provide some of the answers to the questions that an excavation would normally be expected to settle, then a poorly-excavated region like Boeotia will provide the severest possible test for our claims. Whether or not our belief proves justified, the result will carry several lessons for the archaeology of historical societies.

The reader may feel some sympathy for our aims if he considers once more the case of neighboring Attica. Classical Athens is, from literature, epigraphy, and art, one of the best-documented societies not only of antiquity, but of all human history before the last 500 years or so of our own era. The soil of Athens and Attica has undergone scores, even hundreds of excavations in the past 200 years, a number of them executed and published in an exemplary way. Yet there are central and fundamental historical questions about ancient Athens whose answers are either unknown or hotly debated. We know that the majority of the population lived outside the city; but how did they live, and, above all, in what types of settlement? We know when and in what circumstances the governmental basis of the Athenian state was laid; but what were the exact aims of the founders, and did the result fulfil these aims? If such problems remain to be solved even in Attica, where modern circumstances make it difficult to see how they can be properly investigated, then it is justifiable to turn instead to an area like Boeotia which, though less well-known, is still a richly documented region by the standards of most of the ancient world; for here the same obstacles to inquiry do not exist.

Present-day Boeotia can, by its manifest agricultural prosperity, offer its own answer to our fundamental inquiry into the underlying causes of the historical vicissitudes that the country has undergone. When we examine these more closely, and in particular when we look at the three great periods of Boeotian preeminence-in the later Bronze Age, in the 4th century B.C., and in the 13 th-15th centuries A.C.-and their after- maths, we can with confidence accept both a negative and positive conclusion. First, the major changes in population attested by tradition for the periods between the Mycenaean and the Classical, and by history for those between the Classical and the modern, virtually exclude any "racial" explanation of the Boeotian achievement. Whatever qualities the 5th-century Athenians professed to recognize in the "Boeotian pigs," these could only be present by coincidence or by environmental conditioning in the other prominent eras of Boeotian history. By contrast, we can detect at every turn, whether in documented history or tenuous early tradition, the operation of economic and especially of agricultural factors: from the prehistoric land-reclamation of the Kopais basin to its drainage in modern times, from the growth of the Classical population to the establishment of the medieval silk industry. It is surely considerations of this kind that have exerted the most influence on the fortunes of the Boeotians. The fact that, for perhaps five-sixths of its recorded history, Boeotia has not appeared among the leading regions of Greece need not detract too much from this explanation, for the range of potentially destructive factors has always exceeded that of the constructive.

\section{Survey Methods and Techniques}

Two main considerations have led to the inclusion of this section: first, our hope that a candid account of the experiments in method that we undertook will enable other exponents of archaeological survey to benefit from our experience; second, our belief that the solution on which we finally settled is, in certain specific circumstances, the most fruitful way of proceeding. The distinctive circumstances that we have in mind are, put simply, those of a Mediterranean landscape that has a relatively well-documented history, a high density of surface artifacts but few standing monuments, and that is currently under fairly heavy farming. If one or more of these features were absent, we could well believe that quite different solutions would be appropriate.

In survey as in excavation, choices and decisions arise at many different levels and scales. In our experience, however, the two most important kinds of issue are those that arise near the two extremities of this range of magnitude: on the one hand, the initial choice of an area for intensive study within the previously-chosen region (on the assumption that the latter is too big to be covered in toto, within the limits of time and resources available); and, at the other extreme, the choice of means for investigating an individual site once its existence and location have been demonstrated (assuming, similarly, that it is too big for the whole of its area to be scrutinized at the highest level of intensity). Both of these, it will be 
seen, are in essence issues of sampling, that is, of choosing a fraction that is as far as possible representative of the whole. Whether we call these two levels "macro-" and "micro-sampling," or "strategic" and "tactical," it is these and the decisions they involve that, to us, have proved the most taxing.

In making this the starting-point of discussion, we may be criticized for having taken for granted the answer to a yet more fundamental question: why choose to conduct an intensive rather than an extensive survey in the first place? One could assert several kinds of justification: because it has proved successful in other countries, because it has not been tried on a large scale in Greece, and so on. For the present, however, we would rest our case on one argument only: intensive survey, wherever it has been tried, has brought to light a density of sites vastly higher than that recorded by extensive survey. (To make an extreme comparison, the density that we have regularly found over four years and in all types of terrain, between three and four per square kilometer, is about 50 times as high as that produced by the extensive coverage of the Minnesota Messenia Expedition. In saying this, we seek not to impugn their methods, but merely to stress the radically different aims of our own project.) The proposition, put thus simply, appears predictable to the point of banality, but it enshrines a virtually inescapable fact: the sites exist on the ground, and only intensive survey will reveal them. We do not pretend that this argument is an unanswerable one. It is open to critics to argue that the proliferation of small sites found by such surveys as ours is without any real historical significance. It is even possible for them to dispute the reality of some of our "sites." We do claim that the onus of justification now lies with these critics.

\section{The 1978 Reconnaissance}

Before initiating the intensive survey, four members of the eventual survey party undertook, in July 1978, an exploratory study of Boeotia from a central base in Thebes (J. L. Bintliff, Miss A.-M. Künzl, C. Slaughter, A. M. Snodgrass). Our primary aim was to visit the most important known sites and in so doing to form judgments as to the viability of intensive survey in that particular landscape. We, also wished to narrow down the choice of area in which to conduct the work. In the event, we visited some 75 sites, including all known prehistoric locations and most of the important ancient and medieval ones. We also, almost inevitably, came across a number of unrecorded sites. Our first question, as to the potential of Boeotia for intensive survey, was

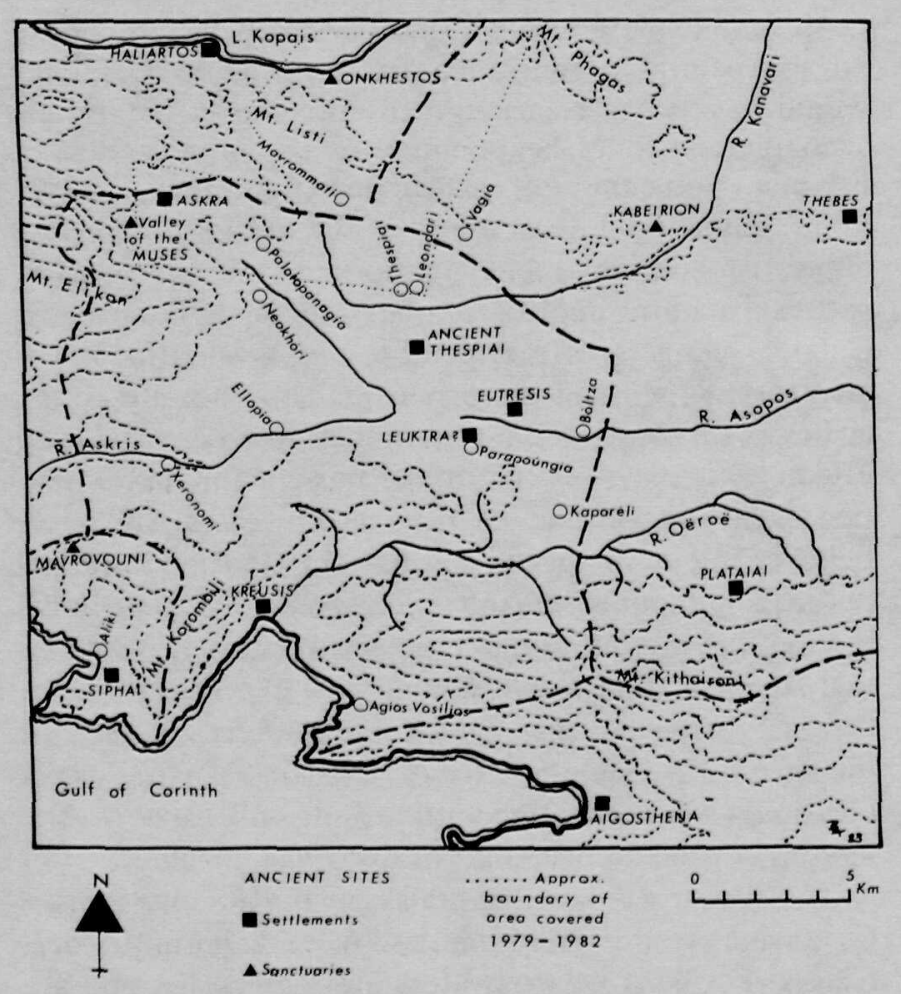

Figure 2. Location map of the survey area with ancient boundaries.

immediately given a positive answer. High density of surface finds, thanks largely to the combination of intensive modern agricultural and relatively restricted urban and industrial development, was everywhere in evidence. Equally important, the range of environment, soil, and land-use could be studied and mapped in a way that would facilitate the choice of a truly representative sample area.

\section{The 1979 Season}

In July/August 1979, we took the field for our first full season of survey. The timing and the size of the party-about 30 people in all-were to be repeated in each of the subsequent three years. The main numerical strength consisted of a group of graduate and undergraduate students from the Universities of Bradford and Cambridge, who were to make up the three field-walking parties. To these were added the subject specialists: $M$. Atherden (palynology), J. G. B. Haigh (statistics), O. Rackham (vegetation history), C. Slaughter (sociology), S. E. Warren (artifact analysis), with O. T. P. K. Dickinson supervising the pottery-recording and Bintliff and Snodgrass acting as joint directors. In addition, we had established a firm basis of cooperation with Timothy $\mathrm{E}$. 
Gregory's Ohio Boeotia Project, which was to begin work in the Thisbe area and would share its base and other resources with us.

By this time we had, of course, settled on a sample area for survey (FIG. 2). As implied in the last sentence of the preceding section, we had decided that the choice of area should be governed more by judgment than by probabilistic means, whether random or systematized. In other words, ours was to be a stratified sample, of a kind in which a diversity of land-types, as far as possible in proportion to their incidence in Boeotia as a whole, would be guaranteed. Our main reason for taking this perhaps controversial decision was the fact that the landscape of Boeotia was already the subject of a substantial pre-existing body of knowledge. The landscape had been studied not only geologically and with regard to its soiltypes, but also historically and archaeologically. To adopt a probabilistic sampling method in such circumstances seemed to us to be acting as if this information did not exist. More specifically, we wanted our sample to include not only a representative range of soils, but also parts of the territories of more than one ancient state, and to cover both terrain known to have been favored for prehistoric settlement and terrain not known to have been so favored, and so on.

Our method of proceeding was to lay over the geological and soil maps of Boeotia a grid of large 100-sqmi units, with the idea that our sample should overlap more than one of these squares and at the same time include substantial sectors of each major soil- and rocktype. We should then have an area of up to $500 \mathrm{sq} \mathrm{km}$ (or, administratively speaking, about half a dozen parishes), for which we could seek a permit to survey, and within which we could choose a smaller, equally representative sub-sample for actual intensive examination. In a region as large as Boeotia (some 2,580 sq km in all), it seemed to us that a single block of territory, rather than a scatter of smaller units, would be a more convenient form for the "outer sample," provided that one could be found to incorporate the full range of Boeotian land-types.

In the event, five major surface deposits emerged as the components of the Boeotian landscape, and the soils are closely dependent on them. Boeotia covers about 10 of our original 10 -mi squares fairly fully and partially fills three more. We first tested the variability between squares in terms of the five main surface deposits. The unpromising mountain crystalline limestone predominated in three squares to the extent of covering $60 \%$ to $80 \%$ of them, but was low or absent in four squares; pre-limestone rocks were rare everywhere; the excellent Tertiary soils were low or absent in only four squares; the important Pleistocene alluvium was low or absent in

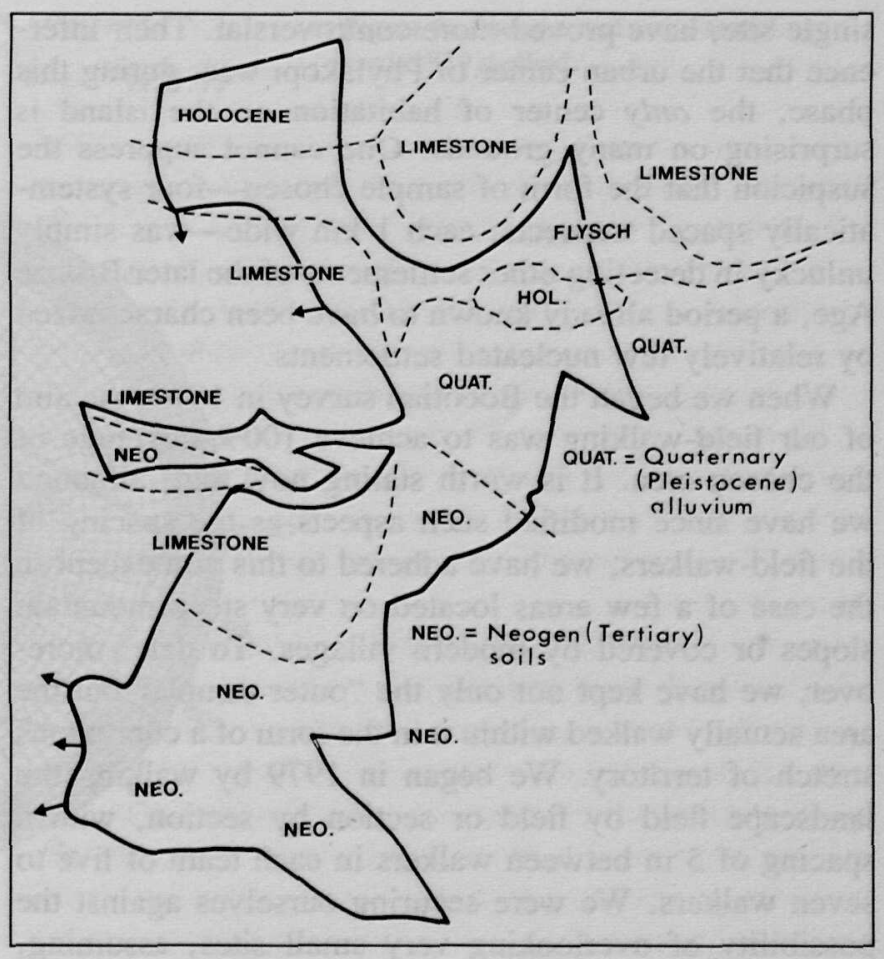

Figure 3. Geomorphology: 1979-1981 areas.

six squares. The sample area chosen (FIG. 3) was to consist of about $5 \%$ of the pre-limestone rocks, $20 \%$ of the mountain crystalline limestone, $30 \%$ of Tertiary soils, $15 \%$ of Pleistocene alluvium, and $30 \%$ of the Holocene, a figure deliberately inflated so as to include a larger area of the enigmatic and historically important Kopaic basin.

At this point we may revert for a moment to the issue of our preference for a single block of territory, rather than a scatter of quadrates or a series of systematically spaced transects. The experience of other surveys that had employed one of these latter methods suggested to us that, although they are successful in picking up a sample of the smaller, commoner, and more dispersed units of settlement, they are less so in discerning the hierarchy of settlement. By contrast, a single block of territory, if it is substantial enough, can hardly fail to represent most or all of the range of settlement types, extending from the urban center to the small isolated farmstead. Many examples could be given from British or Mesoamerican archaeology to illustrate this point, but perhaps we could take one from archaeology in Greece. The Melos Survey, which covered a $20 \%$ sample of an island of $105 \mathrm{sq} \mathrm{km}$ and discovered about 50 new sites, shows every sign of having assessed the small-site density correctly. Its findings in respect of the later Bronze Age, however, part of which was represented by not a 
single site, have proved more controversial. Their inference that the urban center of Phylakopi was, during this phase, the only center of habitation on the island is surprising on many grounds. One cannot suppress the suspicion that the form of sample chosen-four systematically spaced transects, each $1 \mathrm{~km}$ wide-was simply unlucky in detecting other settlements of the later Bronze Age, a period already known to have been characterized by relatively few nucleated settlements.

When we began the Boeotian survey in 1979, the aim of our field-walking was to achieve $100 \%$ coverage of the chosen area. It is worth stating now that, although we have since modified such aspects as the spacing of the field-walkers, we have adhered to this aim except in the case of a few areas located on very steep mountain slopes or covered by modern villages. To date, moreover, we have kept not only the "outer sample" but the area actually walked within it in the form of a continuous stretch of territory. We began in 1979 by walking the landscape field by field or section by section, with a spacing of $5 \mathrm{~m}$ between walkers in each team of five to seven walkers. We were securing ourselves against the possibility of overlooking very small sites, assuming, i.e., an effective visual range of $2.5 \mathrm{~m}$ for each walker on either side. The density of artifacts, away from the sites, was recorded but only in an impressionistic way. This was done in part because of our initial uncertainty about the level of density that would distinguish a "site," and in part because of our interest in nonsettlement "activity loci" of the kind often revealed by recent work in North American archaeology. The concept of the "non-site" has been studied, refined, and tested by excavation in, for example, the Black Mesa Project in Arizona. ${ }^{12}$ The relationship of these small localities to larger sites can also be illustrated, for instance, in the Orme Alternatives Project. ${ }^{13}$ Our transects, laid out with ranging poles and then plotted in on a general map of the area, formed a mosaic covering the whole territory, to which later reference could be made in topographic study.

As indicated earlier, however, it was the sites and their treatment that exercised us most. The sampling tactics adopted in 1979 were aimed at delimiting the size of sites and assessing their density, date, and function by means of probabilistic sampling (FIG. 4). Once a site,

12. S. Powell and A. L. Klesert, "Predicting the Presence of Structures on Small Sites," CA 21 (1980) 367-369; J. D. Nance, "Statistical Fact and Archaeological Faith: Two Models in Small-Site Sampling," JFA 8 (1981) 151-165.

13. See W. H. Doelle, "A Multiple Survey Strategy for Cultural Resource Management Studies," in M. Schiffer and G. Gumerman, eds., Conservation Archaeology (Academic Press: New York 1977) 201-209. in the form of an artifact-density "high," had been detected, an approximate center was marked by a pole. If the site area substantially exceeded $3,000 \mathrm{sq} \mathrm{m}$ ( $0.3 \mathrm{ha})$, then a series of modules, each consisting of a circle of $30 \mathrm{~m}$ radius with its central pole, was laid out so that the circumferences of the circles touched. Within each circle or set of circles, the site edge was located at points on radial lines $15^{\circ}$ apart. A computer-generated program, based on a random compass-bearing and a random proportion of the distance from site-center to site-edge, then offered up to 32 small sample units within the site. These small units were themselves in the form of circles, usually with an area of $4 \mathrm{sq} \mathrm{m}$ (1.13 $\mathrm{m}$ radius). In practice, the purely random plots proved unsatisfactory because, all too often, the central area of a site, or some other major sector of it, turned out to have no sample unit allocated to it. The computer program had, therefore, to be slanted so as to insure a reasonable apportionment between the octants of the circular site-module; while any plot that proved to lack samples from the innermost $12.5^{\circ}$ of the module was simply rejected. A second defect was that the method provided a sample amounting (according to the size and shape of site) only to between $3 \%$ and $8 \%$ of the total surface area of the site. The ground was cleared and all finds collected within each of the 4-sq-m circles: an average yield from a small (i.e., one-module) site was about 200 sherds.

These tactics of site-sampling proved very time-consuming and must partly explain the fact that in 1979 we covered, in three different areas round our base at Mavrommati, a total only of ca. $1.9 \mathrm{sq} \mathrm{km} ; 13$ sites in all were discovered. The method did, however, produce some interesting results, notably when applied by our American colleagues of the Ohio Boeotia Project in and around the city area of Thisbe. There densities of up to 46 artifacts per sq $\mathrm{m}$ occurred on bare, uncultivated terrain within the city itself, with a predictable fall-off into the surrounding landscape. This provided us with a useful yardstick for measuring the "urban density" of surface artifacts. Elsewhere, site density level was primarily determined relative to the level of the surrounding background. In practice, this usually resulted in a much lower figure of absolute artifact-density, between 0.5 and 1.5 per sq $\mathrm{m}$, for small rural sites. Nevertheless, this figure represents an average over the site area and would include higher peaks within it.

Once each site had been sampled in this way, the field team then traversed it again and carried out a simple, overall "grab" sample of any pottery that looked as though it could possibly be diagnostic. Subsequent analysis showed that the "grab" sample, besides being far swifter to operate, was much more productive in finding diagnostic material than the computer-based samples. 
CAMBRIDGE AND BRADFORD BOEOTIAN ARCHAEOLOGICAL AND GEOGRAPHICAL EXPEDITION

$\begin{array}{llll}\text { Site number Area A, site } 3 & \text { Recorded by: PLJH } & \text { DATE: } & 11.8 .79 \\ \text { Site name: Mavromati Elies } & \text { GRID Reference: }\end{array}$

SITE NAME: Mavromati Elies GRID REFERENCE

\begin{tabular}{|c|c|}
\hline \multicolumn{2}{|l|}{ SITE DIMENSIONS } \\
\hline BEARING & RADIUS \\
\hline $0^{\circ}$ & 15.8 \\
\hline $15^{\circ}$ & 13.2 \\
\hline $30^{\circ}$ & 12.1 \\
\hline $45^{\circ}$ & 12.86 \\
\hline $60^{\circ}$ & 14.0 \\
\hline $75^{\circ}$ & 17.4 \\
\hline $90^{\circ}$ & 25.9 \\
\hline $105^{\circ}$ & 24.1 \\
\hline $120^{\circ}$ & 24.0 \\
\hline $135^{\circ}$ & 25.0 \\
\hline $150^{\circ}$ & 18.0 \\
\hline $165^{\circ}$ & 15.0 \\
\hline $180^{\circ}$ & 13.0 \\
\hline $195^{\circ}$ & 11.4 \\
\hline $210^{\circ}$ & 11.0 \\
\hline $225^{\circ}$ & 11.0 \\
\hline $240^{\circ}$ & 11.8 \\
\hline $255^{\circ}$ & 13.0 \\
\hline $270^{\circ}$ & 15.0 \\
\hline $285^{\circ}$ & 15.8 \\
\hline $300^{\circ}$ & 17.8 \\
\hline $315^{\circ}$ & 20.3 \\
\hline $330^{\circ}$ & 19.7 \\
\hline $345^{\circ}$ & 17.0 \\
\hline
\end{tabular}

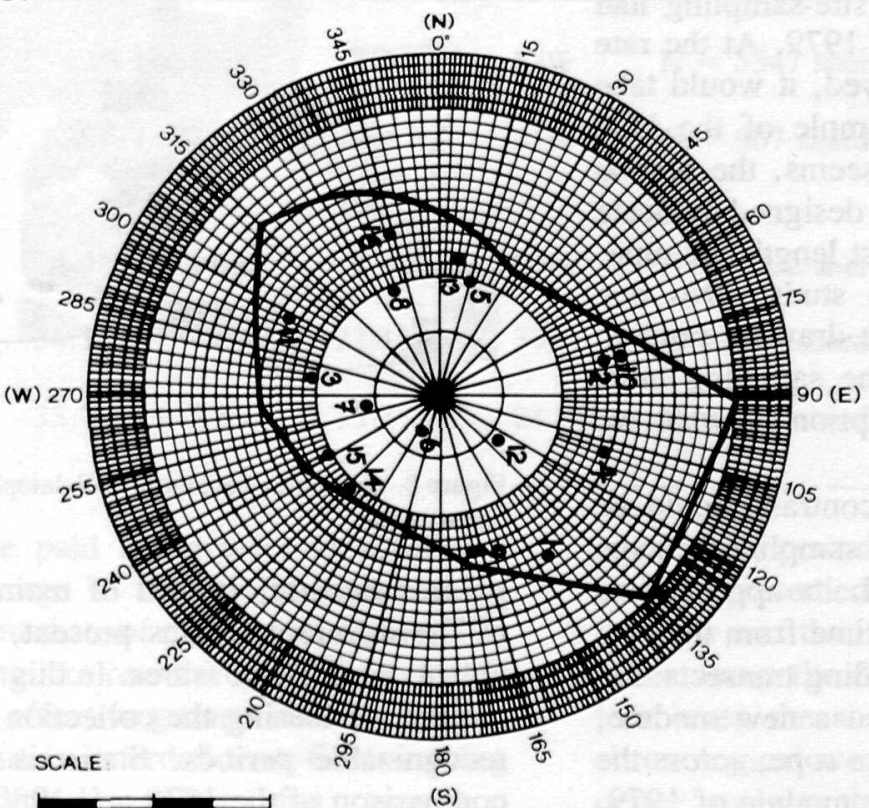

Figure 4. Specimen of a site-sampling card: 1979 method.
The latter yielded finds of which only some $12 \%$ were of help in dating the site, whereas the remaining $88 \%$ were totally undiagnostic and served only to elucidate the extent and density of the site. A much higher proportion of informative sherds was obtained from the "grab" samples, which thus saved time both in the field and in the pottery-shed.

\section{The 1980 Season}

The experiences of the first year had suggested a number of changes. Although we persevered with a standard spacing of $5 \mathrm{~m}$ between walkers, this interval was now extended in conditions of good visibility. More important, however, were the steps taken to quantify both the artifact density outside the sites and surface visibility. At the suggestion of P. L. J. Halstead, "clickers" of the type used in tallying crowds at turnstiles were introduced and distributed to the field walkers. This proved a most effective innovation, enabling the number of artifacts seen in each transect to be totalled without difficulty. Each team leader having meanwhile paced the sides of the transect as it was being walked, a figure of density per square meter was readily obtained. In areas of fairly high density, the walkers called out "sherd," "tile," and so on for each artifact that they spotted, at the same time as "clicking" them. In this way, the vicinity of a site was proclaimed by the crescendo of voices and confirmed by the subsequent tally counts. At the end of a transect, walkers were also asked to grade the visibility encountered in their particular strip of ground, on a scale to one to 10 . These figures, too, were recorded, enabling us to "filter out" the effect of surface visibility on sherd density.

As a result, it was possible at the end of the 1980 season to produce, for the first time, total density plots of pre-modern surface pottery for the landscape, which showed the expected "halo" effects round most of the sites. Where the "halo" was absent, the sites in question-mostly small, and with pottery of unusually high quality - could often be recognized as burial locations. Where there was a "halo effect" without an accompanying site, the possible explanations were either that a "non-site"-i.e., a location of activity without permanent settlement-had been detected, or that there was in fact a site there, but one whose visibility happened to be poor in the season in which it was discovered (see further below, under "An Excursus on Population Density"). These data, of course, are susceptible of considerable further analysis; there can be no immediate or simple understanding of the variations in density away from the obvious sites. We believe, however, that these density plots provide a foundation on which an entirely new application of field survey can be built; e.g., the density figures can be plotted against topographical features, such as slope, as well as against features of ge- 


\section{Cambridge/Bradford Boeotian Expedition/Bintliff and Snodgrass}

ology or land-use. Figure 5 shows a plot based on the work of 1980 and 1981 in the Thespiai and Palaiopanagia areas.

The need for a fresh approach to site-sampling had been one of the clearest lessons from 1979. At the rate of $2 \mathrm{sq} \mathrm{km}$ per year of ground surveyed, it would take us 60 years to cover even a $5 \%$ sample of the land surface of Boeotia. We were not, it seems, the first to find that a complex sampling program, designed to locate unique sample units, can consume vast lengths of time. To quote an authoritative American study, "No one wants to spend half the time on a site drawing random numbers and then trying to locate the sampling units chosen"14_a remarkably close description of what we had in fact done.

The method adopted in 1980 , by contrast, could be described as a systematically aligned sampling scheme (FIGS. 6, 7). Once a site was detected, its approximate size and shape were determined, this time from the outside, by walking a network of surrounding transects. On the site itself, there was now imposed a new module, based on a 50-m "spine" marked with a rope, across the center of the site. As with the circular module of 1979, large sites were covered by juxtaposing a series of these modules. At set intervals along the central 50-m spine, shorter "limbs" of 30-m length were set out at right angles, three on each side, each a meter in width. Sampling was carried out along each of the six "limbs," stopping at the point (often well short of $30 \mathrm{~m}$ ) where the density was judged to fall below site level. The module could thus be contracted and, within limits, expanded to match the size of the site. This system gave a steady proportion of $8 \%$ coverage of the total site area and was also appreciably quicker to operate than the 1979 method. As before, the sampling operation was followed by a simple "grab sample" coverage of the whole site.

As the season progressed, we found that, in at least one important respect, there was no improvement on the previous year. By insisting on total collection within the designated sample units, we were still burdening the pottery-shed with large quantities of material that was useless for all but numerical purposes. We therefore adopted the principle that, although the total number of finds in the sample units should continue to be counted, only a small selection of it, chosen for potential diagnostic value, would be brought back. The teams, and especially the team-leaders, were more than capable of selecting "feature" sherds (with rim, base, handle, or

14. S. Plog, F. Plog, and W. Wait, "Decision Making in Modern Surveys," in M. B. Schiffer, ed., Advances in Archaeological Method and Theory I (Academic Press: New York 1978) 383-421 (quotation from p. 407).

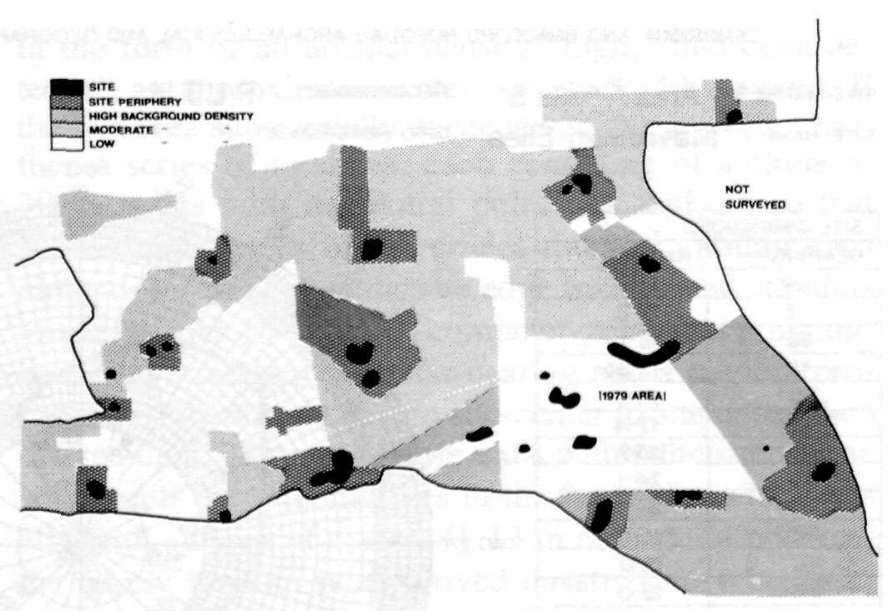

Figure 5. Specimen density plot: Palaiopanagia (left) and Thespiai (right) areas.

painted decoration) and of maintaining a cross-section of the different fabrics present, without needing to be able to identify the wares. In this way we sought to avoid the risk of biasing the collection in favor of known and recognizable periods. Statistics (TABLE 1) based on a comparison of the 1979 and 1980 pottery analyses show very consistent results. The "total collections" from the formal samples in both years make a comparably poor showing in terms of diagnostic finds. Once the change was made in 1980 to selective retention of finds from the formal samples, however, the "success rate" of informative sherds immediately rose to the same level as that of the "grab samples" in both years. This observation suggests that our teams were consistent in their practices under different collecting conditions. It was also important that the same change led to a greatly decreased load on the pottery-processing at base.

Although the average size of the sites found in 1980 was larger than in 1979, and although, as we have seen, a larger proportion of each site was sampled, the faster sampling technique, together with a slight increase in the hours spent daily in field-walking, enabled us more than to double our area surveyed (4.5 as against $1.9 \mathrm{sq}$ $\mathrm{km}$ ) and to find a larger number of sites (17 as against 13) compared with 1979.

\section{The 1981 Season}

Because analysis had shown that the field-teams were achieving a high degree of consistency in observing the density of artifacts outside the sites, and because two years' experience had shown that not even the very smallest sites were of the order of $5 \mathrm{~m}$ in diameter, before the start of the 1981 season we decided to widen the standard interval between walkers from 5 to $15 \mathrm{~m}$. There was also the important consideration that some 
Table 1. Pottery statistics.

\begin{tabular}{|c|c|c|c|c|}
\hline & $\begin{array}{c}\text { Diagnostic } \\
\text { (and possibly so) }\end{array}$ & $\begin{array}{l}\text { "Feature" } \\
\text { sherds }\end{array}$ & "Rubbish" & \\
\hline \multicolumn{5}{|l|}{1979} \\
\hline $\begin{array}{l}\text { Sample units: } \\
\text { total collection }\end{array}$ & $12 \%(+1 \%)$ & $4 \%$ & $83 \%$ & $N=5347$ sherds \\
\hline $\begin{array}{l}\text { "Grab" samples for } \\
\text { diagnostics }\end{array}$ & $38 \%(+7 \%)$ & $24 \%$ & $31 \%$ & $\mathrm{~N}=807$ sherds \\
\hline \multicolumn{5}{|l|}{1980} \\
\hline $\begin{array}{l}\text { Sample units: } \\
\text { total collection }\end{array}$ & $4.9 \%(+1 \%)$ & $2.1 \%$ & $92 \%$ & $\mathrm{~N}=4032$ sherds \\
\hline $\begin{array}{l}\text { Sample units: } \\
\text { diagnostic collection }\end{array}$ & $34.1 \%(+4.5 \%)$ & $22.1 \%$ & $39 \%$ & $N=539$ sherds \\
\hline $\begin{array}{l}\text { "Grab" samples for } \\
\text { diagnostics }\end{array}$ & $33.7 \%(+5.8 \%)$ & $35.7 \%$ & $24.8 \%$ & $N=872$ sherds \\
\hline
\end{tabular}

price had clearly to be paid if we were to achieve a significant spatial coverage of Boeotia in a reasonable time. This change meant that, of the ground recorded as covered, only something like one-third had been closely scanned, assuming that effective ground vision is limited to a 5-m strip. All densities recorded from field-walking from 1981 have therefore to be adjusted for comparison with those from 1979-1980.

Within the recognized sites, the location of the sampling units for pottery collection, whether randomized as in 1979 or systematized as in 1980 , had proved to be a time-consuming process. Yet the formal samples thus obtained had been shown (thanks to the concomitant use of "grab" samples) to be deficient in important respects:

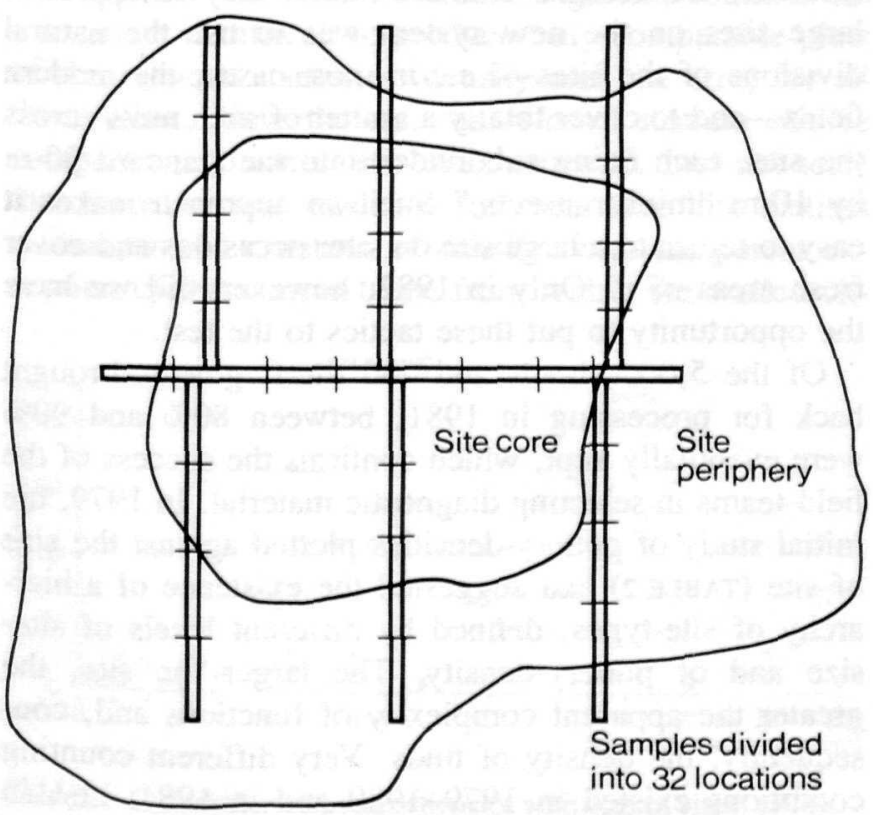

Figure 6. Schematic plan for site-sampling: 1980 method. e.g., whole periods were missed by them, but later found to be represented on the site. The function of formal samples was thus reduced to providing a basis for inferences about the density and extent of a site. Nevertheless, even the analysis of density was affected by the chronological weakness of these samples, because evidence suggests that, not surprisingly, a longer duration

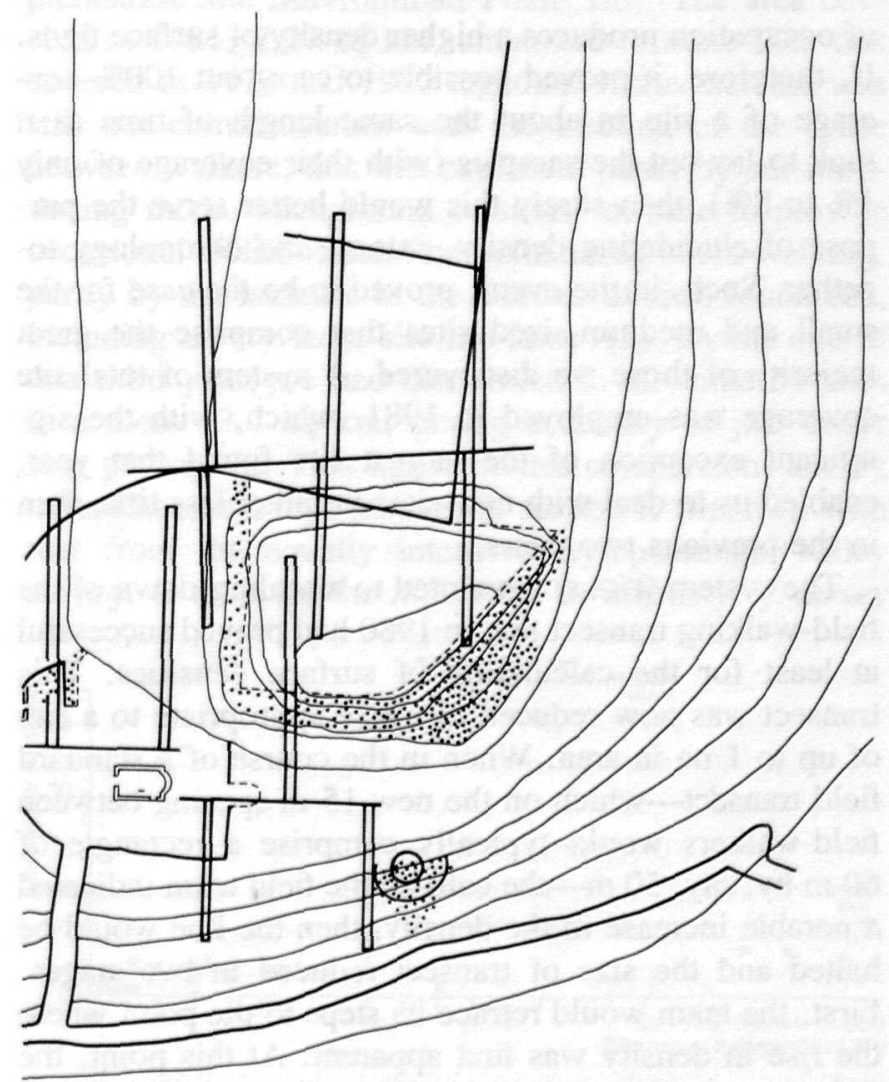

Figure 7. Schematic plan for site-sampling: 1980 method, second stage. 


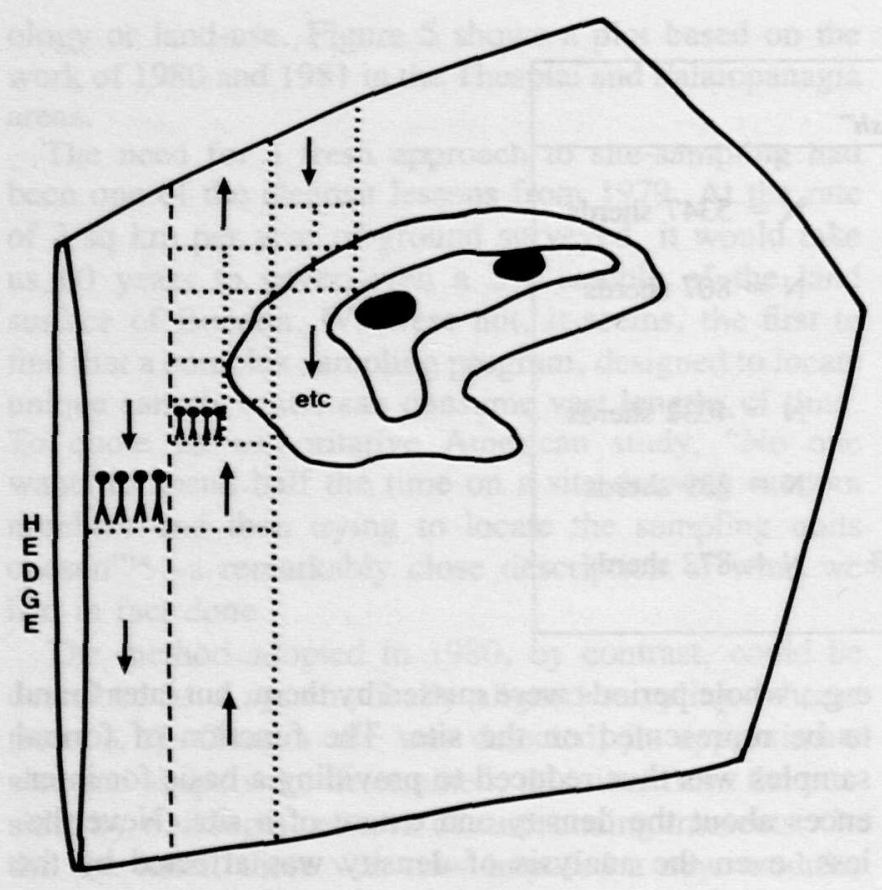

Figure 8. Schematic plan for site-sampling: 1981 method.

of occupation produces a higher density of surface finds. If, therefore, it proved possible to carry out $100 \%$ coverage of a site in about the same length of time as it took to lay out the samples (with their coverage of only $3 \%$ to $8 \%$ ), then surely this would better serve the purpose of elucidating density, extent, and chronology together. Such, in the event, proved to be the case for the small and medium-sized sites that comprise the great majority of those we discovered. A system of total site coverage was employed in 1981, which, with the significant exception of the largest site found that year, enabled us to deal with new sites in rather less time than in the previous two years.

The system (FIG. 8) amounted to a scaling-down of the field-walking transect that in 1980 had proved successful at least for the calculation of surface densities. This transect was now reduced to a size appropriate to a site of up to 1 ha in area. When in the course of a standard field transect-which on the new $15-\mathrm{m}$ spacing between field-walkers would typically comprise a rectangle of $60 \mathrm{~m}$ by, say, $50 \mathrm{~m}$ - the calls of the field team indicated a notable increase in the density, then the line would be halted and the size of transect reduced in two stages. First, the team would retrace its steps to the point where the rise in density was first apparent. At this point, the frontage would be halved to $30 \mathrm{~m}$, the spacing being in this way reduced to $7.5 \mathrm{~m}$. Walking would then resume, but in much shorter lengths and on a narrower front. Second, the moment that the density was judged to have reached "site level," the lengths of these mini-transects were immediately still further reduced to $10 \mathrm{~m}$, and the succession of these 300-sq-m units was maintained until the farther edge of the site was reached. Then course was reversed, and a second series of such units was walked, parallel to the first, and so on. The total count of artifacts for each unit was taken (again with the use of clickers) and, assuming that the density had been high enough to constitute part of a site, a selective cull of diagnostic sherds was made, usually by sifting out a somewhat larger original collection on the spot. In order to avoid duplication of counting, 10-m long ropes were thrown down along the axis of walking, between each pair of walkers. The pottery from each "mini-transect" was of course bagged separately (FIG. 9).

This rapid technique had the advantage of dividing up each site into a multiplicity of small, easily located units, for each of which a density count and (once the pottery had been processed) chronological indications were available. The limits of the site, the peaks of density within it, and the chronological changes of focus all became apparent on examination. The system worked admirably with small sites, where half-a-dozen units in two rows often sufficed to cover a site of only $0.1-0.2$ ha in extent. It also worked reasonably well with sites of up to 1 ha in area, although these could detain a team for up to a day. With the large sites of 4 ha or more, however, the technique proved impossibly time-consuming, and the need for a sampling procedure arose once again. In order to reduce the complexities of samplelocation, we decided that the easiest way to approach large sites on the new system was to use the natural divisions of the sites-i.e., in most cases, the modern fields - and to cover totally a scatter of such units across the site, each being subdivided into the standard 30-m by $10-\mathrm{m}$ "mini-transects." Such an approach makes it easy to return to a large site on later occasions and cover fresh areas of it. Only in 1982, however, did we have the opportunity to put these tactics to the test.

Of the 5,000 sherds and 500 tile-fragments brought back for processing in 1981, between $80 \%$ and $90 \%$ were eventually kept, which confirms the success of the field-teams in selecting diagnostic material. In 1979, the initial study of pottery-densities plotted against the size of site (TABLE 2) had suggested the existence of a hierarchy of site-types, defined by different levels of sitesize and of pottery-density. The larger the site, the greater the apparent complexity of functions and, consequently, the density of finds. Very different counting conditions existed in 1979-1980 and in 1981: i.e., in the first two years, the ground within each sample-unit 


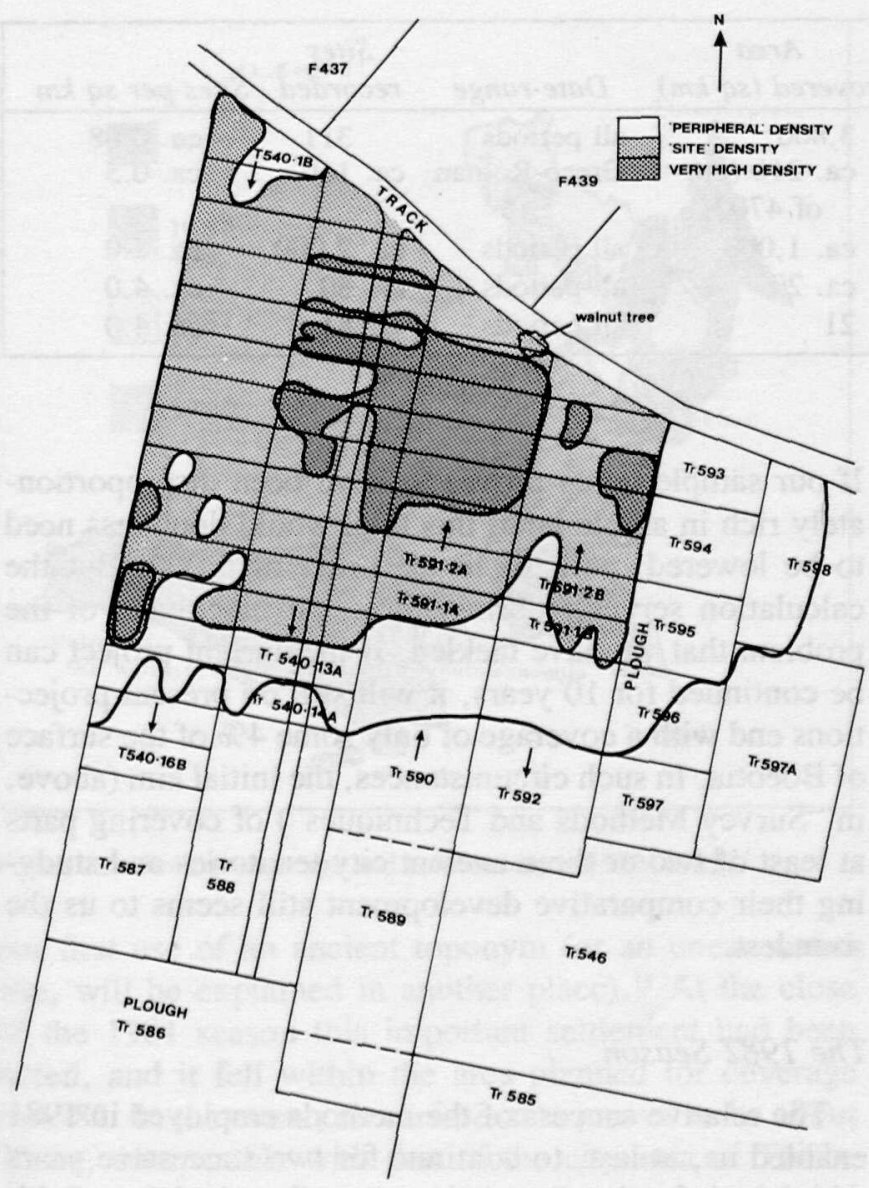

Figure 9. Specimen plan of sampling Site PP7: 1981 method.

was scoured and even the tiniest fragments counted. As a result, it is difficult to produce truly comparable plots of the relevant variables (density and site size) for all three years. Nevertheless, the relative scatters can be compared, and, on closer examination, it does not seem that there is clear evidence for separation into distinct classes on the criterion of density, with the patent exception of the sample taken from within the walled cit-

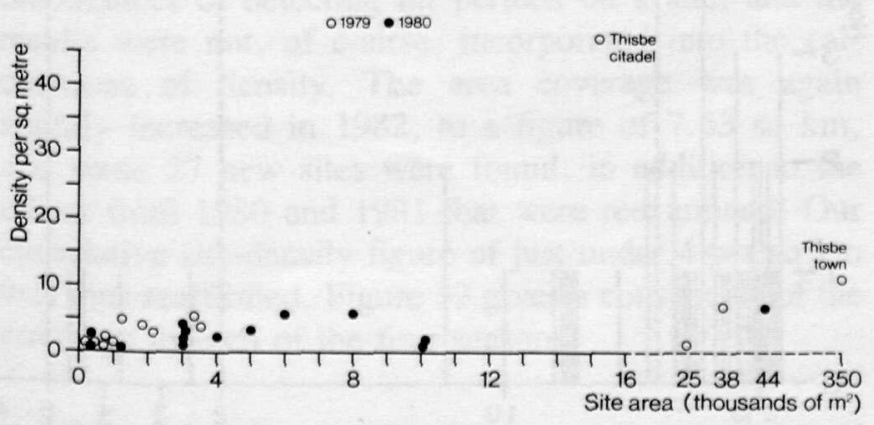

Table 2. Correlation of pottery density with size of sites, 19791980. adel of Thisbe in 1979. The rise in density, though it shows some correlation with increase in size, is shallow by comparison with the gross disparities in site-size that we encountered. Even this slight rise, moreover, may be attributed to another factor not at first taken into account: the length of the period of occupation at each site, longer site-occupation naturally producing a higher sherd-density (TABLE 3 ). The general conclusion we reach is that, for most sizes of site, the level of activity attested remains at roughly similar levels per unit of space and unit of time. Only when known regional centers were examined did multiplication of functions apparently produce density of a higher order of magnitude. The weakness of the 1979-1980 sampling methods in documenting the periods of occupation of sites (see above) precludes any more detailed inference based on site densities.

In 1981, as to a lesser extent in previous years, a satisfactory correlation was noted between the densest site-distribution and the light, lime-rich Tertiary soils and the Holocene soils round the Kopais. The Pleistocene plain clays followed a long way behind, and the mountain limestone was predictably even thinner in sites. The pre-limestone deposits, however, may have been important in some locations (as with the important prehistoric site Mavrommati Plains B3). The area covered in 1981, $7.27 \mathrm{sq} \mathrm{km}$, amounted to more than that covered in 1979 and 1980 together. If the increase was still not commensurate with the trebling of the space between walkers, this was explained partly by our introducing more "background sessions" at base to provide occasional relief from the exhausting field-walking, partly by the increase in the number of sites found (24, including a very large site in Plains A5). By the end of this third year, we had discovered in all some 54 sites in a mere $13.7 \mathrm{sq} \mathrm{km}$, giving a density of just under four per sq $\mathrm{km}$. This figure invites comparison, among other Greek surveys (above, in section I; TABLE 4), with that from the equally intensive Ayiopharango Valley survey. It must be the difference in intensity of survey

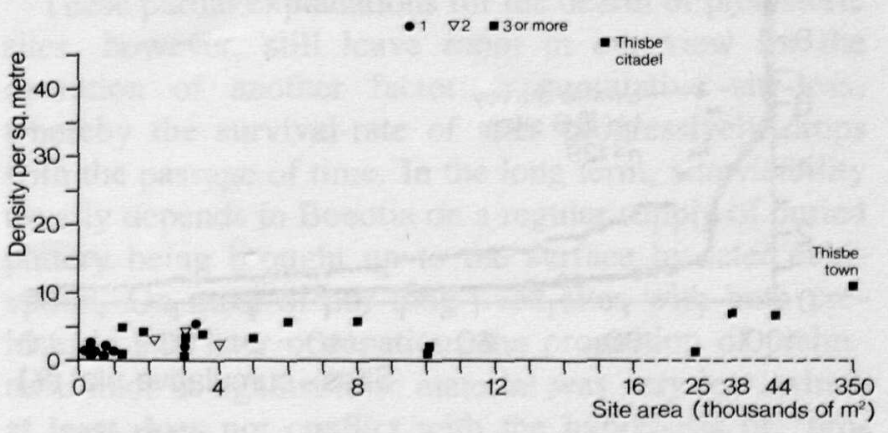

Table 3. Correlation of pottery density, size of sites, and number of periods represented, 1979-1980. 
Table 4. Comparative site density of selected surveys.

\begin{tabular}{|lclcc|}
\hline Group & \multicolumn{1}{c|}{$\begin{array}{c}\text { Area } \\
\text { covered }(\mathrm{sq} \mathrm{km})\end{array}$} & Date-range & $\begin{array}{c}\text { Sites } \\
\text { recorded }\end{array}$ & Sites per sq $\mathrm{km}$ \\
\hline Umme & $\begin{array}{l}3,800 \\
\text { ca. } 210 \text { (out }\end{array}$ & $\begin{array}{l}\text { all periods } \\
\text { of } 4700)\end{array}$ & 311 & ca. 0.08 \\
Molise & ca. 1,000 & all periods & ca. 2,000 & ca. 2.0 \\
S. Etruria & ca. 20 & all periods & ca. 80 & ca. 4.0 \\
Agiopharango & 21 & all periods & 81 & ca. 4.0 \\
Boeotia (1979-82) & 216 & & \\
\hline
\end{tabular}

that explains the gulf between such a level of density and the densities represented by other surveys on the list. We return to the comparison (above, in section I) with the results of the Minnesota Messenia Expedition. Here, in a region one-and-a-half times the size of ancient Boeotia, a total of 136 Classical to Hellenistic sites was found, although informed estimates of the then population of Messenia place it at a level of 100,000 or more. One could reasonably suggest that a more intensive coverage of Messenia would have revealed a mass of smaller sites. In support of this argument is a comparison between the Messenia Expedition's cumulative plot of site sizes for the Late Helladic IIIB period and our all-period plot of site sizes to 1981 (FIG. 10). Note how the Boeotian plot shows a very high percentage of sites so small that they barely enter the lower end of the range of site-sizes recorded for Messenia (FIG. 11).

A prediction based on our first three years' results would suggest that an intensive survey of the whole of Boeotia, even though it might take well over a century to carry out, would produce at least 10,000 surface sites, a large majority of which would have been occupied within the time-span of Classical Greek to late Roman.

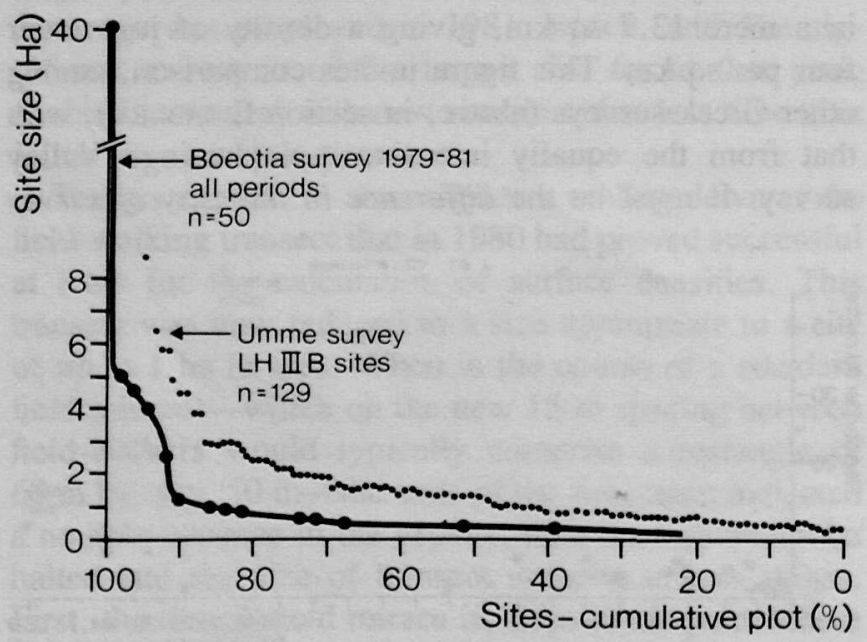

Figure 10. Cumulative plot of site sizes: University of Minnesota Messenia Expedition and Cambridge/Bradford Boeotian Expedition (to 1981).
If our sampled area proves to have been disproportionately rich in arable land, this total would doubtless need to be lowered, perhaps to the order of 5,000 . But the calculation serves to bring home the magnitude of the problem that we have tackled. If the current project can be continued for 10 years, it will still on present projections end with a coverage of only some $4 \%$ of the surface of Boeotia. In such circumstances, the initial aim (above, in "Survey Methods and Techniques") of covering parts at least of two or three ancient city territories and studying their comparative development still seems to us the soundest.

\section{The 1982 Season}

The relative success of the methods employed in 1981 enabled us, at last, to continue for two successive years without any major change in approach, whether in fieldwalking or in the treatment of sites, with the prospect of extending this approach to future seasons too. The main outstanding problem, to devise a sampling strategy for the largest sites, was presented to us in extreme form (though with a year's notice) by the site of Askra (This,

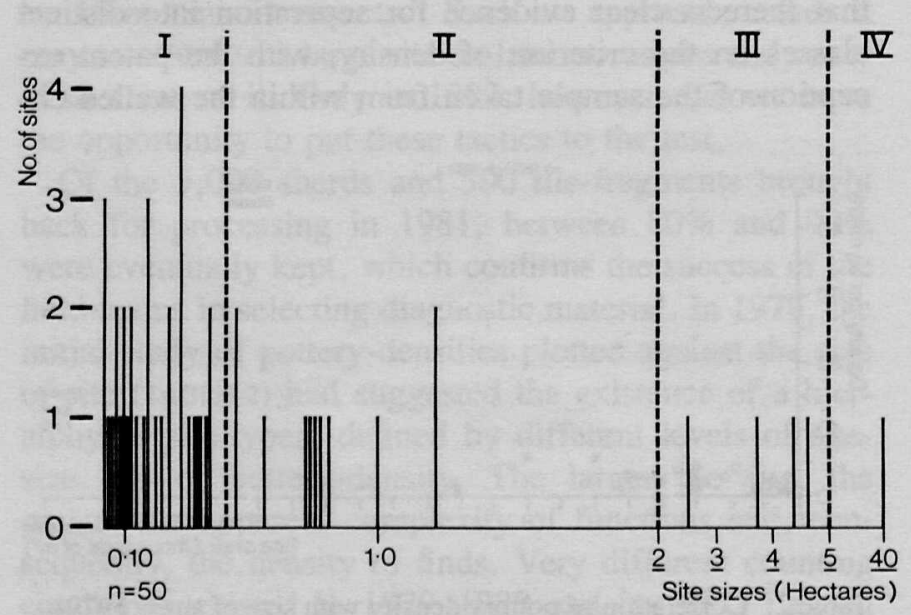

Figure 11. Range of site sizes: $1979-1981$. 


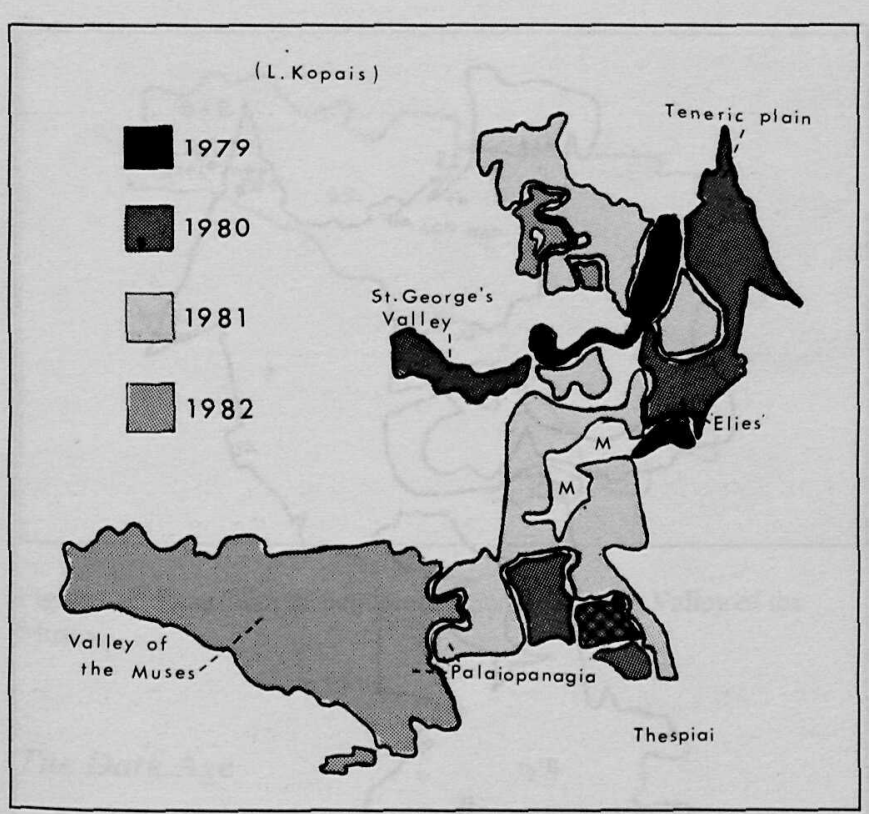

Figure 12. Annual coverage and nomenclature: 1979-1982.

our first use of an ancient toponym for an unexcavated site, will be explained in another place)..$^{15}$ At the close of the 1981 season this important settlement had been noted, and it fell within the area planned for coverage in 1982. In the event, its surface-area proved to be about 25 ha, comparable with that of the city-area of Thisbe and actually larger than the combined area of citadel and lower town at Haliartos, a neighboring polis. For a site on such a scale, the technique of sampling a scatter of individual field-units (see above, under "The 1981 Season") was employed, so far as we can judge, with success.

In 1982 we resumed the practice, not consistently employed in 1981, of carrying out a final overall "grab sample" of a site, even after it had been entirely traversed by the series of small sampling units, each with what amounted to a "grab sample" of its own (above, under "The 1981 Season"). This was done in order to maximize the chances of detecting all periods on a site, and the results were not, of course, incorporated into the calculations of density. The area coverage was again slightly increased in 1982, to a figure of $7.63 \mathrm{sq} \mathrm{km}$, and some 27 new sites were found, in addition to the others from 1980 and 1981 that were reexamined. Our cumulative site-density figure of just under 4 per sq $\mathrm{km}$ was thus reaffirmed. Figure 12 gives a conspectus of the coverage in each of the four seasons.

15. A. M. Snodgrass, "The Site of Askra," in P. Roesch and G. Argoud, eds., Actes du Colloque International du C.N.R.S.: la Béotie antique (Lyon, 16-20 mai 1983), forthcoming.

\section{Period Analysis}

\section{Prehistoric}

The adjacent Figures 13-15 first give the distribution of all prehistoric sites over the whole area so far surveyed and then a period breakdown of sites over the same area (shown this time on a larger scale and in two parts). These figures bring out the first salient feature of our results: the relatively thin and very uneven distribution of prehistoric sites of any period. The total number of prehistoric sites stands in a ratio of just under 1:5 (13 as against 69) to the number of definite Archaic to Early Hellenistic sites from the same area (despite the fact that these sites represent a period many times longer than the historic). The rich tertiary soils in the central band of our surveyed area, so much favored in later periods, are totally neglected, if one excepts an extraordinary scatter of Upper Palaeolithic flints discovered in 1981 on the plateau south of Mavrommati, near sites Thespiai E1 and E2. Correspondingly, our ratio of sitedensity to that obtained by the Messinia expedition is only about 10 times as high (or even, if one allows for the higher proportion of cultivable land in our area and calculates the number of sites per square kilometer of such land only, perhaps five times as high), as against the much bigger "multiplier" of about 50, obtained from the counts of sites of all periods (above, in "Survey Methods and Techniques"). This may in part reflect the Messenia expedition's determined search for prehistoric, especially Late Helladic, sites. Another survey on the Greek mainland that, like ours, has maintained an equal interest in all periods, the Argolid Exploration Project, has also encountered relatively few sites of certain prehistoric phases. ${ }^{16}$ Such findings may to a certain degree reflect reality. The very high site-density and correspondingly high level of population inferred for the Classical period (see next section) are unlikely to have been matched over any sustained period in prehistory, so that a thinner distribution of prehistoric sites is to be expected anyway.

These partial explanations for the dearth of prehistoric sites, however, still leave room in our view for the operation of another factor: a cumulative site-loss, whereby the survival-rate of sites progressively drops with the passage of time. In the long term, site visibility usually depends in Boeotia on a regular supply of buried pottery being brought up to the surface by later cultivation. On most of our long-lived sites with both prehistoric and later occupation, the proportion of prehistoric finds as against later material was very low, which at least does not conflict with the hypothesis of "pro-

16. C. N. Runnels, personal communication. 


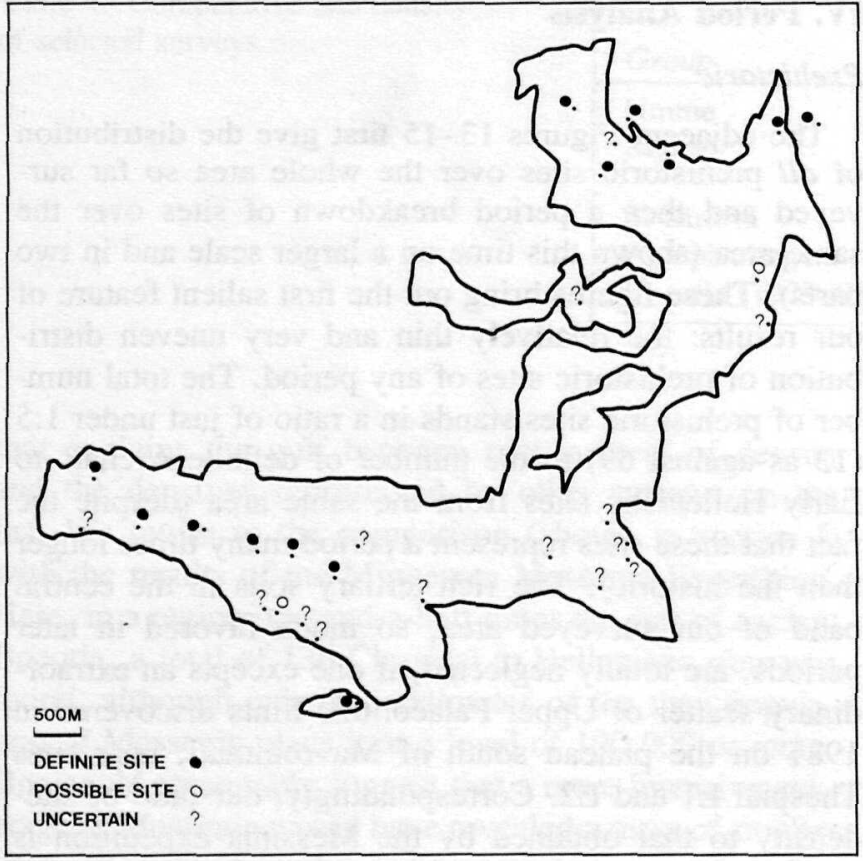

Figure 13. Distribution map: prehistoric sites.

gressive disappearance." The main exceptions were a handful of sites that, we would venture to suggest, may have formed the major local settlements of their eras. Because these were either relatively large or else continuously occupied for long periods, they produced too much material to suffer obliteration. One of these sites was Plains B3, an important settlement on a low hillock, discovered, perhaps significantly, some years ago by D. H. French. Another is the well-known site of the later sanctuary of Onchestos. The other three (all in the area of the Valley of the Muses) are all hilltop acropolis sites of the kind that features so prominently in the Messenia expedition's catalogue of Bronze Age sites. Our own view ${ }^{17}$ remains that the Messenia survey was mainly successful in locating the prehistoric sites at the upper end of the hierarchy. This view would be more convincing if backed with a wide scatter of minor sites in our own survey. Even now, however, we can point to a modest prehistoric element on some eight relatively low-lying sites (and three further possible ones), to set alongside the five "major" sites, mainly on hilltops, mentioned above.

It will be seen that our prehistoric sites are concentrated in two groups: one clusters at the northern extremity of the area surveyed, round the fringes of the Teneric

17. See A. M. Snodgrass, review of R. Hope Simpson, Mycenaean Greece, in Antiquity 56 (1982) 229-230.

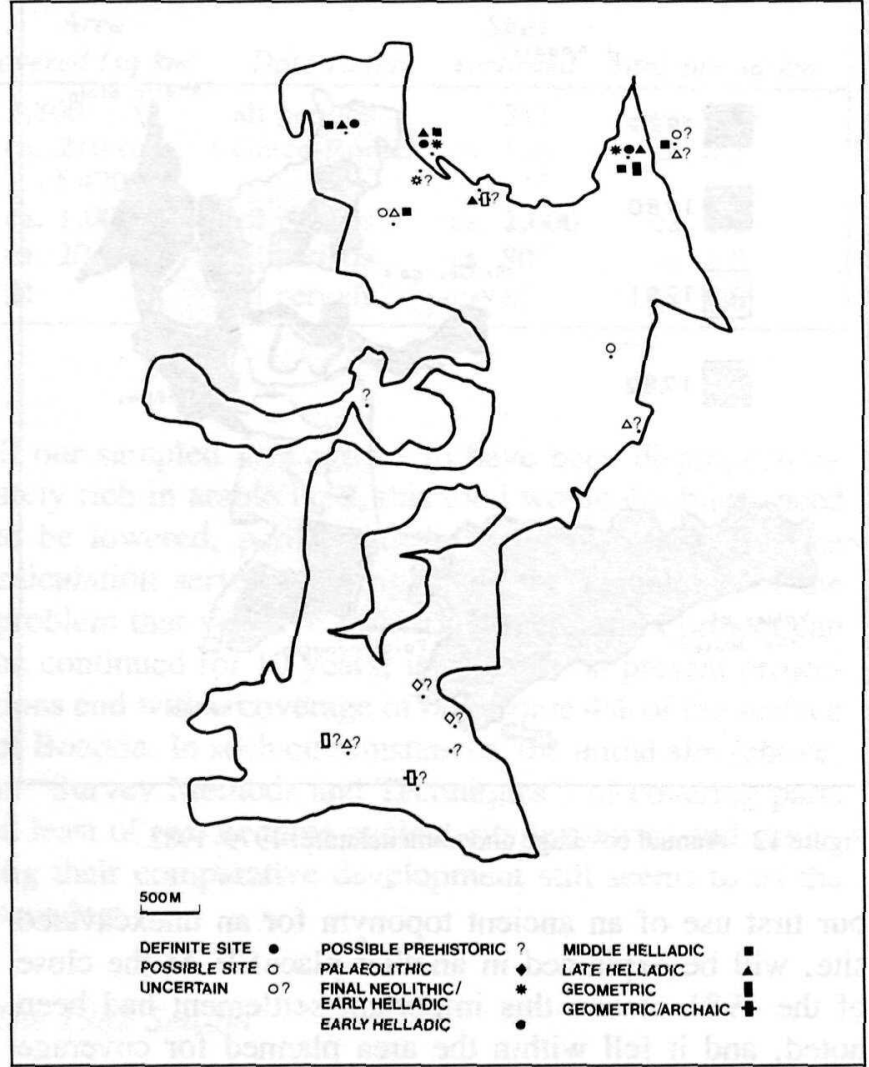

Figure 14. Distribution map: prehistoric sites in the eastern area.

Plain (running to the east) and of the Kopaic basin (lying to the NW); the other clusters, in a more natural-seeming way, down the Valley of the Muses, with the rich flysch soils, at the other extremity of our area. Both localities are in fact characterized by deposits of flysch, or of prelimestone soils of flysch-like composition. We suggest that this may have favored the preservation of the prehistoric pottery more than did the neogen light chalks that compose much of the rich but apparently empty terrain in between the two localities. For the prehistoric periods as a whole, it is safest to avoid negative arguments and conclusions based on the apparent absence of sites in certain localities. This avoidance does not, however, apply to positive inferences based on such evidence as so far exists. The northern cluster of sites, for example, does suggest a definite interest in the fringes of the Kopaic basin and of the Teneric plain (which, one may add, to this day suffers seasonal flooding in most winters, particularly in its western extremity, which lies in our area). When and if these basins were cultivable, they would offer further areas of low-lying alluvial or colluvial soils, but most of the sites had, in any case, an uphill catchment area of flysch-like soils on which to fall back. 


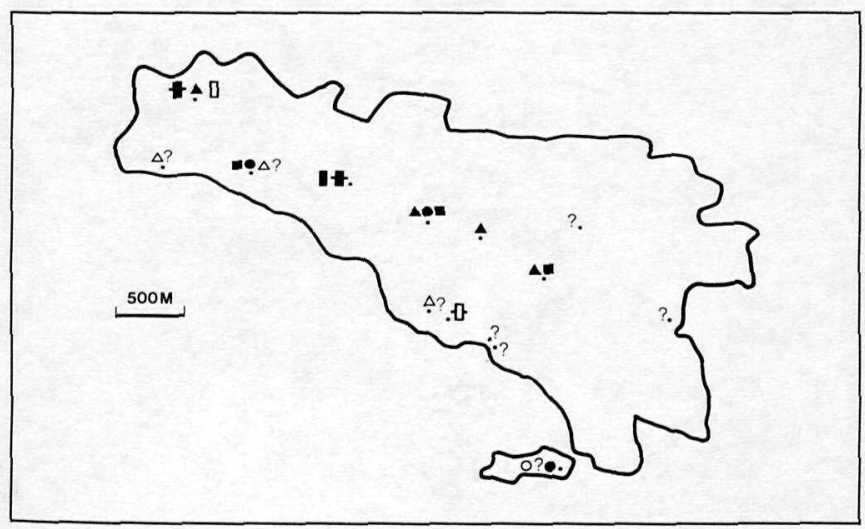

Figure 15. Distribution map: prehistoric sites in the Valley of the Muses.

\section{The Dark Age}

If the relative scarcity of prehistoric sites, at least locally, came as a surprise to us, the same could not be said in respect of the Dark Age sites. In Boeotia, as in most of the rest of Greece, this is a period for which not even excavation has enabled scholars to identify very many occupied sites. Furthermore, a high proportion of the Dark Age sites that are known in Greece, and almost all those from Boeotia, are cemetery-sites. This is not the type of site that survey can be expected to be most effective in locating, though there are exceptions from later periods (below, "Archaic to Early Hellenistic" ad fin) where we think that we have been able, from surface data alone, to establish the funerary character of a few sites. The argument used above in connection with prehistoric sites, to the effect that the chances of total or partial disappearance increase with the distance of time, begins to wear thin as we approach the threshold of the historical period. If there is still theoretical scope for the operation of another factor, the failure to recognize some coarser and perhaps less durable wares as belonging to the Dark Age, then we hope that our careful preservation of "feature" sherds, even when belonging to fabrics that cannot yet be identified or dated, will eventually bear fruit. Meanwhile, we can merely note that what Dark Age material there is-Protogeometric and Geometric at Askra, Geometric at "VM 23" and at Thisbe and Siphae (Aliki) further afield-is confined to the larger sites.

\section{Archaic to Early Hellenistic}

The mainly empirical grounds on which, in 19791981, we defined the limits of the period to which so many of our sites belong as lying in the 6th and 3rd centuries B.C. were strongly reinforced in 1982, when we had the benefit of J. W. Hayes's expertise in studying the finds of that year. He confirmed that the "Hellenistic" sherds that occurred at many of our Classical sites did indeed belong very largely in the first half of that period. In so doing, he showed that the widespread abandonment of sites, well before the time of the Roman conquest, that we had tentatively inferred, was a reality, demarcating this period at its lower end. At the upper end, it is almost equally clear that wares of a date demonstrably earlier than the 6th century B.C. occur only on a few sites, if those with a prehistoric occupation are disregarded. We are dealing, therefore, with a period of some four centuries within which finer chronological distinctions are indeed possible. Many of the sites, for example, show no sign of having been occupied as early as the 6 th, or in some cases even as early as the 5th century. Once settled, however, they continue almost without exception into the 4 th, if not into the 3rd century B.C.

The striking feature of the site-distribution of this period is its great density over the landscape (see FIGS. 16-18). The density is not, however, uniform, and the intriguing gaps that appear in it will be discussed presently. Perhaps the next most significant feature of the sites of this period is their small average size. Of the sample of 66 measurable sites that we have so far, more than two-thirds (45) appear to be of half a hectare $(5,000$ $\mathrm{sq} \mathrm{m}$ ) or less in surface area. When the debris of a settlement, even after some natural dispersal, covers an area less than ca. $70 \mathrm{~m} \mathrm{sq}$, or forms a circle of radius less than $40 \mathrm{~m}$, it becomes difficult to see it as a village or even a hamlet, at least in the Classical period. Rather, it seems, we are dealing with a mass of independent farmstead settlements and, on occasion, of their ancillary buildings: the intervals between two adjacent sites vary between $1 \mathrm{~km}$ and about $75 \mathrm{~m}$. To the important question whether or not our "sites" represent permanent structures or centers of habitation at all, we can at least give a confident answer. The invariable discovery, on all our Archaic to early Hellenistic sites, of terracotta roof-tiles can only mean that these sites contained buildings of durable construction in stone, brick, or timber. The evidence of Maude's electrical resistivity testing, where it has been applied (see below, "Geophysical Site Survey"), has reinforced this view, as does the high incidence of household pottery-shapes.

Not all our Classical sites, however, are of this small size. A group of some half-dozen, ranging between 1.0 and 2.5 ha in area, are perhaps to be ranked as small settlements. In a separate category we may tentatively place the site Plains B2, which produced not only an unusual number of worked masonry blocks, but also two sherds carrying carefully incised (though very fragmentary) inscriptions. Although this site lies less than $1 \mathrm{~km}$ 


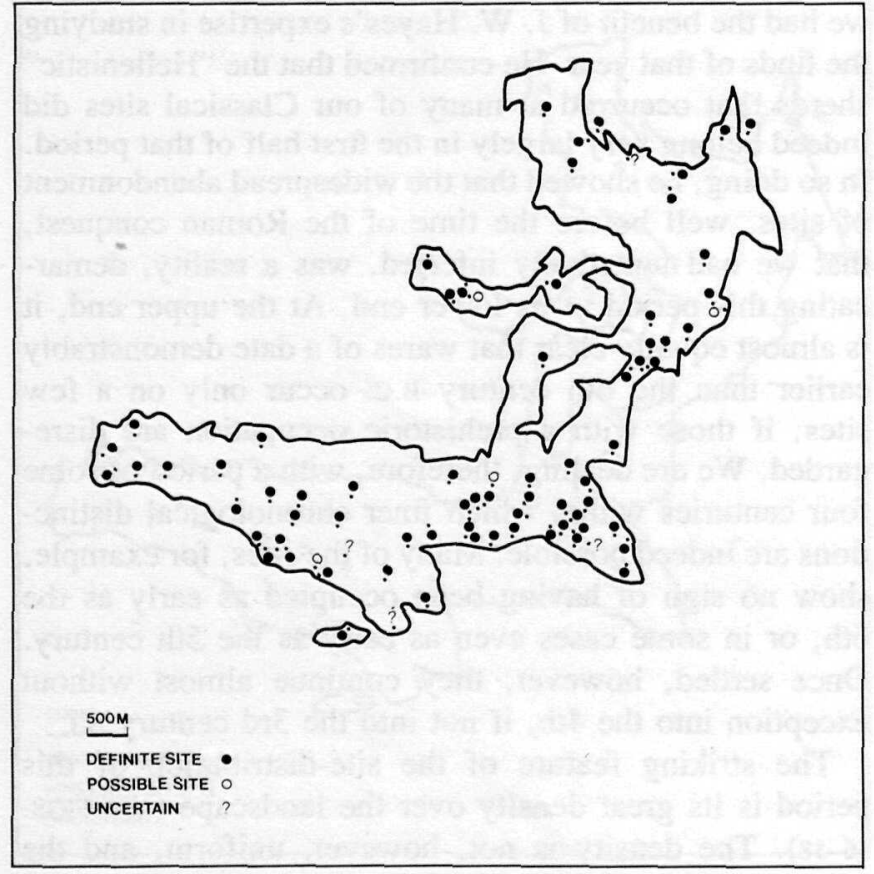

Figure 16. Distribution map: Archaic to Early Hellenistic sites.

SE from the known sanctuary site of Poseidon at Onchestos, it seems likeliest that it represents another sanctuary. We are indebted to Professor Albert Schachter for the attractive suggestion that it could be the Sanctuary of Herakles Hippodetes mentioned by Pausanias (ix.26.1). It appears to cover nearly $4 \mathrm{ha}$. In a roughly corresponding position on the other side of the Onchestos sanctuary (nearly $1 \mathrm{~km}$ wNW from it) is the even larger site Plains A5, nearly 5 ha in area. Here, again, we located many architectural fragments, including part of a substantial Doric sima and mutule, and traces of an apparent fortification-wall. In this case, there is also the evidence of a short excavation carried out within the site area by $\mathrm{Ph}$. Dakaronia in 1973, which revealed the plan of what appears to be an agora of Hellenistic date. ${ }^{18} \mathrm{We}$ should like to suggest that this represents the settlement of Onchestos (Pausanias ix.26.3 uses the word polis) as distinct from the nearby Poseidon sanctuary. Next we should mention two of our substantial prehistoric sites, Plains B3 and Valley of the Muses 4, large areas of which appear to have been reoccupied in late Classical times. In a distinct category, finally, based on their magnitude and artifact-density, belong the sites of ancient Thisbe and "Askra" (see above, under "The 1979 Season" and "The 1982 Season").

18. Ph. Dakaronia, "Seīdhi Mavrommatiou," ArchDelt 29 (1973/4) B1, 442-443.

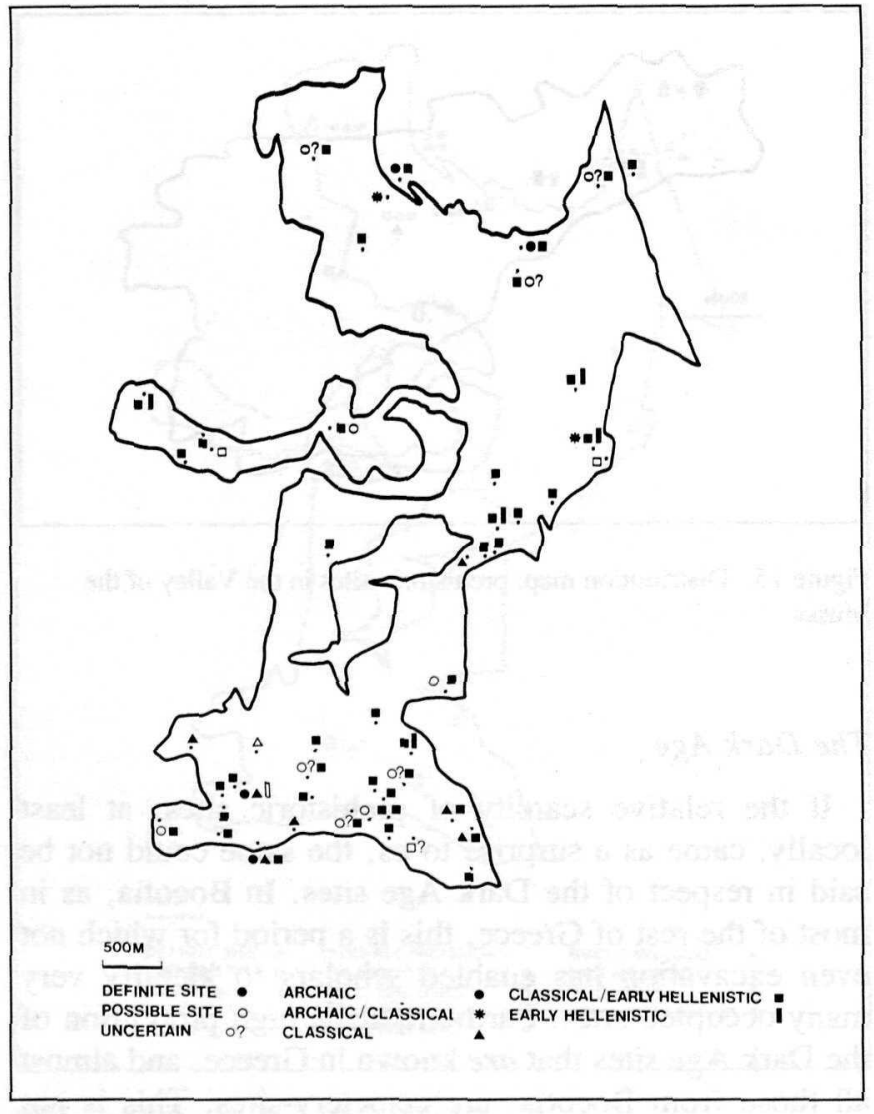

Figure 17. Distribution map: Archaic to Early Hellenistic sites in the eastern area.

Mention may also be made at this point of a few small sites that are exceptional in other ways. These are sites that produce pottery finds of exceptional quality and lack the expected quota of roof-tile fragments. Above all, the density of artifacts on these sites does not generate the habitual "halo effect." That is, the density of artifacts does not gradually fall off as one moves away from the sites proper, but instead drops abruptly to "background" level. All of these features combine to suggest that these sites-notably Thespiai E3, Palaiopanagia 11 and VM5-are rural burial-plots situated, like the "farmstead" sites, in the middle of open arable land, and covering only a very small ground-area (less than 2,000 $\mathrm{sq} \mathrm{m}$ in the cases so far identified). They would be most reasonably understood as belonging to individual family groups and, as such, the choice of location for them is of some interest.

\section{An Excursus on Population Density}

If there is one period for which some kind of preliminary demographic inferences are justified, it is this one, 


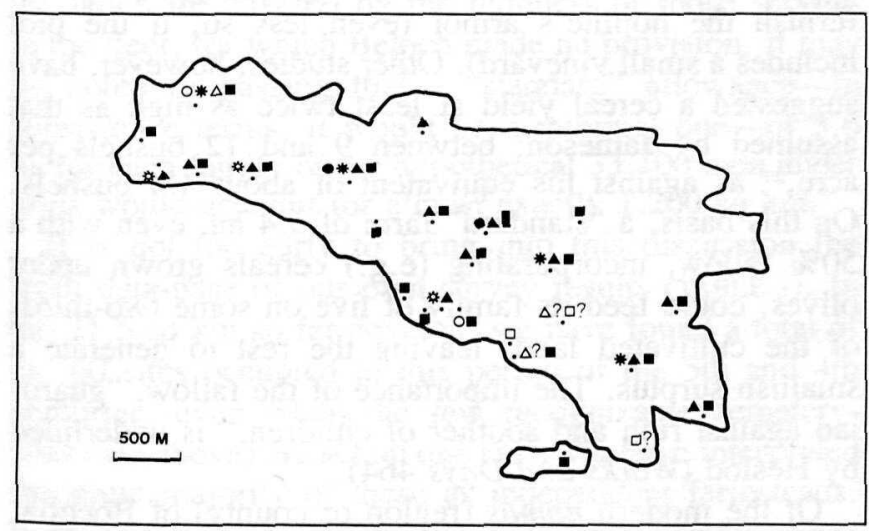

Figure 18. Distribution map: Archaic to Early Hellenistic sites in the Valley of the Muses.

with its relatively good documentation in the ancient sources and its dramatic peak in settlement-numbers revealed by the survey. The evidence from Greece as a whole makes it a safe prediction that population-levels will have risen in the course of the Archaic and Classical periods. We ourselves have found that something close to $90 \%$ of our sites, over the four years of survey, show occupation within the bracket of late Archaic to early Hellenistic. Our study of the pottery evidence to date suggests that a majority of these sites were occupied in at least part of the 4th century B.C. This was the century in which the historian Ephoros described Boeotia as a region second to none in Greece in the numbers and quality of its fighting men. ${ }^{19}$ Hence, it is gratifying that, on our evidence, this period appears to represent the zenith of dispersed settlement in the entire recorded history of the region.

The foundations of the modern study of ancient Greek population were laid by Julius Beloch's work in $1886 .{ }^{20}$ Beloch's conclusion that, in the latter part of the 5th century B.C., the total population of Boeotia was in the region of 150,000 should be set in the context of his figure for Greece as a whole at the same period, namely just over 3 million. Beloch also found that at the end of the 3rd century B.C., the time at which some of the most explicit evidence is available in the form of the epigraphic record of the muster-rolls of several Boeotian cities, the Boeotian population had not sunk far below

19. apud Diodorus Siculus xv.26.1.

20. J. Beloch, Die Bevölkerung der griechisch-römischen Welt (Teubner: Leipzig 1886) especially 161-174, 506; supplemented by his note "Die Sklavenzahl Boeotiens im fünften Jahrhundert," Hermes (1889) 479-480 and his Griechische Geschichte III, 1 (2nd edn., de Gruyter: Berlin and Leipzig 1922) 285-287, where a lower proportion of slaves to free population seems to be adopted. the figure for the 5th century. In between these two eras, he and others ${ }^{21}$ have concluded that the Boeotian total reached a peak appreciably higher than either figure. All these calculations incorporated a substantial estimated element, both for the age-groups above and below military age and, more especially, for the slaves. As such, they have attracted debate, and some later critics have argued that Beloch's figures were improbably high. Nevertheless, in 1973, C. A. Doxiadis, applying the new and quite independent techniques of ekistics, reached the conclusion that the population of Greece, in at least some periods of antiquity, had comfortably exceeded its 1971 census of 8.7 million, a figure already nearly three times as high as Beloch's corresponding one. This and other aspects of Doxiadis' results have, in their turn, been criticized by J. M. Wagstaff, in our view with some justification. ${ }^{22}$ We should not forget, however, that recent estimates, based on archaeological evidence only, for the population of Britain have yielded unexpectedly high figures, suggesting for the later Iron Age a figure of 1.5-2 million (comparable with that at the time of the Domesday Book), and for the period of the Roman occupation a higher figure of between 2 and 4 million.

Twenty years after the publication of Beloch's work, the discovery of the papyrus containing the fragmentary text of the Oxyrhynchus Historian had in any case given a new basis for discussion. ${ }^{23}$ The extant passages give clear figures for the main land army levy of the Boeotian Confederacy at about 395 B.C. Each of the 11 districts was to provide 1,000 hoplites (heavy infantry) and 100 cavalry. To this total of 12,100 men we have first to add a figure for the light-armed troops (for which no quota is given); it seems a safe inference that the numbers will have at least matched those of the hoplites. Indeed, at the battle of Delion in 424 B.C., the light-armed had considerably outnumbered the hoplites (so Thucydides iv.93.3, supported in a general way by Diodorus xii.69.3). If we content ourselves with a figure of 11,000 for light-armed, our total reaches 23,100; but to this must be added a figure for the number of seamen serving in the Boeotian fleet. P. Salmon reached the conclusion that the mean strength of the Confederacy's fleet in the later 5th century was about 50 triremes, and the evidence of several episodes in the Peloponnesian War makes this seem a fair estimate. Later, in the time of Epaminondas,

21. See, e.g., V. Ehrenberg, The Greek State (2nd edn., Methuen: London 1969) 30-32.

22. See J. M. Wagstaff, "A Note on Settlement Numbers in Ancient Greece," JHS 95 (1975) 163-168.

23. See F. Jacoby, Die Fragmente der griechischen Historiker II (Weidmann: Berlin 1926) no. 66, Fr. xi. 
there were to be twice that number of ships. ${ }^{24}$ Reckoning the company of each trireme at 200 , we have a further 10,000 men to add, giving an approximate total of 33,100 under arms in the later 5th century. If we then use a multiplier of five to reach the figure of total population (allowing, on average, an equal number of men and women, two children per family and a slave for each household), we obtain a total of 165,500 , or, if slaves are eliminated altogether, 132,400 . The resemblance between the former figure and the one that Beloch reached without the aid of the Oxyrhynchus Papyrus is, however, partly fortuitous, inasmuch as Beloch assumed a quite different figure for the slaves, the most controversial element in the sum. He estimated a slave component that was $50 \%$, not $25 \%$, of the total free population, so that his method, when applied to the Oxyrhynchus figures, would presumably have yielded a total of 198,600. What is more, the recent work of M. H. Jameson on agricultural slavery ${ }^{25}$ has suggested that Beloch's high ratio of slaves to freemen, even in a predominantly agrarian society like Classical Boeotia, is unlikely to be a gross over-estimate. There remains, however, the possibility that the Oxyrhynchus levy figures represent an "ideal" quota that could not be realized in practice, suggesting it is perhaps wisest to adopt a conservative figure of 165,500 . We do so in the belief that this is a virtual minimum for the later 5th century and that everything points to an appreciably higher total in the following century.

Recent work, notably that of Alison Cooper, ${ }^{26}$ has suggested that a common range of size for Classical landholdings was between 3.6 and 5.4 ha. The upper end of the range is most frequently represented and must lie (as perhaps the whole of this range does) within the bracket of qualification for the hoplite census, the level of property needed to place its owner in the ranks of the heavy infantry who provided their own armor. Thus, 5.4 ha might be taken as a typical hoplite holding. Jameson, in the paper referred to above, adopts a very low assumed grain-yield of $400 \mathrm{~kg}$ per ha, and an estimated annual requirement of $1000 \mathrm{~kg}$ of "wheat-equivalent" for a family of five. Careful study of the figures leads to an inevitably conflicting conclusion. Such a plot, with onethird to one-half of the land lying fallow, simply cannot meet the family's needs and provide a surplus to help

24. P. Salmon, "L'armée fédérale des Béotiens," AntCl 22 (1953) 347-360, especially 359-360.

25. M. H. Jameson, "Agriculture and Slavery in Classical Athens," CJ 73 (1977-1978) 122-145, especially 131.

26. A. B. Cooper, "The Family Farm in Greece," CJ 73 (1977-1978) $162-175$. furnish the hoplite's armor (even less so, if the plot includes a small vineyard). Other studies, however, have suggested a cereal yield at least twice as high as that assumed by Jameson: between 9 and 12 bushels per acre, ${ }^{27}$ as against his equivalent of about 4.4 bushels. On this basis, a "standard" farm of 5.4 ha, even with a $50 \%$ fallow, incorporating (e.g.) cereals grown under olives, could feed its family of five on some two-thirds of the cultivated land, leaving the rest to generate a smallish surplus. The importance of the fallow, "guardian against ruin and soother of children," is underlined by Hesiod (Works and Days 464).

Of the modern nomos (region or county) of Boeotia, some one-third was at the time of the 1961 census classified as cultivable land. Of course this figure included virtually all of the reclaimed Kopais lake-bed, some 213 $\mathrm{sq} \mathrm{km}$. If the same ratio were carried over to the smaller Boeotia of antiquity $(2,580 \mathrm{sq} \mathrm{km})$, and a deduction made for some part of the area of the lake (assuming, as our own findings suggest, that it was not entirely flooded at all times in the Classical period), then the cultivable area would not far exceed $800 \mathrm{sq} \mathrm{km}$. Nevertheless, 12,100 hoplites and cavalry, each with a "standard" 5.4 ha of farming land, would on their own account for $653 \mathrm{sq} \mathrm{km}$, leaving only a miserable residue to be distributed among the remaining majority. No allowance can be safely made for imported grain. The evidence (including the extreme paucity of imported pottery in the sites of our survey area) leads one to expect that Boeotia would be largely self-supporting, and we may recall Aristotle's mention of a Theban law (Politics 1278 a 25-6) that forbade anyone who had frequented the agora (commercial center) in the past 10 years from holding public office.

Somehow it seems the figure for agricultural production in Boeotia has to be raised still further (thus incidentally ruling out altogether the low cereal yields assumed by Jameson). If a sizeable area of present-day marginal land, such as that surrounding Rhitsona (ancient Mykalessos), was in the Classical period under plough-and at least one of our own site-locations supports this assumption - then perhaps the cultivated proportion would have been closer to one-half than to onethird of the total. This would make some $1,200 \mathrm{sq} \mathrm{km}$, rather than 800 , available and would leave a more credible area at the disposal of the poorer classes. We have not made provision for Beloch's metic population, nor yet for his element of those too poor to undertake military service of any kind, in our figure of 165,500 for Classical Boeotia. We assume that the former were liable for military service according to their wealth, and that

27. Cf. Bintliff, op. cit. (in Section 1) 634 with references. 
the latter are covered by the numbers of those serving in the fleet, for which Beloch made no provision. It may be noted in passing that a "standard" allowance-in subsistence terms, it would be a minimal one-of 3.6 ha for each family of the hypothetical 33,100 men under arms would account for almost exactly $1,200 \mathrm{sq} \mathrm{km}$.

It is not too early to bring into this discussion the fresh data-base of our own survey results (TABLE 5). In the $21.5 \mathrm{sq} \mathrm{km}$ so far covered, we have found a total of ca. 60 sites occupied in this period of the 5th and 4th centuries, even when the few recognizable cemeterysites (see above) are set on one side. We have interpreted the great majority of these as independent farmsteads. With allowance made for the frequent "hamlet"-sized settlements, with the standard household of five assumed for each of the farmstead sites, and with the overall density approaching four sites per square kilometer in this period, a general population density of around 70 people per square kilometer seems to emerge for our area, excluding Askra. By comparison, Beloch reached a mean figure of 58 people per square kilometer in his calculation for 5th-century Boeotia, a figure well short of his highest in the hierarchy of density for the regions of Greece; our own overall estimate (see above) will give a slightly higher density (about 64). After allowance has been made for the fact that the bulk of our surveyed area is prime farming-land, close to a city, and with "hamlets" as well as farms, a density of about 85 per square kilometer seems predicted. A combination of the sources suggests that our recovery of Classical sites, high though their density may seem in relative and indeed in absolute terms, may yet represent less than three-fifths of the original site- and population-density over the landscape.

Once again, it is not difficult to suggest ways in which this finding could be either explained, or alternatively explained away. On the one hand, it is highly unlikely that all of our sites were in simultaneous occupation, as was provisionally assumed in the rough calculation just made. In other words, the shortfall of sites may be very much more serious than was there suggested. Whatever the truth of that matter, it is all too likely that one of the occupational hazards of site-survey, the short- or longterm disappearance or destruction of sites, has been operating. Some sites have been found to "vanish" between the year of their discovery and the next, so that an unknown number will have been "invisible" in the year in which we covered the relevant piece of land; others again are likely to have been more permanently buried, and yet others to have been destroyed by human or natural agency. ${ }^{28}$ On the other side, it might be argued 28. Compare K. Hirth, "Problems in Data Recovery and Measurement in Settlement Archaeology," JFA 5 (1978) 125-131, for an
Table 5. Classical Boeotia: a provisional settlement hierarchy.

1. Total Boeotian armed forces $=33,100(=165,500$ total population).

2. City total (14-15 cities); if Thespiae city is 5,000 and $=1 / 11$ of Boeotian city population, $55,000=$ total Boeotian city population.

3. Satellite towns such as Askra, if 1,000 people each, perhaps 12 of these in Boeotia $=12,000$ people.

4. 165,500 minus $(55,000+12,000)=98,500$ rural population.

5. Area of Boeotia 2,580 sq km. Rural population would therefore be 38 inhabitants per sq $\mathrm{km}$ over all types of land. But if $40 \%$ of Boeotia were cultivable in antiquity, rural density per cultivated sq $\mathrm{km}$ would be 95 inhabitants.

6. Boeotia Project: $21 \mathrm{sq} \mathrm{km}$ surveyed. Should contain between 798 rural inhabitants (on 38 per sq km) and 1,796 rural inhabitants (on 95 per sq $\mathrm{km}$ ) (since $9 / 10$ ths of survey area probably cultivable in antiquity).

7. Excepting Askra, we have a possible 1,250 people in large-medium sites (11 in number), leaving 57 "farms" at ca. 5 occupants $=285$ people.

8. $1250+285=1535$. Shortfall from 1796 predicted rural total $=261=$ ca. 52 small farms.

9. Overall recovery (if all medium-large sites found) is $69: 121=57 \%$ of Classical sites.

either that the numbers given in such sources as the Oxyrhynchus Historian are idealized or "target" figures and are therefore inflated, or that the standard size of family unit that we have assumed for each small site is an underestimate. Such arguments, however, seem to us to carry distinctly less weight than those that point in the opposite direction. It seems to us that the level of site-density in the Classical period revealed by our survey to date, so far from being improbably high, is much more likely to reflect only a remnant of the original pattern.

It is in any case a secure conclusion that Boeotia in the 5th and 4th centuries B.C. was densely, perhaps very densely populated. If, as some ethnohistorical records suggest, a safe ratio of exploitation to potential carryingcapacity of a landscape is about $30 \%$, then the Classical Boeotians, for whom it is difficult to reach a figure of less than $80 \%$ exploitation, were living dangerously close to the limits of capacity of a semi-arid region. Results obtained in other parts of Greece-for example, those of the Argolid Exploration Project-suggest that

empirical investigation of the climatic and agricultural factors involved. 
these critical conditions were not confined to Boeotia.

Many episodes in Boeotian history become all too readily intelligible if set against such a background of maximal exploitation of land and population-pressure. External expansion was the invariable means for achieving what passed for economic growth in antiquity. The historical record shows that whereas the Boeotians abstained from using the external outlet of colonization, individual cities of the Confederacy, and above all Thebes, made repeated inroads upon each others' land. The pattern of the Early State Module ${ }^{29}$ in Boeotia, which is detectable in the original state boundaries of the Archaic period and matched quite closely the theoretical boundaries described by Thiessen polygons, had by late Classical times been forcibly fused into a very different pattern, at least in the areas bordering on Theban territory (as shown by the dashed lines, representing approximate Late Classical territorial boundaries, in FIG. 31). More evidence of a different kind is offered by the polygonal walling, of presumed Archaic date, visible at a number of smaller sites within a $10-\mathrm{km}$ radius to the north and east of Thebes (such as Mouriki, Syrtzi, Dritsa, and Soules, all of them visited by us in our 1978 reconnaissance). The bitter experiences of the Plataeans in Classical times are a matter of record. Such aggression on the part of Thebes may well have sprung from economic pressures; but, inevitably, they also had adverse economic results. The conquest of neighboring cities' territory and the resettlement on it of one's own surplus population not only invite reprisals, but are in themselves destructive. The damage to the sources of production, especially if these included olive-trees and vines, could well take a generation to recuperate. The loss to the peasant proprietors, all too often in antiquity, led to a long-term decline. These factors only served to make more predictable the demographic consequences in the ensuing period.

We may return for a moment to the general distribution of Classical sites in our survey area, to take up a point raised earlier: the fact that the density of sites across the landscape, though high, is not uninterrupted. The overall picture is one of a massive reinforcement and simultaneous extension of the prehistoric pattern. Much of the large gap between the two groups of prehistoric settlements (above, in "Prehistoric") is thickly filled in at this period. It will be noted, however, that at the northern extremity of our territory, in the Plains area, there is no great change, the main additions being the

29. See C. Renfrew, "Trade as Action at a Distance: Questions of Interaction and Communication," in J. A. Sabloff and C. C. LambergKarlovsky, eds., Ancient Civilization and Trade (University of New Mexico Press: Albuquerque 1975) 3-59. putative sanctuary site Plains B2 and its probable satellite B1. The reason for this was surely environmental constraint. There is every reason, from the historical evidence, to believe that the Kopaic basin was now considerably more inundated than in the later Bronze Age. We may suspect that the same was true of the Teneric plain, still seasonally flooded at its western end to this day, and characterized by very heavy, clayey soils whose cultivation would have presented problems in antiquity. To the south of this, by contrast, the upland neogen soils of the areas called by us Mavrommati Elies, St. George's Valley, Thespiai, and Palaiopanagia, are subjected to dense exploitation, while the Valley of the Muses is very much more intensely settled.

There are, nevertheless, two areas excluded from this process whereby the pattern of prehistoric settlement was both reinforced and extended. One is, understandably enough, an area of steep, barren, limestone hillslopes just to the north of Mavrommati village. The other, more mysteriously, is a band of territory, mostly covered in good neogen soils, that runs from east to west in the latitude of the southern part of Mavrommati village and stops only when it reaches the vicinity of ancient Askra to the west. This band is delineated very precisely, on its southern edge, by a track that Oliver Rackham in 1979 recognized as being of some considerable antiquity because of its sunken level. We would tentatively suggest that this track could mark a political boundary, namely that between the populous city of Thespiai to the south and, on the north side, the much smaller polis of Haliartos in one direction and the more distant Thebes in the other. This boundary must in any case be located as running somewhere near the vicinity of Mavrommati. ${ }^{30}$ The most natural place for it would be the watershed running across just south of Mavrommati, which is followed by the sunken track just mentioned, and along which the striking change in site-density occurs. We may also take account of the fact that Thespiai, besides being larger than Haliartos, also had its actual city located very much closer to the putative frontier; the distance is ca. $4 \mathrm{~km}$, as opposed to ca. 8 in Haliartos' case. What is more, access from the Haliartos side is more complicated, and, if the territory to the north belonged to Thebes, then its city was some $15 \mathrm{~km}$ away. The land on the southern side of the supposed frontier was thus almost on the outskirts of a large and prosperous city. By contrast, the land on its northern side would have represented a remote upland fringe, whether of the

30. Cf. P. Roesch, Thespies et la Confédération béotienne (de Boccard: Paris 1965) 39, Map 2, and 52 note 5, where, however, he points out that Thespian inscriptions have occurred at points well north of this line. 
territory of Haliartos or of that of Thebes, lying ca. 200 $\mathrm{m}$ higher above sea level than the city itself. Such an explanation would account for a contrast that is not justified by any major geomorphological changes. We look forward to testing it further by covering a broader strip of land to the north and $\mathrm{NW}$, to see how deeply into Haliartos' territory this "no man's land" extended.

We have summarized the main lines of our inquiry into this historic period of Boeotia's past, but serious problems remain. If, as we have tentatively assumed, our distribution of Classical sites represents only some three-fifths of their original strength, then are the missing sites to be imagined as lying in the same general districts as the concentrations we have found? This is what has been assumed in the subsequent discussion, but it is theoretically possible that they might also fill some of our apparent gaps. Another pressing question is why, if our scatter of small Classical sites represents farmsteads, they should be so densely grouped within a bare 1-2 km of the city of Thespiai. Even if they each represented a nucleated farm-plot, there would seem to be little advantage in the owner residing on them, rather than in the adjacent city. We hope that future seasons will enable us to offer some solutions.

\section{Late Hellenistic to Early Roman}

Predictable or not, the contrast between this period and the preceding one is very striking. The main features of this contrast are, first, an initial fall-off in the numbers of occupied sites and, second, a tendency for occupation to be concentrated in the larger centers (FIGS. 19-21). Of the outlying sites of the Classical and Early Hellenistic period, at least seven out of 10 seem to have become deserted at some date within the bracket 300 to 100 B.C., and fewer than half were to be reoccupied even by earlier Roman times. The standard Roman fine wares of the late Republic and early Empire such as Arretine and Eastern Sigillata are exceedingly rare finds in our area. It might be possible to explain this lack by some other cause than desertion, and the relative scarcity of imported pottery in this part of Boeotia at several periods could be cited in support of such a theory. Nevertheless, a theory it would remain. We can only point to the almost complete absence of other wares datable to these centuries and, conversely, to the presence, in a few of the larger nucleated settlements, of just such fine wares as have been mentioned. Of the half-dozen sites where we have established that occupation continues unbroken into this period, one is Askra, a substantial town-site, while another, Mavrommati Plains B3, is also many times larger than our average size of rural site. To these can be added the city of Thisbe, where our colleagues from
Ohio have proved that occupation went on into these years. Three other sites-Thespiai B1, St. George's Valley 3 and Plains A1-are also decidedly above the average size, and these, too, show evidence of having survived. The picture of a general abandonment of the single farmstead sites of the preceding period and of a concentration into town and village settlements is an internally consistent one.

It is also a picture that is strikingly consistent with our main external source for the period, the surviving writings of ancient historians and geographers. The story begins, perhaps unexpectedly early, in the pages of Isocrates, who presents a generalized but very pessimistic picture of Greece's decline. ${ }^{31}$ The writings, which range in date from the 380 s to the 330 s B.C., are patently colored by rhetorical exaggeration. In his yearning for a fictitious golden past, Isocrates complains of evils like civil conflict within the cities and warfare between them, as if these were phenomena of recent growth in Greek culture. In the specifically economic field, he bewails the effects of abolition of debts and redistribution of land, both of which were time-honored measures in Greek politics. More to the point is the insistent stress on poverty and especially on the growth of a wandering population of landless people, some but not all of whom found employment as mercenaries. None of this has particular application to Boeotia, save that Isocrates holds the Boeotians especially to blame for the upsetting of the old order. This he attributed to the Boeotians' defeat of the Spartans at Leuktra in 371 B.C. and to their subsequent liberation of the Peloponnesian states that had hitherto been, to varying degrees, under Spartan control. One cannot in fact detect in Boeotia, as early as this, any of the ill effects that so distressed Isocrates. It may rather have been its exemption from these ills that irked him, with his characteristic Athenian bias against the Boeotians. His writings at least alert us to the possibility that contemporary written evidence may still be vulnerable to distortion.

When, however, the same gloomy theme is taken up 200 years later by Polybius, there are grounds for taking the evidence more seriously. Polybius' strictures are less generalized, and one of his most eloquent passages (xx. 4-6) is expressly related to Boeotia and given a historical setting in the years $192 / 1$ B.C. He portrays an era of decline, which evidently began with the close of the Theban hegemony after 362 B.C., but reached a new pitch at the time of the generalship of Abaeocritus (ca. 245 B.C.). Loss of morale, consequent on military reverses, is the first cause that he instances for the debacle;

31. See A. Fuks, "Isocrates and the Social-Economic Situation in Greece," Ancient Society 3 (1972) 17-44. 


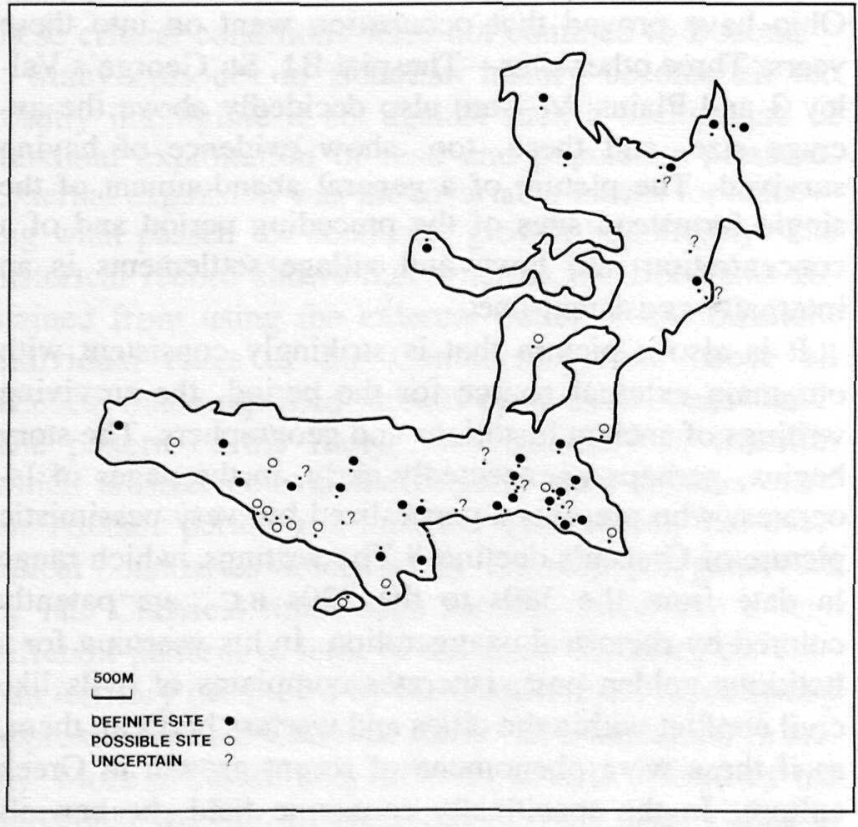

Figure 19. Distribution map: Late Hellenistic/Early Roman sites.

later political errors, he argues, compounded it. The ultimate symptoms, in the years around 200 B.C., include the breakdown of justice, the use of public funds for doles to the poor, and the frivolous squandering of private capital. ${ }^{32}$ Polybius does not here spell out the practical economic implications. For these, we have to turn to xxxvi.17.5, a passage that applies to Greece as a whole, but which isolates one particular adverse factor.

In our times the whole of Greece has suffered a shortage of children and hence a general decrease of population, and in consequence some cities have become deserted and agricultural production has declined, although neither wars nor epidemics were taking place continuously.

This analysis probably reflects the state of affairs after 146 B.C., when Polybius was engaged on the later part of his history. The account is the more striking for the contrast that it makes with a passage written earlier (ii. 62.4) in which the exceptional prosperity of the Peloponnese is casually mentioned, and which can be related to the period between 181 and 146 B.C. ${ }^{33}$ Polybius' view of the ills of Greece thus seems more discriminating than Isocrates' had been, even beyond the fact that he singles out Boeotia as suffering from them in their extremest form.

32. See F. W. Walbank, A Historical Commentary on Polybius III (Clarendon Press: Oxford 1979) 66-74.

33. Walbank, ibid. 680 and vol. I (Oxford 1957) 267-268.

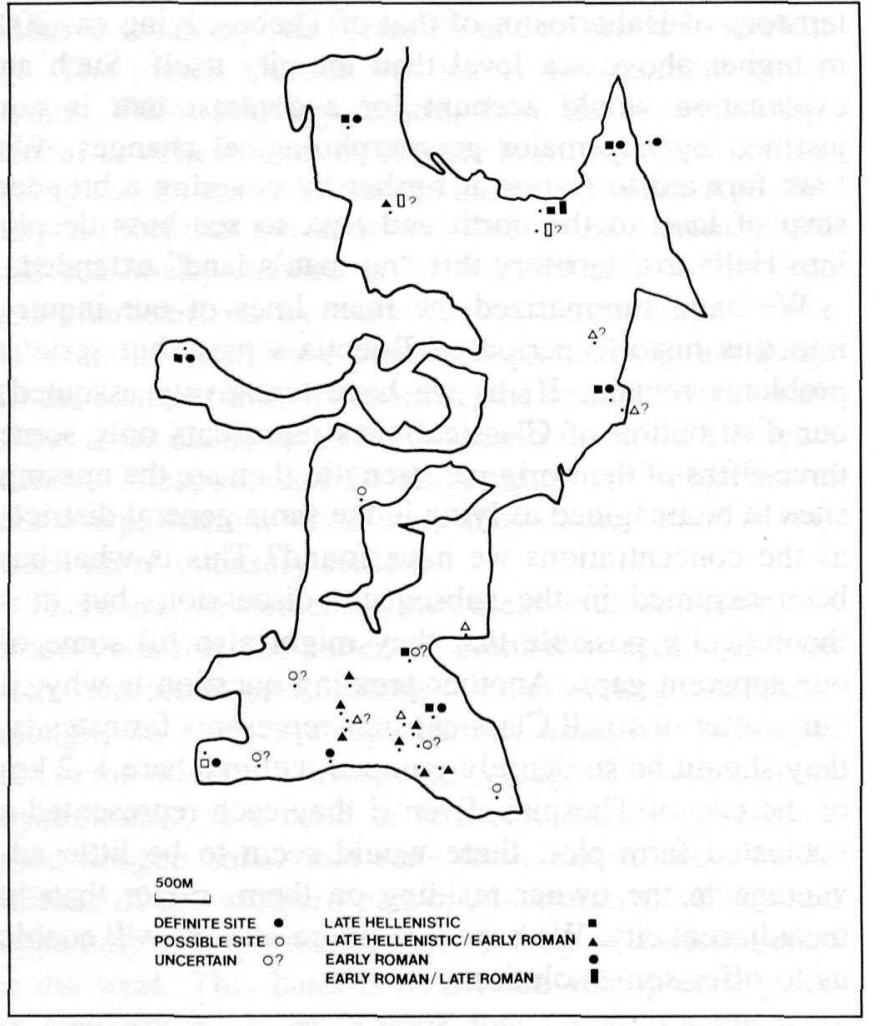

Figure 20. Distribution map: Late Hellenistic/Early Roman sites in the eastern area.

The ultimate confirmation that Boeotia had undergone a genuine and severe decline, at least in certain respects, during the Hellenistic age is provided by Strabo's $G e$ ography, probably published in the last decade B.C. but using somewhat earlier sources. ${ }^{34}$ The evidence must once again be handled with a degree of caution, because it is doubtful whether Strabo's account is based on extensive first-hand experience, and he can certainly be convicted of exaggeration in places. His derogatory statements about contemporary Boeotia are, in any case, largely confined to the condition of its cities. Strabo dismisses several Classical polis sites as mere villages, says a few are entirely deserted, and credits only Tanagra and Thespiai with even moderate prosperity. Unlike Polybius, he does not specifically mention agricultural recession, but it is hard to believe that the shrunken towns of his day were compatible with a flourishing countryside. In any case, there is some earlier epigraphic evidence that sounds a note of alarm. From the early 2nd century on, inscriptions tell of measures taken to combat grain shortages. The annual lists of those reach-

34. See P. W. Wallace, Strabo's Description of Boeotia (Carl Winter: Heidelberg 1979) especially 3, 173-178. 


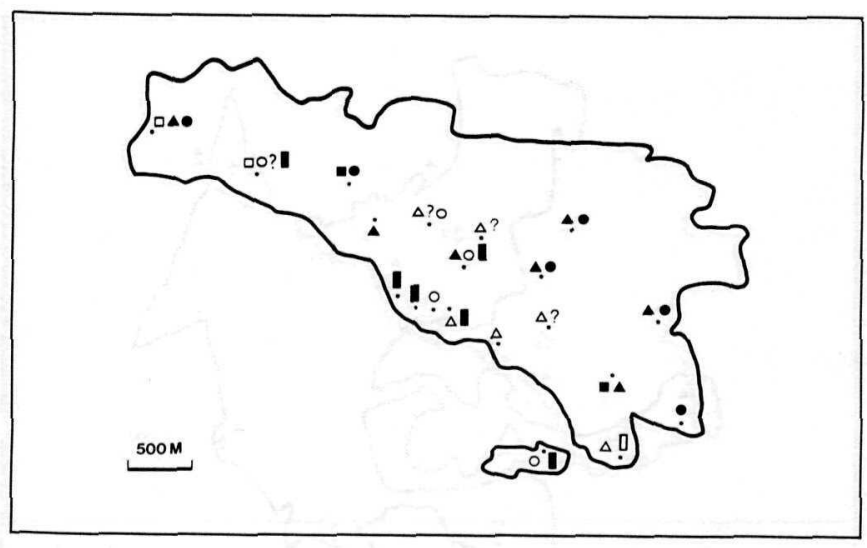

Figure 21. Distribution map: Late Hellenistic/Early Roman sites in the Valley of the Muses.

ing military age in the little city of Hyettos are also instructive. ${ }^{35}$ Between 245 B.C. and 165 B.C., the average numbers reflect a total male population of about 570 and a total levy of those of military age of less than 300. By contrast, in the early 4th century, under the arrangements described by the Oxyrhynchus Historian, Orchomenos and Hyettos together (following the only plausible emendation of the text) had been responsible for fielding a land force of 2,200 men. It is not known what proportion of this figure was provided by Hyettos, though undoubtedly it will have been less than half. Still, the figures are enough to suggest a substantial loss of population on the part of Hyettos over the course of two centuries. The evidence for Orchomenos itself in the later period, and for other cities including (significantly for our survey area) Thespiai, is enough to confirm the strong downward trend.

Just as Strabo's account supports our belief that a wave of desolation had spread over Boeotia in the Hellenistic period, so its continuance into the Roman Imperial period is confirmed by Pausanias, whose Description of Greece was written over a stretch of two decades between the 150s and the 170s of the Christian era. It is not that Pausanias positively emphasizes the decline and depopulation of the countryside; what is noteworthy is rather the way in which he apparently takes for granted the fact that settlements of the Classical period had become, in his day, merely "ruins." In the case of Pausanias, it is the second-order towns that particularly receive this description. The catalogue of "ruins" begins almost from the moment that he enters Boeotian territory and

35. See P. Roesch, “Notes d'épigraphie béotienne," RevPhil 39 (1965) 256-261; R. Etienne and D. Knoepfler, op. cit. (in note 10) 201-210; 209, note 705 for further testimonia on corn shortage; 203, note 688 for Thespiai, but with a different explanation of the drop in enrollment after 171 B.C. includes Hysiai, Erythrai, Skolos, Potniai, Glisas, Harma, Mykalessos, the settlement of Onchestos, Askra, and Aspledon. Other small towns are described as "villages" in a way reminiscent of Strabo, but unlike him Pausanias seems to find substantial communities established in most of the major Boeotian cities. The crop of civic inscriptions of Roman Imperial date from Boeotia is rich enough to suggest a measure of urban recovery by Pausanias' day.

For the mainly rural area so far covered by our survey, however, the picture suggested by the archaeological evidence is one of almost undiluted recession. The two identifiable settlements in our area that are mentioned by Pausanias, Askra and the "city" adjoining the Onchestos sanctuary (above, in "Archaic to Early Hellenistic"), having both enjoyed continued occupation in Hellenistic times, now show every sign of having been deserted as Pausanias says. This last fact is of course helpful in establishing their identification, which had been debated in the case of Askra and not attempted in the case of the Onchestos settlement. Whether or not these two sites are correctly named, they were unquestionably major second-order centers, with nuclei covering some 25-30 and 5-10 ha, respectively. When such a range of settlements, from farmstead to market town, falls into dereliction, it is scarcely conceivable that agriculture can have flourished without impairment. Nor are there signs of major recovery for a long time after Pausanias' travels.

All of this makes it the more astonishing that the revival, when it did eventually come, was so complete. There is nothing in the scanty documentary sources for the later Roman Empire to prepare us for the surge of repopulation of the Boeotian countryside that seems to have taken place in the years after 300 A.C.. Only in the experience of other intensive survey projects in Greece do we find some kind of parallel phenomenon. It is comforting to find that the Argolid Exploration Project (to name one conspicuous example) encountered a comparably marked fall-off in settlements, at least locally, in the later Hellenistic and earlier Roman periods. ${ }^{36}$ This was followed, in their case, by a positive shift in the settlement pattern in Late Roman times and a much later reversal of this shift in the Middle Byzantine period, whereas our experience in Boeotia, as will emerge in the following section, was somewhat different.

\section{Late Roman}

This period, extending over the 4 th to the 6 th centuries A.C., produces a distribution of sites that immediately

36. C. N. Runnels, personal communication. 


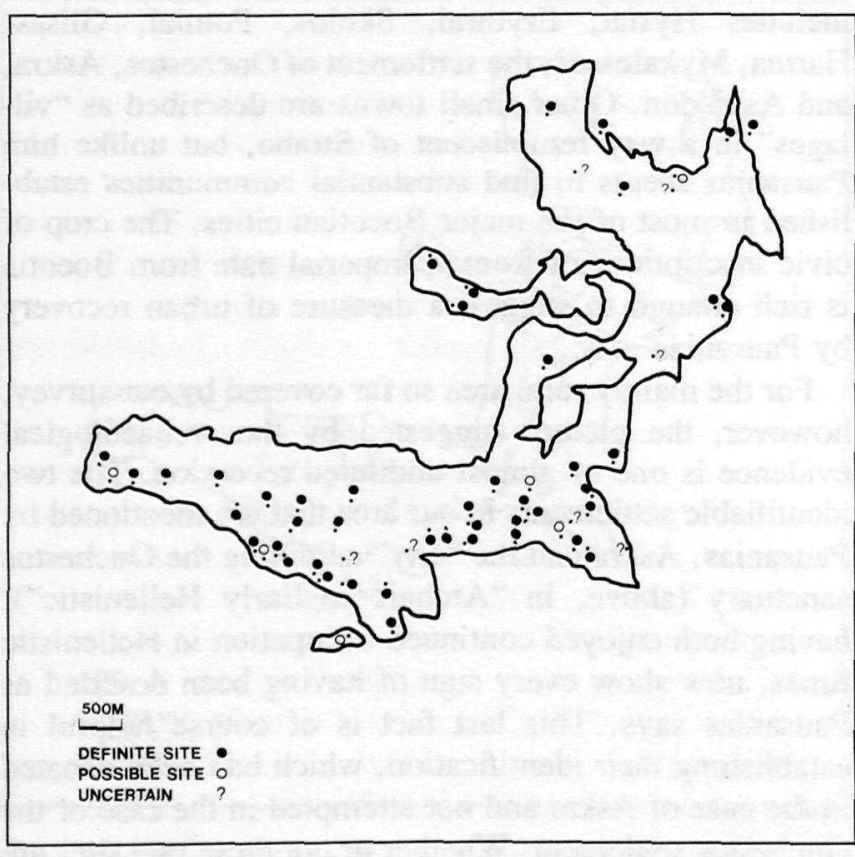

Figure 22. Distribution map: Late Roman sites.

recalls that of the Classical Greek period, in general outline and indeed in detail (FIGS. 22-24). The fact is that over 40 of our Classical sites-something like twothirds-show evidence of having been reoccupied in this period, nearly all of them after an intervening period of desertion. A handful of fresh sites, in addition, are now settled for the first time, to give a total distribution nearly as dense as in Classical Greek times.

It was U. Kahrstedt's conclusion, in his study of economic conditions in Greece under the Roman Empire ${ }^{37}$ that by this time large areas of Boeotia had been turned over to Imperial and other large-scale estates, with some of the lesser towns being replaced by such estates. Two features of our Late Roman site-pattern arguably provide limited support for this picture. First, one or two Classical sites offer evidence that the occupied area of the now resettled site was more extensive than it had been before. Second, of the 20-odd Classical sites that are not now reoccupied, almost all are very small, even by the standards of the Classical pattern. The overall pattern of land-holdings would thus, to some extent, appear to have been less fragmented than in the earlier period. This trend is, however, not very pronounced, and by far the most striking feature of the period must remain the density of rural settlement, together with its obvious dependence on the earlier, Clas-

37. U. Kahrstedt, Das wirtschaftliche Gesicht Griechenlands in der Kaiserzeit: Kleinstadt, Villa und Domäne (Franke: Bern 1954) 86$87,93,100$.

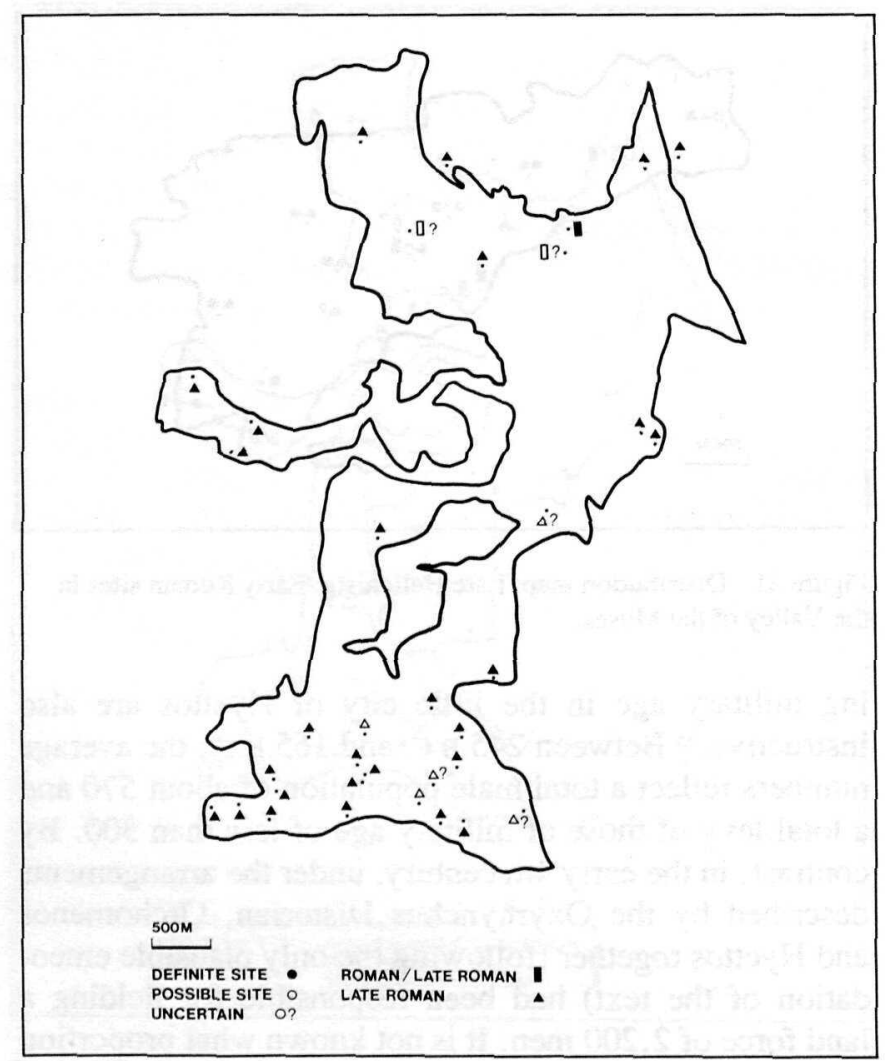

Figure 23. Distribution map: Late Roman sites in the eastern area.

sical pattern of locations. The paucity of contemporary documentation compels students of this period, for most areas of the ancient Mediterranean, to fall back on archaeological evidence; and it is archaeology that has brought the realization that, in parts of the Eastern Empire, though not in the west, these centuries must have seen a remarkable resurgence of prosperity. Our colleague, T. E. Gregory of the Ohio Boeotia project, has argued $^{38}$ that the polis tradition of the Eastern Empire (contrary to the traditional view) proved an unexpected source of strength in an era of general decline. Certainly the dense resettlement of the northern limits of the territory of Thespiai, which our map clearly demonstrates, suggests a recovery on the part of that city and a marked revival of its dependent village, Askra. Conversely, one aberrant feature of the site-distribution, the failure to resettle more than one of the eight small Classical sites in our Elies area, may point to the weakness or even the virtual absence of a central authority in Haliartos, a city which (as Kahrstedt points out) ${ }^{39}$ for practical purposes

38. T. E. Gregory, "The Fortified Cities of Byzantine Greece," Archaeology 35 (1982) 14-21.

39. Op. cit. (in note 37) 105. 


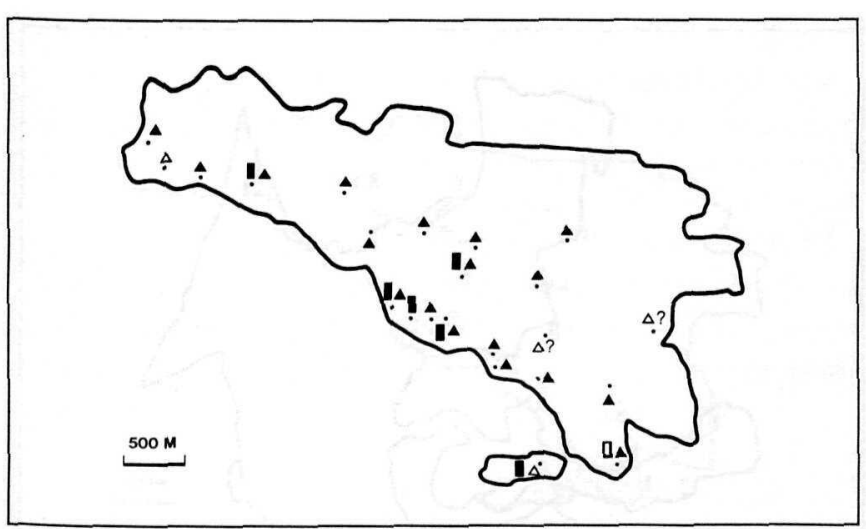

Figure 24. Distribution map: Late Roman sites in the Valley of the Muses.

no longer existed at this time. The presumed sanctuary site, Plains B2, which must also have belonged to Haliartos, is conspicuous as one of the very few large Classical sites not now reoccupied, while the evidence for a revival of activity at the Onchestos sanctuary is relatively weak.

\section{Byzantine and Turkish}

To lump together some 12 centuries of relatively recent history into a single period may seem crude, but even to produce a site-survey map for these centuries, with period sub-divisions (FIGS. 25-30), is something that few if any of our predecessors have been able to achieve. Such is the level of background knowledge in this field. The greater precision shown in Figure 27, which covers an area surveyed entirely in 1982, reflects our steadily increasing knowledge of the subdivisions of pottery-style as compared with previous seasons. We hope that, with our pottery experts having access to the material from the 1979-1981 seasons in the Thebes Museum and with the progress of the work on contemporary documentary sources, we shall be able to extend and improve upon this level of expertise.

Already parts of the general outline are becoming clearer for our area. The Early Byzantine period, from the 7th to the 9th centuries, is seen as one of impoverishment and desolation rivalling that of the earlier phases of decline. Only the site of Askra in the Valley of the Muses apparently survives through this period, though beyond our boundaries there are some towns-notably Thebes itself- that are known to have preserved some of their vitality. The Middle Byzantine period shows a measure of recovery in rural settlement; this is the time of the building of the Skripou church at Orchomenos and of the foundation through a Theban initiative of the church and monastery of Osios Loukas to the west, two independent signs of returning stability and recovering prosperity in Boeotia. The Late Byzantine period after 1204 A.C. shows, at least in our better-documented 1982 area, a relatively impressive density of settlement. Here we move into the era of the successive occupations by the Frankish powers, of which the most durable physical trace is provided by the surviving Frankish towers that dot the landscape of Boeotia. The most significant historical legacy for our region was the settlement of the Albanian immigrants, mainly under Florentine auspices. It is significant that the ruined tower in the Valley of the Muses forms the nucleus of another of our large sites, VM 4, which from the 13th to the 17 th centuries seems to have taken over the role of the principal settlement of the valley from VM 21 (which itself can be seen as the post-Classical successor of Askra). Our findings suggest that the Albanian settlement, traditionally within garrison-type villages, may have been firmly based on the earlier pattern of settlements. An example is our own base-village of Mavrommati, on the NW edge of which we found a Late Roman and Byzantine site, but which is recorded by its present-day inhabitants as having been chosen as the site for an Albanian stratochori (garrisonvillage), by transplantation from another site nearby (but in an area not yet surveyed by us) in the 14th century.

To the Turkish period, finally, we can assign not only a density of sites, reflecting a further increase in their number, but also a number of surviving monuments, notably water-mills, suggesting that era of relatively stable and efficient garden-agriculture that some of the early travellers saw. This picture, too, almost obliterated by the memory of the devastation and oppression of the closing years of the Tourkokratia, is one to which we hope to add much detail by our future work.

\section{Nonarchaeological Studies}

We wish to say something here of the work being carried out by our colleagues in other disciplines who have been collaborating with us in the expedition. The accounts will be summary, because some of the work is still at an early stage in its progress, while other aspects, as will be noted under the separate headings, have advanced to the point of publication. The work of the expedition was conceived from the start as a cooperative undertaking, in which the archaeological and nonarchaeological studies should not merely complement, but actively assist one another. We on the archaeological side, at least, feel that this aim is being fulfilled and that our understanding of the past history of the landscape has acquired a fresh dimension from the insights of those working on the natural environment and the more recent history of the same district of rural Boeotia. 


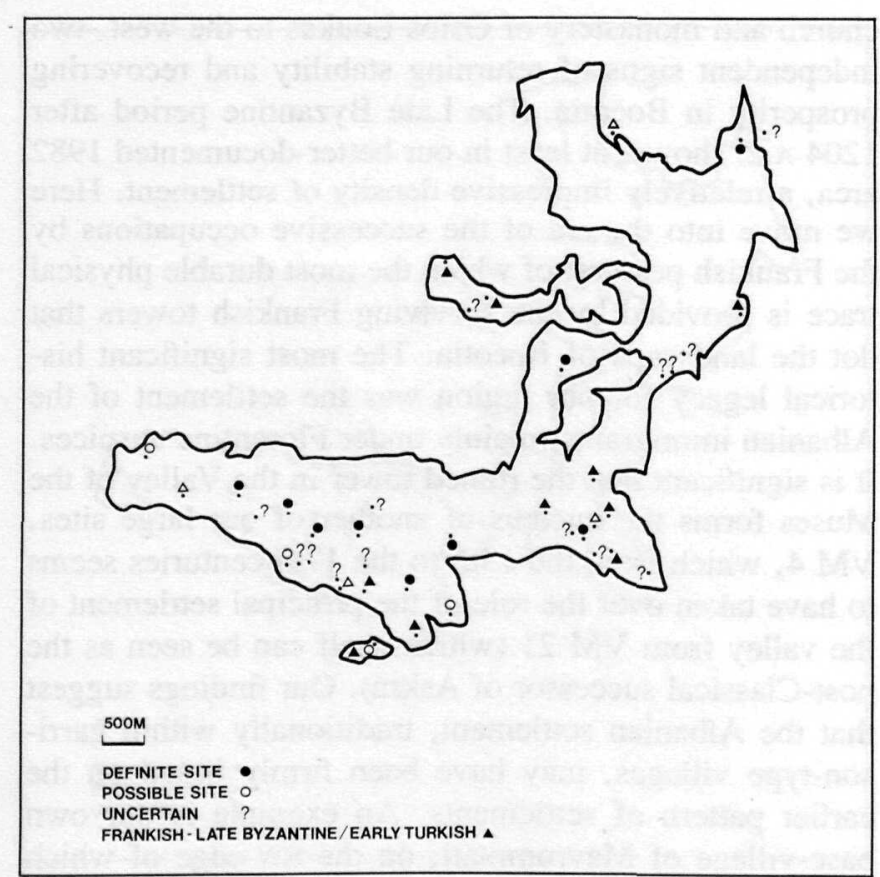

Figure 25. Distribution map: Byzantine sites.

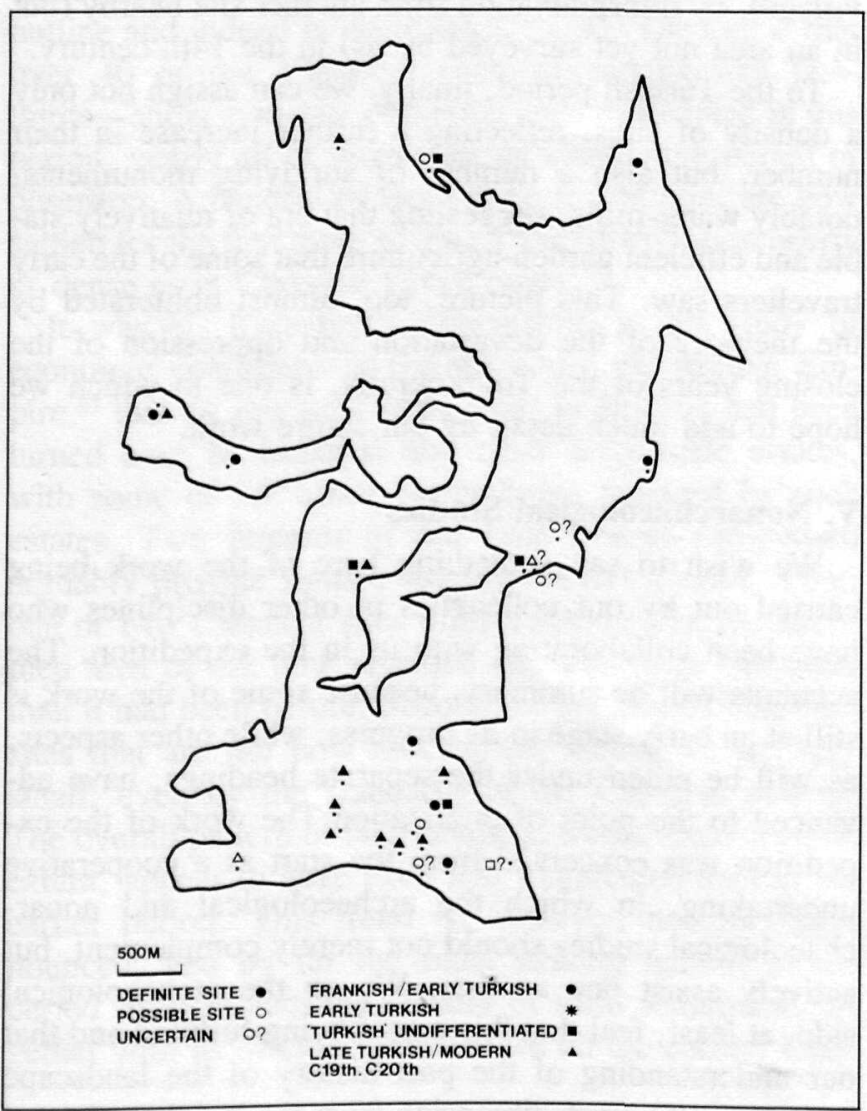

Figure 29. Distribution map: Turkish/Early Modern sites in the eastern area.

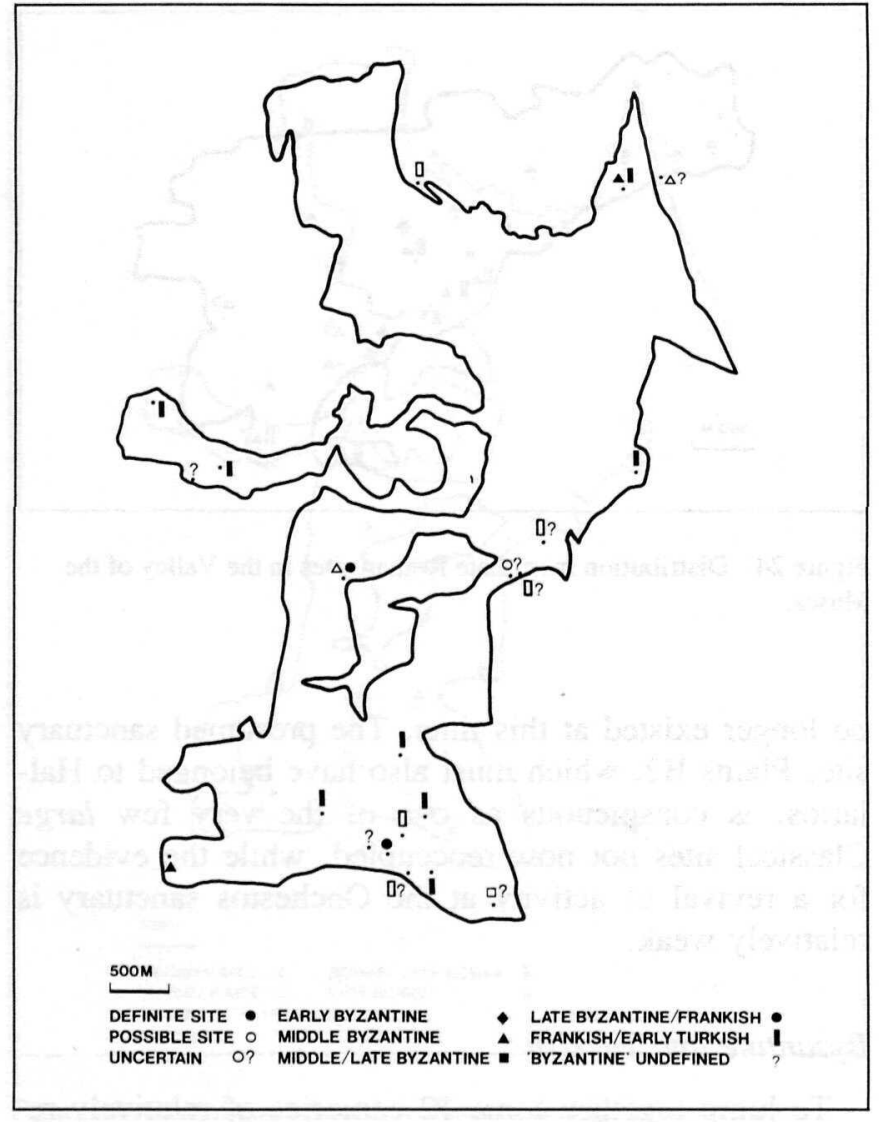

Figure 26. Distribution map: Byzantine sites in the eastern area.

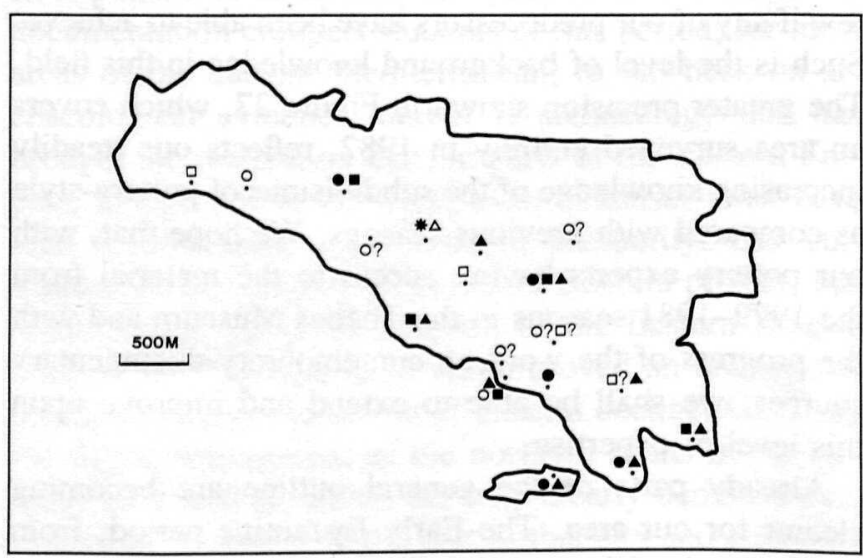

Figure 30. Distribution map: Turkish/Early Modern sites in the Valley of the Muses.

\section{Social Anthropological Aspects}

This account is based on an extended report by C. Slaughter, which we hope will be published in full in a forthcoming number of the Annual of the British School 


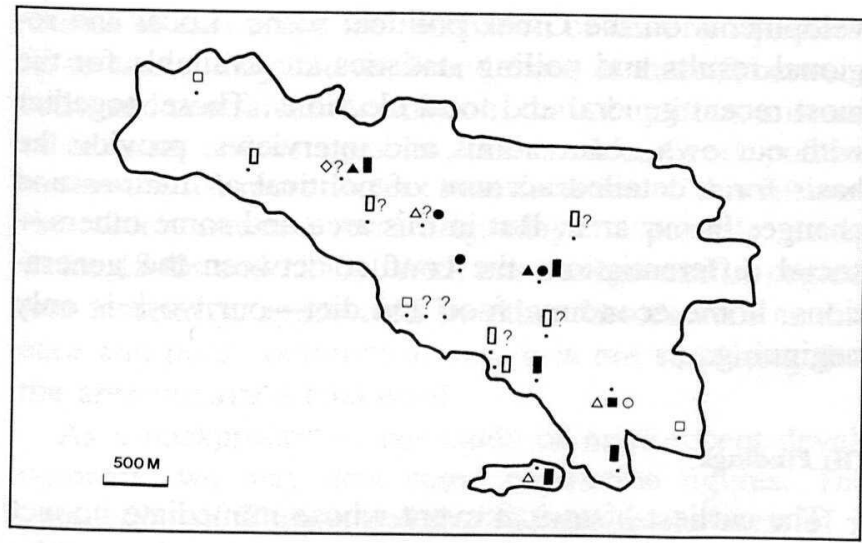

Figure 27. Distribution map: Byzantine sites in the Valley of the Muses.

at Athens. Slaughter participated, as already noted, in our initial reconnaissance of 1978 , when, with the help of his wife Vivien Slaughter (sociologist), he paid preliminary visits to a number of communities within and beyond the ultimate survey area. From 1980 onwards, he was assisted by C. Kasimis, a graduate student of sociology and economics at the University of Bradford, who, at the time of writing and along with other research students, like Kasimis of Greek origin, was taking up aspects of the socioeconomic life of rural Boeotia under Slaughter's supervision. Kasimis' Ph.D. thesis, for which he was awarded the degree in the summer of 1983 , consists in substance of a detailed comparison of one Boeotian community (our headquarters-village of Mavrommati) with another of similar size in the Corinthia (Assos). None of this research could have been carried out without the active assistance of members of the Rural Guard working in the communities under investigation, and especially of $\mathrm{K}$. Hadzidouros of the Thebes office of the Rural Guard.

It is necessary to say at the outset that the present organization and funding of the project, with one month's fieldwork in the summer of each year, are not such as one would normally prescribe for social anthropological field study. A community, and especially one of cultivators and their families, needs to be observed at every point in the calendar. Similarly, the processes of social interaction and their connections with other processes need to be studied for more than a month at a time, if impressions from interview-responses are to be confirmed or corrected by the analysis of actual behavior. For these reasons, the conclusions here reached are to be seen as provisional; and the concentration on the type of material that lends itself to treatment on short and widely-separated visits is a matter of constraint rather than of choice. So, too, the significance of the findings

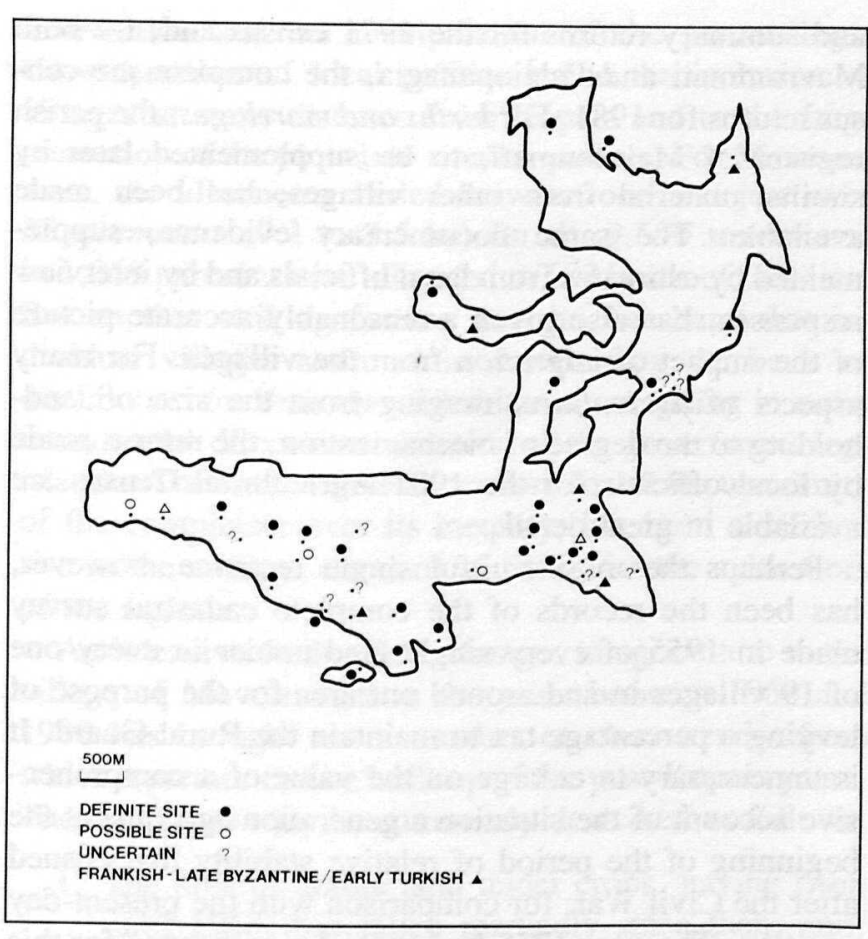

Figure 28. Distribution map: Turkish/Early Modern sites.

for the project as a whole, and for the archaeological work in particular, will not emerge fully until a more comprehensive body of sociological and recent historical material has been assembled. What is offered here is a selection from the evidence so far collected and analyzed.

\section{(A) Sources}

In the years 1979-1982, intensive interview work was carried out in eight villages as well as in Thebes itself. Five of these villages-Mavrommati, Palaiopanagia, Thespiai, Leondari and Neochori-are within or immediately adjacent to the area that has already been surveyed archaeologically, while the others lie slightly further afield. The primary concentration has naturally been on agriculture and land-holding, though factory-managers, professional people, and community leaders have been included. Special emphasis was placed on recording interviews with those old enough to remember preWorld War II conditions.

Some especially useful documentary sources may also be listed here. For the population aspect these include, besides the writings of the early travellers and one or two works of local history, the published reports of the national censuses since 1851 . These in turn have been reinforced by, for Mavrommati, the complete name-list 
and summary returns for the 1971 census and, for both Mavrommati and Palaiopanagia, the complete pre-census returns for 1981. For births and marriages, the parish register of Mavrommati, to be supplemented later by similar material from other villages, has been made available. The same documentary evidence, supplemented by estimates from local officials and by interview responses, has also given a reasonably accurate picture of the impact of migration from the villages. For many aspects of agriculture, ranging from the size of landholding to the degree of mechanization, the returns made by local officials for the 1981 Agricultural Census are available in great detail.

Perhaps the most fruitful single resource, however, has been the records of the complete cadastral survey made in 1955 of every single land-holder in every one of 19 villages in and around our area for the purpose of levying a percentage tax to maintain the Rural Guard. It is unnecessary to enlarge on the value of a comprehensive account of the situation a generation ago, just at the beginning of the period of relative stability that ensued after the Civil War, for comparison with the present-day position. The year 1955 had special significance for this part of Boeotia anyway, for it was then that the distribution of the reclaimed and fertile land of the Kopais basin among the local communities began, the contract of the British Lake Copais Company having expired. Each neighboring village was allocated a portion of the lake area and supervised the apportionment to individuals within its community. There are interesting comparisons to be made, as can well be imagined, among the returns made. In particular, it would be interesting to compare the sizes of land-holdings by the same individuals, but in different contexts (e.g., the 1955 levy or registration for possible allocation of a Kopais plot) and for different purposes (e.g., the applications for loans from the Agricultural Bank of Greece).

For several villages, and in particular for Mavrommati, we have had access to a much larger body of information compiled for the purpose of the annual returns by the community to the Ministry of Agriculture. These relate mainly, but by no means exclusively, to the most recent years, and they cover not only such aspects as land-use, livestock and production, but also the vitally important question of the division between agricultural and nonagricultural occupations. This factor, which really entered the picture only with the opening of a chain of new factories, mostly owned by multi-national companies, along the National Highway near Thebes in the 1960s, has now assumed major proportions: factory buses travel daily to almost every village in the area to carry commuting workers.

The years of our fieldwork have witnessed rapid de- velopments on the Greek political scene. Local and regional results and polling statistics are available for the most recent general and local elections. These, together with our own observations and interviews, provide the basis for a detailed account of political affiliations and changes in our area. But in this area and some otherssocial differentiation, the conflict between the generations, home economy, food and diet-our work is only beginning.

\section{(B) Findings}

The earliest historical event whose immediate impact can still be felt in the communities under study was the importation, by the Catalan Franks, of Albanian mercenaries, beginning with the 20,000 settled in Boeotia by Ramon de Villanova in 1383. The population of most of the villages in the area of Thebes, though not of Thebes itself, is to this day overwhelmingly of Albanian origin, and the language is still to be heard intermittently.

For most purposes, however, a continuous commentary on social conditions begins to be available only in the 18th and 19th centuries, with the fairly detailed descriptions of the early travellers. The recurrent picture that they paint of Boeotia, more insistently as the 19th century progresses, is of a naturally very fertile landscape painfully neglected. There is no doubt that, for generations after independence, the legacy of the Turkish administration, increasingly exploitative and parasitic in its later years, constituted a burden on the cultivator too heavy for an impoverished central government to lift. Few villages in Boeotia could muster even the rockbottom prices at which the estates of the former Turkish landlords were on sale, and much of the country became part of the National Lands. Some part of these lands was sold on favorable terms to ex-soldiers and war-widows, but it is only in 1870-1871 that we first hear of its becoming at all widely available for purchase by cultivators. Boeotia suffered especially for having been an area in which Turkish state property had formerly predominated. Naturally, the Greek cultivators had no legal title to the lands that they worked, and the designation of these properties as National Lands prolonged this state of affairs. The most that the government could do for them, in 1843, was to prevent any land whose cultivators had occupied it "from time immemorial" from being allocated to ex-soldiers.

In other ways, too, the unchanged conditions and continuing ills of the later Turkish administration remained in force for much of the 19th century. The dominant local influence, for example, remained in the hands of those who had served the Turkish rulers in many aspects of trade, finance, and administration. These men 
tended to encourage the usurpation of land by squatters. In so doing, they laid the foundations of that rift between local and central administration, that ubiquitous mistrust of the state and its agencies, that burdens Greek politics to this day. A more violent manifestation of this rift was the widely-attested local brigandage, especially strong in the 1840s and 1850s. With this background of neglect and insecurity, aggravated by other factors such as disease and poor communications, it is not surprising that the area remained backward.

As a background to our study of more recent developments, we may note some population figures. The population of Thebes and the villages to the west of it today stands, in most cases, at over four times the level of the 1851 census. Yet the years since World War II have seen some violent changes of trend. These include an increase of $11 \%$ at Mavrommati in the years between 1951 and 1961, attributable mainly to the effects of the Kopais distribution (see below); a drop of no less than $29.2 \%$ between 1961 and 1971, largely as a result of emigration, both internally and overseas; and then an even more dramatic increase, of over $50 \%$, between 1971 and 1981, a phenomenon at whose main cause we have already hinted in our reference to regional industrialization. This same decade witnessed another striking feature: an influx of wives from Thessaly, who had met their husbands during seasonal employment in our locality.

The British Lake Copais Company had obtained the concession to drain the Kopais basin in 1887, though it was not until 1931 that its work reached final completion. By the latter date, the operations of the Company and the conflict of interests between it and the cultivators who leased the newly-drained land had led to violent clashes and a rent strike. The years of occupation and civil war, from 1941 to 1949, brought widespread damage of crops and installations. After this period of dire poverty to the point of near-starvation in the district, the government in 1953 implemented its legislation to buy out the Lake Copais Company. This was the first event of real significance in transforming the lot of the cultivator in western Boeotia. Thousands of peasant families faced with poverty and emigration suddenly found themselves able to stabilize their existence as farmers; not even the large-scale land distributions of the Venizelos period (in 1917 and 1928) had been able to secure such an effect.

Forty villages shared in the distribution of the Kopais land. The episode, like everything else in the socioeconomic and political life of Greece, has its official and unofficial history. Initially, the land was to be given to the landless cultivators of the adjacent villages; however, stories abound in every village of the inequity of the distribution and the manipulation of the proceedings. Considerations of local politics led to the inclusion of villages at some distance from Kopais and to the fragmentation of the plots into smaller parcels. For Mavrommati, the allotments varied between one and just over 35 stremmata ( 0.1 to $3.5 \mathrm{ha}$ ). In all, 9,550 stremmata, in 1,069 parcels, were allocated to 582 heads of families. But another striking feature was the free hand that individual villages assumed in determining the basis of distribution for their own inhabitants, extending in some cases to the direct contravention of the government legislation. The result of the allocation, for all the unanimity of the complaints over its inequity, has been a marked rise in the average standard of living for the cultivators of the region.

An intensive study of the changes in agriculture in the village of Mavrommati in the years between 1963 and 1980 has brought out a number of clear trends, from which a picture can be built up of the post-Kopais years. These changes may be summarily described as follows:

1. The area of arable land under crops, having risen until 1968, has fallen markedly since then, and, within this category, the irrigated area has fallen even more steeply;

2. The area given over to vines also declined steeply and now remains steady at a relatively low level;

3 . Vegetables and garden crops, though a small component in terms of area, have increased by more than threefold;

4. The much larger area covered by trees (mostly olives) has increased very considerably, mainly between 1973 and 1978;

5. The total area under cultivation, reflecting the sum of these changes, has made a small $(6.4 \%)$ increase over these 17 years;

6. Mechanization has made great advances in this period: at Mavrommati, for instance, the number of tractors rose from 13 to 110 , whereas the number of farm animals fell from 340 to 100 .

These overall changes conceal a number of internal shifts of emphasis, and invite certain glosses of detail. Thus, concerning the first change, we may note that there has been a major shift from cotton to wheat and an increase in clover at the marked expense of barley and maize. These changes are in part explained by the growing attraction of crops that provide an easier and less time-consuming alternative for people employed outside agriculture. The issues are, however, greatly complicated by the problems of irrigation. The increased water-consumption of Athens (which draws much of its supplies from Boeotia) and a period of exceptionally low rainfall in the 1970 s and early 1980 s have produced 
something of a water crisis: the level of the water-table reached by drilling has dropped very markedly. The average cost of a drilling is high, and there is no doubt that this has become a factor for economic differentiation within the peasantry, besides causing the fall in the irrigated area that has been noted. An explanation of the second change in trend lies in the outbreak of the disease phylloxera, which affected the whole area in the 1960s and early 1970s. The most important feature of the third change has been the introduction of large-scale tomatogrowing, particularly in the Kopais lands, in the early 1970s. Concerning the fourth change, it is notable that although there has been a large relative increase in the growing of almonds and walnuts, the main factor has been the $46 \%$ increase in the number of olive-trees, from 65,000 to 95,000 , over this period. The severe damage which these trees suffered in the winter of 1980-1981, however, is not covered by these figures.

The sixth major change in trend, advances in mechanization, is a phenomenon whose beginnings lie in the decade of mass-emigration in the 1960 s, leading to a shortage of agricultural labor. The necessary capital emerged, partly through the increase in state agricultural subsidies through the Agricultural Bank of Greece and partly by the funds remitted to their homelands by the now-prosperous emigrés. Manufacturers of machinery, too, were eager to expand into the agricultural market. Besides tractors, these years have seen a sharp increase in other forms of machinery, particularly pumps and sprinklers. The factor of regional industrialization, referred to already, has had its effect here too, by creating a new type of part-time cultivator and, less directly, by facing the peasant with the stark choice, either of modernizing his holding or of deserting it altogether in favor of industrial employment. Today, the high-powered tractor (often far larger than is justified by the size of holding being worked) has become something of a status-symbol in the agricultural villages.

On social structure, we offer some general observations, supported by our specific investigations of the developments in land-holding since the Kopais distribution. The population of Greece has doubled in the last 60 years. At the same time, the proportion of this population living in rural areas has fallen from $82 \%$ a century ago to about $25 \%$ today, giving a substantial reduction in absolute terms. These overall figures mask some very pronounced regional and local differences, particularly in the matter of the depth of attachment to the land. Within our area, for instance, the villages of Mavrommati and Vagia show a very much higher correlation of land-ownership with residence, and/or father's residence, in the village than do Palaiopanagia and Xiron- omi. The proportion of land with absentee owners (living, in most cases, in Athens) is only about $5 \%$ in the first two places; in Xironomi it is over $30 \%$.

Yet it would be a serious mistake to interpret the pattern at Mavrommati and Vagia along the lines that most laymen and some professionals would probably favor: that is, to see it as the persistence of some kind of traditional order, of an age-old attachment to community land. Our investigations suggest that the truth is almost the opposite. A century ago, at the limit of what our oldest interviewees can recall of their family histories, there was much more selling of land as a consequence of indebtedness, poverty, or sickness. It is the appearance of the modern sources of income, notably other occupations and emigration, that has served to increase the attachment to the land. It is for reasons of local geography that these modern factors have been more influential in Mavrommati and Vagia than in the slightly remoter villages to the south and west.

Many of our findings have been based on the laborious tracing of a stratified sample, amounting to 160 individuals, extracted from the records of the 1955 levy survey and then followed through the subsequent 25 years. Here, in the matter of social stratification by wealth, a clear conclusion, parallel to the one for land-ownership just mentioned, has already emerged: it is the result of recent differentiation and not a matter of descent from the traditionally better-off families. The prevalence of a system of inheritance that involves division of property among sons and proika (dowry) for daughters has naturally tended to reinforce the process. In the same way, in the past, this system militated against the survival of long-standing attachment to the land, given the fact that there is no tradition of endogamy in these villages. Many examples could be given of the kinds of enterprise, ranging from sheep- and goat-herding to selling sweets from a bicycle trolley, that have formed the basis of this recent wealth.

One other characteristic feature of Greek agriculture that must not be passed over is the fragmentation of holdings - the fact that, typically, a holding of 3-5 ha will comprise five, or even 10 , pieces of different sizes in randomly-distributed parts of the village lands. Attitudes on this issue are baffling and contradictory. Although all parties are agreed that the system of inheritance is entirely responsible for the situation, and although there is almost unanimous agreement that, in principle, it would be better if cultivators could obtain accretions of land immediately adjoining their existing plots, there is in practice a deep-seated resistance to any proposal for such rationalization. This was shown by the failure, some years ago, of a project to carry out such 
concentration at Vagia. The dominant spirit seems very close to that revealed in many studies of the Italian South: a kind of competitive individualism and hostility to the success of others. This once operated at the level of the struggle for mere existence but is now applied to a situation where there are possibilities for relative affluence.

Many of the factors already noted-the existence of alternative employment and the possibility of emigration, the system of inheritance, the forms of support and credit available through the Agricultural Bank, and no doubt the underlying attitude of fthonos (envy) itselfhave combined to produce a further effect: the absence of any really large farms. Even a holding of 50 acres is altogether exceptional. The full explanation of this feature is obviously a complex matter. There is a widespread view among our informants, however, that, within the constraints of the availability of labor and the need for personal supervision, such a size represents the upper limit of effective operation for a farmer and his family. Once again, the attractions of other ways of supplying the family's subsistence are greater than those of accumulating further land. Insofar as any real capitalization in agriculture has taken place, it is on the part of a small minority of the larger land-owners. Such capitalization takes the form not of extended ownership, but of the acquisition (usually very recent) of expensive machinery that can be hired out and of the use of capital to rent the land of others and hire seasonal labor.

A few selected figures will give a basis for some of these generalizations. In the villages of Leondari, Neochori, and Mavrommati, the number of holdings originally in the possession of our stratified sample of 160 individuals has increased by $63 \%$ in the subsequent 25 years; whereas the average size of holding has decreased by $45 \%$, invariably as the result of sale, partible inheritance, or proika (dowry). The number of holdings worked by those with non-agricultural primary occupations has, in the same period, increased from $8.6 \%$ to $52.2 \%$, but this increase is not distributed evenly across the range of size of holdings. On the contrary, in the case of Mavrommati, at least, we find a remarkably steady gradation. In 1981, among the holdings of 10 stremmata or less, the proportion of owners with other primary occupations is $100 \%$. This proportion then falls evenly as the size of holding increases, until it reaches nil for holdings of over 100 stremmata.

However much the further research of ourselves and others may refine and extend these finds, the conclusion (however paradoxical) is already clear; the changes of the last generation have, at least for the time being, reinforced the structure of small-scale farm ownership.

\section{Ethnological Aspects}

Nancy Stedman, a research student of the University of Bradford under the supervision of Bintliff, began her work with a stay of six weeks in Greece in 1982, partly in Athens and partly with us in the field. She has carried out an intensive study of travellers' accounts of Boeotia, from George Wheler (1689) to Sir James Frazer (1919). The subjects treated will include routes, roads, and roadsurfaces; vernacular architecture (with particular attention to Mavrommati and Palaiopanagia); recent changes of settlement-location in the area of the Valley of the Muses; relations between Greek and Turk during the Tourkokratia; and the extent of cultivation and rural habitation in the period covered by the travellers' accounts. Stedman will continue to work on village patterns and field-systems since late Medieval times and on the evidence (including that of surviving remains) for rural industry. The relevance of her findings to the later periods covered by the archaeological survey will be obvious.

\section{Vegetation History}

Since O. Rackham's 25,000-word paper, "Observations on the Historical Ecology of Boeotia," has now been published in volume 78 (1983) of the Annual of the British School at Athens, we merely refer here to the appearance of that article, which is based on several weeks of fieldwork he undertook with us, mainly during the 1979 and 1980 seasons, with a shorter visit in 1981 .

\section{Palynology and Palaeobotany}

Margaret Atherden, who also worked with us (and more especially in collaboration with Rackham) in the seasons 1979-1981, has worked on the environmental context of the various archaeological periods under investigation by the expedition. She undertook a search, over a dozen locations in Boeotia, for suitable sites from which to obtain pollen-diagrams, to supplement that published by Greig and Turner in 1974, from Lake Kopais. In the face of very considerable difficulties-lack of peat deposits, poor preservation of pollen, and wildly fluctuating levels in the Boeotian lakes, to name but a fewonly a single coring site in the bed of Lake Paralimni produced sediments with countable amounts of pollen. The results here show a distinct correspondence with those from the published Kopais core, with two separate phases of olive cultivation and a steady increase in maquis elements in (relatively) recent levels. But the main need for the future must be to obtain a better-preserved organic deposit, preferably with the addition of $\mathrm{C}^{14}$ dates 


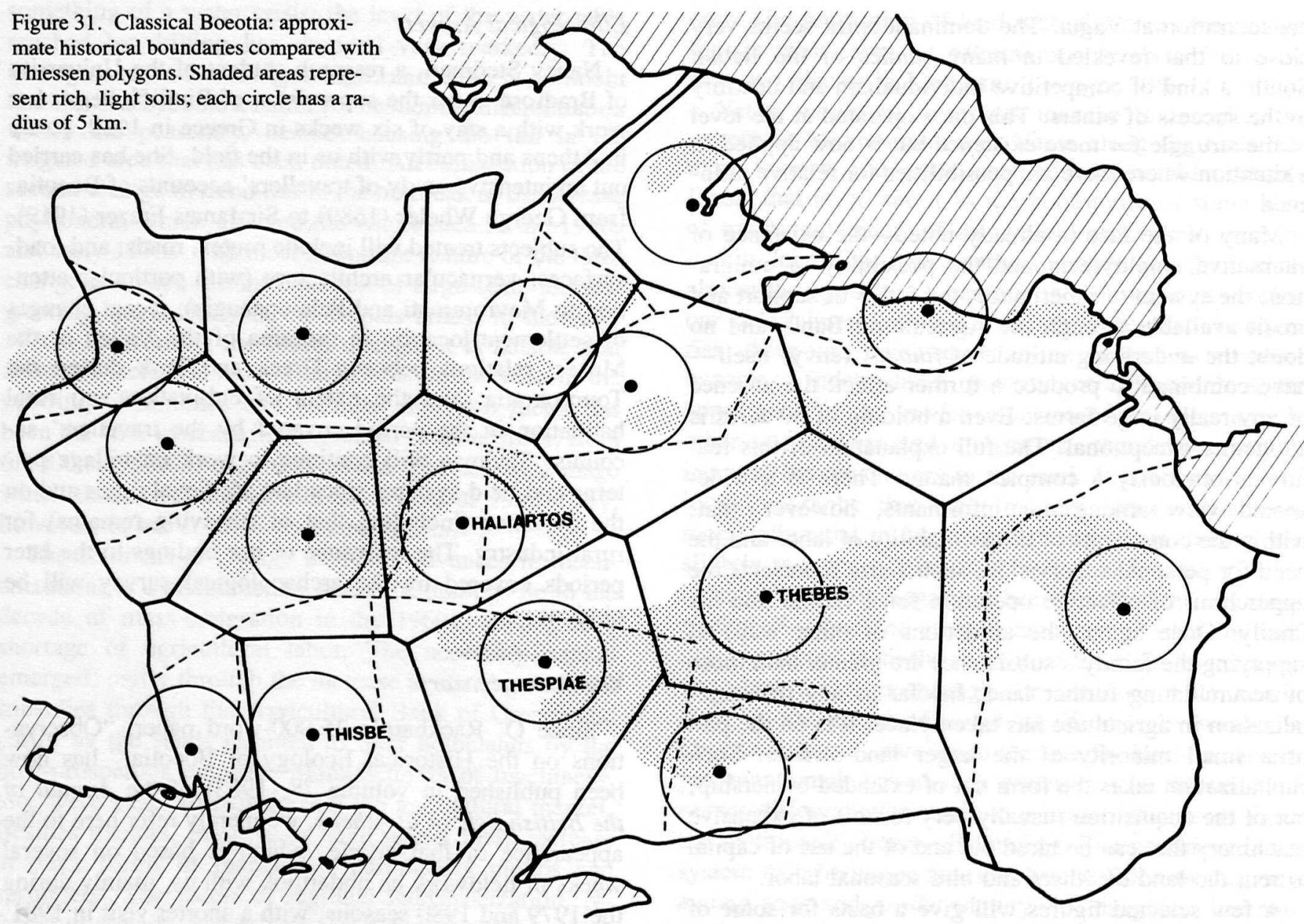

to give a framework of absolute dates. In this connection, we should refer to our prospective collaboration with a geographical project initiated by A. T. Grove of the University of Cambridge. In 1982 three of Grove's undergraduate students worked under our general guidance on early shore-lines and geological sections round the edge of Lake Kopais. In 1983 and future years, a graduate student plans to carry out fulltime study of this area with a view to possible lake coring: she herself would then study the sediments, and Atherden the pollen obtained from such cores.

\section{Geophysical Site Survey}

K. Maude of the University of Manchester, who has worked with us every season so far, has examined 14 of our sites by electrical resistivity methods. He has produced a detailed study of the results from four of thesetwo small, presumed farmstead sites, a medium-sized site (Plains B3) of long occupation, and the huge 1981 site, Plains A5-with plots coordinating the resistivity contours and the sherd-densities. All four sites produced strong anomalies that could be interpreted as buried archaeological features, but in three of the sites these anomalies coincided not with the highest sherd-concentrations, but with areas of lower density close beside these peaks. It is possible that the peaks in sherd density may prove to represent midden or pit areas immediately beside buildings, a hypothesis that Maude hopes to test by blanket coverage of a small farmstead site.

\section{Site Planning}

P. W. Lock of the College of Ripon and York St. John has, during the past three seasons, been drawing contoured plans by means of plane-tabling of each of the sites located by us.

\section{Future Work}

A clear need, now that our field procedures have 


\begin{tabular}{|c|c|c|c|c|}
\hline \multirow{2}{*}{\multicolumn{2}{|c|}{ Palaeolithic }} & Definite* & Possible & Unclear $\neq$ \\
\hline & & 0 & 0 & 2 \\
\hline \multicolumn{2}{|c|}{$\begin{array}{l}\text { Cumulative: Later Prehistoric } \\
\text { (Final Neolithic to Geometric) }\end{array}$} & 13 & 2 & 12 \\
\hline \multirow[t]{6}{*}{ Specific*: } & Final Neolithic/Early Helladic & 2 & 0 & 1 \\
\hline & Early Helladic & 3 & 2 & 2 \\
\hline & Middle Helladic & 9 & 0 & 0 \\
\hline & Late Helladic & 8 & 1 & 6 \\
\hline & Late Helladic/Dark Age & 0 & 2 & 0 \\
\hline & Geometric & 2 & 2 & 2 \\
\hline \multicolumn{2}{|c|}{ Cumulative: Archaic to Early Hellenistic } & 69 & 4 & 4 \\
\hline \multirow[t]{4}{*}{ Specific: } & Archaic & 5 & 8 & 10 \\
\hline & Classical & 21 & 49 & 5 \\
\hline & Classical/Early Hellenistic & 43 & 3 & 3 \\
\hline & Early Hellenistic & 6 & 56 & 4 \\
\hline \multicolumn{2}{|c|}{ Cumulative: Late Hellenistic to Roman§ } & 32 & 8 & 10 \\
\hline \multirow[t]{4}{*}{ Specific: } & Late Hellenistic & 9 & 17 & 5 \\
\hline & Late Hellenistic/Early Roman & 10 & 5 & 5 \\
\hline & Early Roman & 14 & 23 & 11 \\
\hline & Roman undifferentiated & 7 & 1 & 2 \\
\hline Specific: & Late Roman & 45 & 4 & 5 \\
\hline \multicolumn{2}{|c|}{ Cumulative: Byzantine/Frankish } & 9 & 17 & 14 \\
\hline \multirow[t]{4}{*}{ Specific: } & Early Byzantine & 0 & 0 & 1 \\
\hline & Middle Byzantine & 4 & 5 & 4 \\
\hline & Late Byzantine/Frankish & 5 & 12 & 8 \\
\hline & Frankish/Early Turkish & 11 & 4 & 7 \\
\hline \multicolumn{2}{|c|}{ Cumulative: Turkish/Early Modern } & 23 & 11 & 8 \\
\hline \multirow[t]{2}{*}{ Specific: } & Early Turkish & 1 & 12 & 4 \\
\hline & $\begin{array}{l}\text { Turkish undifferentiated } \\
\text { Late Turkish/Early Modern }\end{array}$ & $\begin{array}{r}9 \\
18\end{array}$ & $\begin{array}{l}2 \\
2\end{array}$ & $\begin{array}{l}3 \\
1\end{array}$ \\
\hline Specific: & Modern (20th century) & 31 & 1 & 1 \\
\hline \multicolumn{5}{|c|}{$\begin{array}{l}\text { *The totals under "Specific: Definite" are non-overlapping; that is, the category "Classical/ } \\
\text { Early Hellenistic," for example, is treated as additional to the categories "Classical" and } \\
\text { "Early Hellenistic." }\end{array}$} \\
\hline \multicolumn{5}{|c|}{$\dagger$ That is, with material definitely of this period, but in small quantity. } \\
\hline \multicolumn{5}{|c|}{$\begin{array}{l}\ddagger \text { That is, with material which, irrespective of its quantity, is only questionably of this } \\
\text { period. }\end{array}$} \\
\hline & ate Roman. & & & \\
\hline
\end{tabular}

Table 6. Site summary, 1979-1982

(latest pottery studies in 1983). become more streamlined, is for us to accelerate our coverage of the landscape, without any loss in intensity. In particular, we shall now be broaching terrain with a different historical significance: the urban nucleus of ancient Thespiai itself and a more substantial portion of the territory known to have belonged to Haliartos (FIG.
31). The supporting research (apart from that on vegetation history, which is complete) will be simultaneously pursued. High priority will be given to the coordination of the archaeological findings for the Turkish period with Stedman's study of the documentary and other sources, which seems to us to offer unique possibilities for testing 
Table 7. Table of sites and periods.

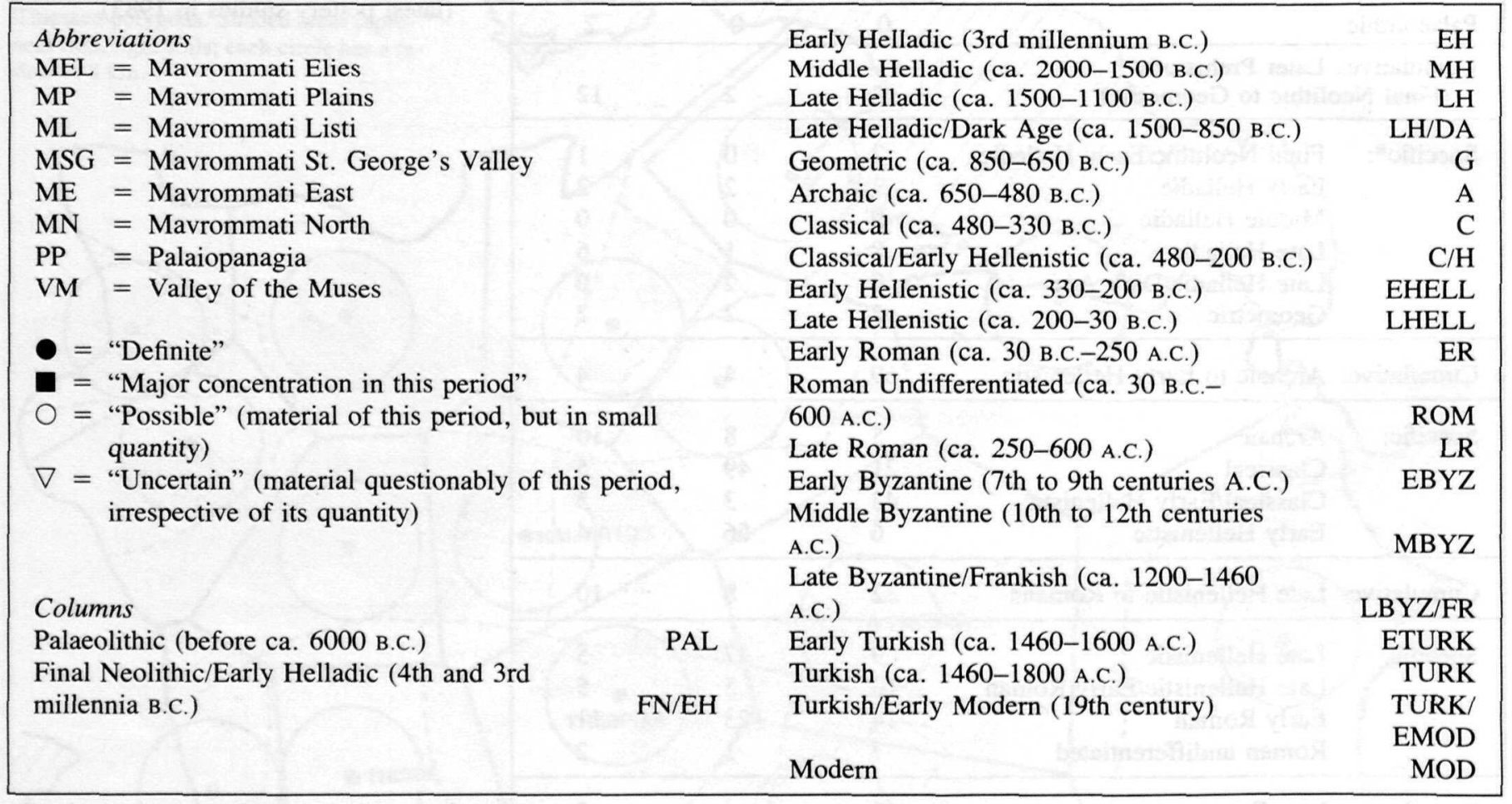

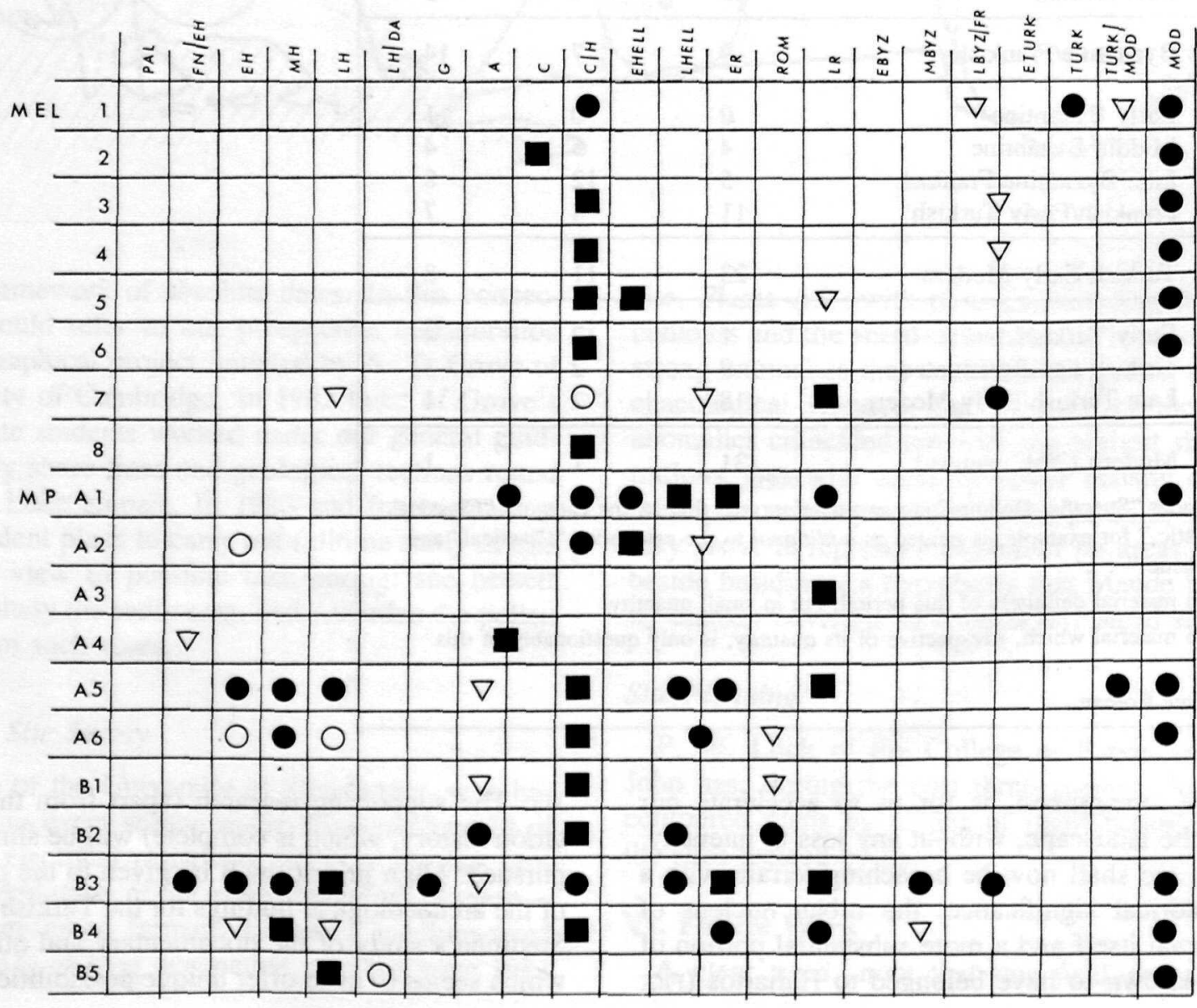



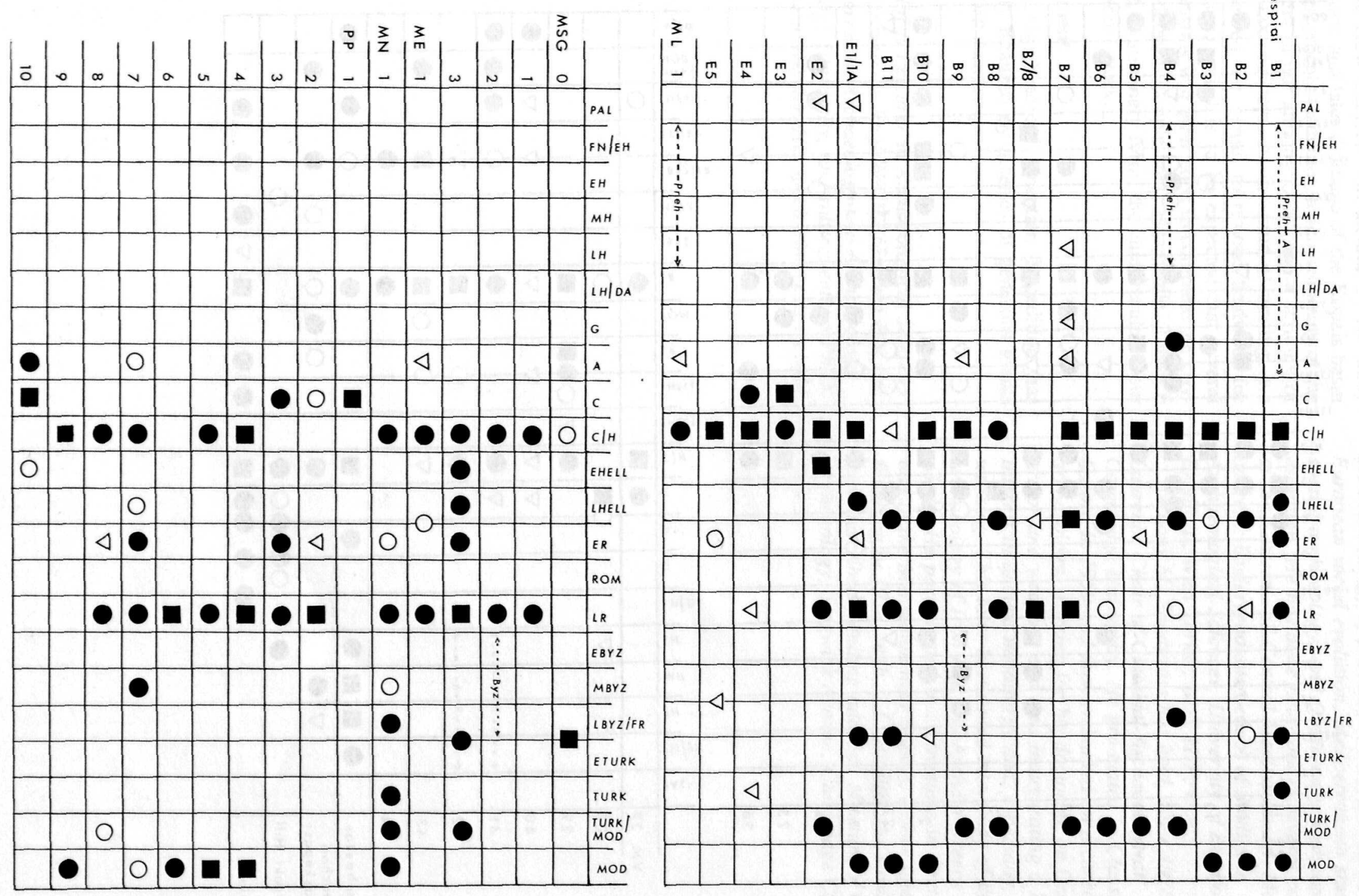
Table 7. (cont.)

\begin{tabular}{|c|c|c|c|c|c|c|c|c|c|c|c|c|c|c|c|c|}
\hline 13 & & & & & & 0 & $\square$ & & $\bullet$ & & & & 0 & 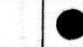 & 口 & 0 \\
\hline 14 & & & & & & 0 & $\square$ & & $\infty$ & & 0 & & $\infty$ & $\nabla$ & a & 0 \\
\hline $\begin{array}{ll}M & 1\end{array}$ & $\cdots$ & ..Pre & eh.. & $\cdots$ & & & 0 & & 0 & & $\boldsymbol{\square}$ & & 1 & & & 0 \\
\hline 2 & & & & 0 & & - & 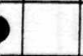 & 0 & 7 & & 0 & & 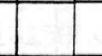 & 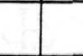 & 0 & \\
\hline 3 & & & & & & 0 & 0 & & 00 & 0 & $\square$ & & 0 & 0 & & \\
\hline 4 & & - & - & 口 & & 0 & 0 & & †० & & 0 & $\nabla$ & D & च & 0 & \\
\hline 5 & & & & & & $\square$ & & & & & & & & & 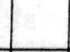 & \\
\hline 0 & & 인 & 0 & $\nabla$ & & 0 & 1 & & $0 \nabla$ & 0 & E & & 0 & & 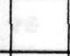 & \\
\hline 21 & & & - & - & & 0 & 0 & & 0 & & च & - & 1 & $\bullet$ & $\bullet$ & 0 \\
\hline 22 & & & & $\nabla$ & & 0 & & & 00 & & - & $-8 y_{z}$ & $(\cdots)$ & & 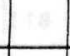 & $\nabla$ \\
\hline 23 & & & & & 0 & & $\bullet$ & & 0 & $\bullet$ & - & $\therefore-8 y z$ & $\cdots$ & E & 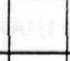 & \\
\hline 24 & & & & & & & 0 & & & - & & & 0 & 0 & $\bullet$ & \\
\hline 25 & & & & & & & 口 & & & - & - & & & & & \\
\hline 26 & & & & & & & - & & 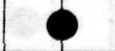 & & - & & $\nabla$ & & & \\
\hline
\end{tabular}

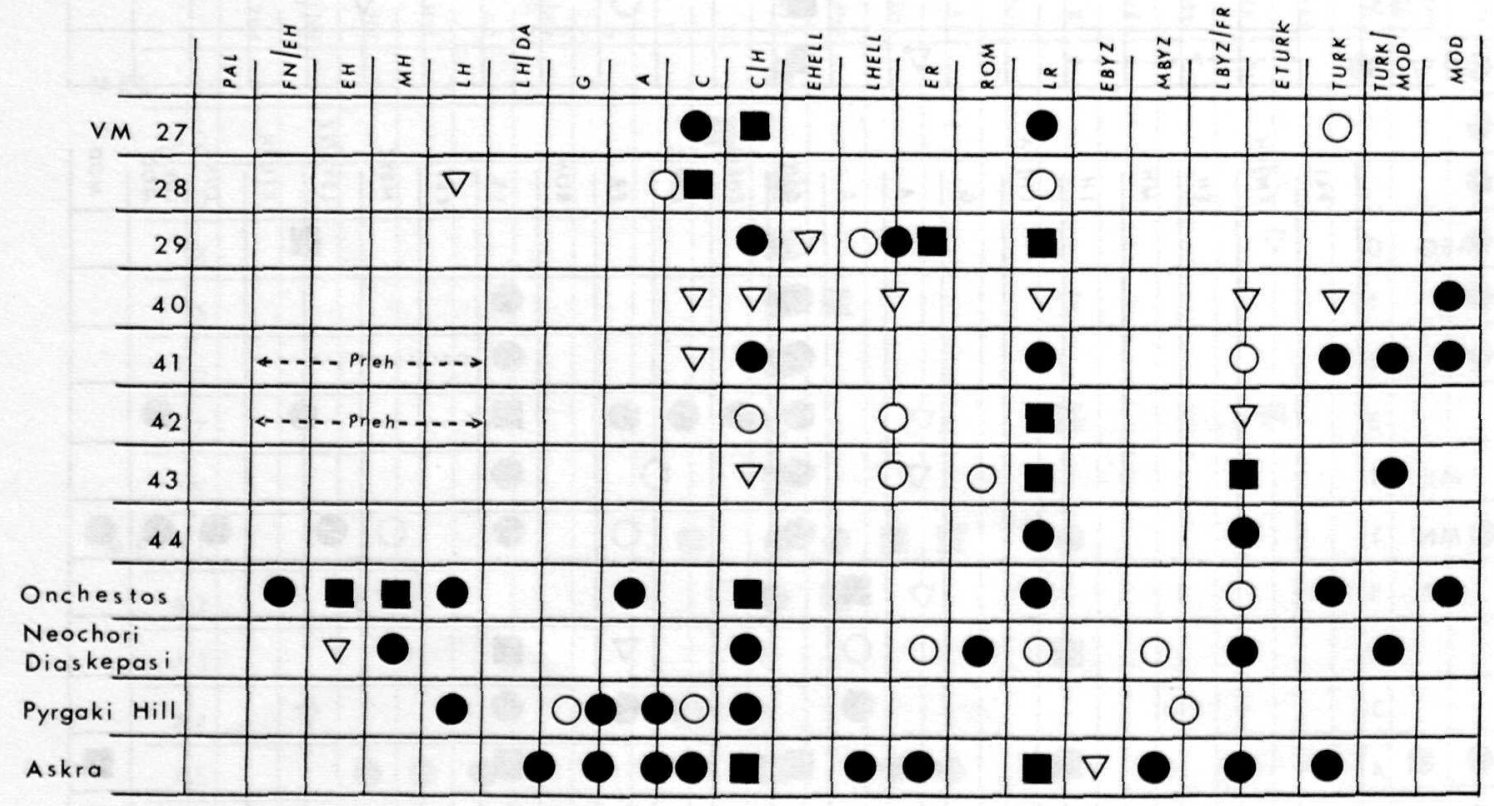


and validation. New elements will include a fresh study of the prehistoric and later drainage of the Kopais basin from the geographical standpoint, a detailed study of the Frankish towers in our area by Lock, and a scrutiny of the Ottoman tax registers. At the time of writing, we have just received our permit to resume fieldwork for the 1984 season, and it is to be expected that several subsequent seasons will be needed to complete our coverage of an adequate sample area. Meanwhile, Tables 6 and 7 present, in summary form, the chief results of our first four seasons' work.

\section{Acknowledgment}

The Cambridge/Bradford Boeotian Expedition has been primarily financed by a series of generous grants from the British Academy.

John L. Bintliff is Lecturer in Archaeological Sciences at Bradford University, England. He received B.A. and M.A. degrees in Archaeology and Anthropology from Cambridge University, and subsequently a Ph.D. from the same university. His special interests include the archaeology of prehistoric to modern Greece, European social evolution, Mediterranean studies, spatial archaeology, and Quaternary landscape evolution. He has done fieldwork in several countries of the Eastern and Central Mediterranean. Mailing address: Undergraduate School of Studies in Archaeological Sciences, University of Bradford, Bradford, West Yorks., BD7 1DP, U.K.

Anthony M. Snodgrass has held, since 1976, the Laurence Chair of Classical Archaeology at Cambridge University. He graduated in Classics at Oxford in 1959 and then embarked on a career in archaeology, working for his doctorate on Greek armor and weapons and thus inaugurating a lasting interest in ancient metallurgy and, especially, ironworking. This later broadened into study of the archaeology of Iron Age and Archaic Greece as a whole. He participated in excavations in Crete, Sicily, and at the Menelaion near Sparta, before jointly founding in 1978, with J. L. Bintliff, the survey project here described. Mailing address: Museum of Classical Archaeology, Sidgwick Avenue, Cambridge CB3 9DA, U.K. 